WSRC-TR-2001-00155, Rev. 1

\title{
THERMODYNAMIC MODELING OF THE SRS EVAPORATORS: PART II. THE 3H SYSTEM (U)
}

C. M. Jantzen, J. E. Laurinat, and K.G. Brown

April 8, 2002

TTP \#: SR-1-9-WT-31, Subtask A.2-2

Approved by:

W.L. Tamosaitis, Research Manager

Waste Processing Technology 
This document was prepared in conjunction with work accomplished under Contract No. DEAC09-96SR18500 with the U.S. Department of Energy.

\section{DISCLAIMER}

This report was prepared as an account of work sponsored by an agency of the United States Government. Neither the United States Government nor any agency thereof, nor any of their employees, makes any warranty, express or implied, or assumes any legal liability or responsibility for the accuracy, completeness, or usefulness of any information, apparatus, product or process disclosed, or represents that its use would not infringe privately owned rights. Reference herein to any specific commercial product, process or service by trade name, trademark, manufacturer, or otherwise does not necessarily constitute or imply its endorsement, recommendation, or favoring by the United States Government or any agency thereof. The views and opinions of authors expressed herein do not necessarily state or reflect those of the United States Government or any agency thereof.

This report has been reproduced directly from the best available copy.

Available for sale to the public, in paper, from: U.S. Department of Commerce, National Technical Information Service, 5285 Port Royal Road, Springfield, VA 22161

phone: (800) 553-6847

fax: (703) 605-6900

email: orders@ntis.fedworld.gov

online ordering: http://www.ntis.gov/support/index.html

Available electronically at http://www.osti.gov/bridge

Available for a processing fee to U.S. Department of Energy and its contractors, in paper, from: U.S. Department of Energy, Office of Scientific and Technical Information, P.O. Box 62, Oak Ridge, TN 37831-0062

phone: (865)576-8401

fax: (865)576-5728

email: reports@adonis.osti.gov 
WSRC-TR-2001-00155, Rev. 1

WSRC-TR-2001-00155, Rev. 1

Distribution Category: Unlimited

Keywords: Evaporator, activity diagrams, zeolite

Retention: Permanent

\section{THERMODYNAMIC MODELING OF THE SRS EVAPORATORS: PART II. THE 3H SYSTEM (U)}

C. M. Jantzen, J. E. Laurinat, and K.G. Brown

Publication Date: April 8, 2002

TTP \#: SR-1-9-WT-31, Subtask A2.2

Approved by:

W.L. Tamosaitis, Research Manager

Waste Processing Technology 


\section{Approvals}

C. M. Jantzen, Author, Immobilization Technology

Date

J. E. Laurinat, Author, Actinide Technology

Date

K.G. Brown, Author, Immobilization Technology

Date

M. E. Denham, Technical Reviewer, Environ. Sci. \& Technology

Date

D.T. Hobbs, Technical Reviewer, Waste Processing Technology

Date

Joseph F. Ortaldo, Technical Reviewer, WD Engineering

Date

E.J. Freed, Technical Reviewer, CST Engineering

Date

R.H. Spires, Manager, Immobilization Technology

Date

A. M. Murray, Manager, Actinide Technology

Date

W.L. Tamosaitis, Manager, Waste Processing Technology

Date 


\section{WSRC-TR-2001-00155, Rev. 1}

\section{EXECUTIVE SUMMARY}

Accumulations of two solid phases (a nitrated aluminosilicate, known as nitrated cancrinite and/or nitrated sodalite depending on the number of attached water molecules, $\mathrm{Na}_{8} \mathrm{Al}_{6} \mathrm{Si}_{6} \mathrm{O}_{24}\left(\mathrm{NO}_{3}\right)_{2} \bullet 4 \mathrm{H}_{2} \mathrm{O}$, and sodium diuranate, $\left.\mathrm{Na}_{2} \mathrm{U}_{2} \mathrm{O}_{7}\right)$ have been forming in the Savannah River Site (SRS) 2H Evaporator system since late 1996. The aluminosilicate scale deposits caused the SRS $2 \mathrm{H}$ Evaporator pot to become completely inoperable in October 1999. Accumulation of the sodium diuranate phase, which appears to have simultaneously precipitated with the aluminosilicate phase, has caused criticality concerns in the $2 \mathrm{H}$ Evaporator. In order to ensure that similar deposits are not forming in the SRS $3 \mathrm{H}$ Evaporator, thermodynamically derived activity diagrams specific to the feeds processed from the $3 \mathrm{H}$ Evaporator feed tank (Tank 32) were evaluated.

Reactive oxides, soluble silicates, and soluble aluminates in a caustic solution can combine to form a sodium aluminosilicate (NAS) hydrogel at ambient temperature when the solution stoichiometry of the constituent aluminate and silicate species is $\sim 1: 1$. The hydrogel converts to Zeolite- $\mathrm{A}\left(\mathrm{Na}_{12} \mathrm{Al}_{12} \mathrm{Si}_{12} \mathrm{O}_{48} \bullet 27 \mathrm{H}_{2} \mathrm{O}\right)$ under hydrothermal conditions at elevated temperature such as the conditions existing in the SRS evaporators. It has been shown that the nitrated-cancrinite/sodalite forming in the SRS 2H Evaporator forms from Zeolite-A. Zeolite-A and hydroxysodalite $\left(\mathrm{Na}_{8}\left[\mathrm{Al}_{6} \mathrm{Si}_{6} \mathrm{O}_{24}\right](\mathrm{OH})_{2} \bullet 1.5 \mathrm{H}_{2} \mathrm{O}\right)$ formation from a gel phase has also been observed in evaporators used in the wood pulp industry and Zeolite- $\mathrm{A} \rightarrow$ sodalite $\rightarrow$ cancrinite $\left(\left(\mathrm{Na}_{7.6} \mathrm{Al}_{6} \mathrm{Si}_{6} \mathrm{O}_{24}\left(\mathrm{CO}_{3}\right)_{1.6} \bullet 2.1 \mathrm{H}_{2} \mathrm{O}\right)\right.$ formation have been observed in the Bayer aluminum fabrication process.

The sequential transformations of NAS gel $\rightarrow$ Zeolite-A (cubic) $\rightarrow$ sodalite(cubic) $\rightarrow$ cancrinite (hexagonal) are densification (aging) transformations that require the saturation of the evaporator and/or tank solutions with respect to the parent NAS gel phase. Modeling the potential to form the NAS gel phase in the feed or drop tanks and/or in the evaporator has been chosen because this phase is the primary phase from which all the others are derived and it is kinetically most rapid step in the formation sequence [aluminosilicate species in solution] $\rightarrow$ NAS gel $\rightarrow$ Zeolite-A $\rightarrow$ sodalite $\rightarrow$ cancrinite. Modeling the denser phases, which are less soluble than the NAS gel, could unnecessarily constrict the solution chemistry range of the SRS evaporators.

The current SRS 3H Evaporator pot has been in operation since May 2000. The $3 \mathrm{H}$ Evaporator feed tank is Tank 32 and the drop tank is Tank 30. Tank 32 has received multiple recycles of supernate from the drop tank (Tank 30) on a 4-6 week frequency. Typically during a recycle transfer from Tank 30 to Tank 32, the evaporator continues being fed. Tank 32 also received a transfer from Tank 40 of Extended Sludge Processing (ESP) Washwater in December 2000. Tank 32, the feed tank, has about 48" of sludge at the bottom. The transfer pump to the evaporator is located at a height of 89 " from the bottom of the tank. Tank 30, the drop tank, reportedly has no sludge at the bottom. Tank 30 had a transfer jet that was located 4" above the bottom of the tank during the time period that this study covers. ${ }^{\dagger}$ The $3 \mathrm{H}$ Evaporator has been operating at $135-140^{\circ} \mathrm{C}$ since

\footnotetext{
$\dagger$ In the spring of this year, the fixed length transfer jet was replaced with a telescoping transfer jet (TTJ) which is currently positioned 150 " from the tank bottom.
} 


\section{WSRC-TR-2001-00155, Rev. 1}

May 2000. Tanks 32 and 30 have been at a nominal temperature of $\sim 40^{\circ} \mathrm{C}$ until a few months ago when cooling coil difficulties caused the temperature in Tanks 30 and 32 to become elevated.

The historical chemical data for the feed tank (Tank 32) had been taken at various times between November 1992 and February 2001 and at various depths. The chemistry of the variable depth samples (VDS) indicates chemical zones exist within the tank at different depths. Three depth populations were defined:

- Surface dip sample analyses (surface to 120 " from the tank bottom)

- Variable Depth Sample (VDS) analyses (70 to 120" from the tank bottom, e.g. 30" above the feed pump and 20" below the feed pump)

- "Zone of Turbidity" (ZOT) analyses (>48" to <70" from the tank bottom, e.g. the surface of the sludge to the next available chemical analysis)

Turbidity in the ZOT is caused by the following:

- turbulent eddies of sludge stirred up when recycle transfers are injected below the sludge surface every 4-6 weeks

- influence from feed pump turbulence $\sim 20$ " above

- hydrophobic silica rich sol accumulation layer, e.g. a layer which will not settle because silica sols are hydrophobic and repel each other

Feed from the ZOT cannot be pumped into the evaporator since the feed pump is $>20$ " above the upper boundary of the ZOT. Therefore, no modeling was performed on samples from the ZOT.

The historical chemical data for the drop tank (Tank 30) had been taken at various times between November 1992 and February 2001 and at various depths. There is a salt layer in Tank 30 at a height of 8". The chemical analysis for a sample taken at 8 " above the tank floor was, therefore, not modeled. Otherwise, the Tank 30 supernate chemistry appeared homogeneous and the delineation of depth populations was not necessary for modeling.

Activity diagrams were generated at $25^{\circ} \mathrm{C}$ (the temperature at which the tank solutions were analyzed), at $40^{\circ} \mathrm{C}$ (the temperature of the feed and drop tanks), and at $140^{\circ} \mathrm{C}$ (the evaporator temperature) with and without a simulated evaporation of $40 \%$. The conclusions of this study are:

- $\quad$ The SRS 3H Evaporator is not precipitating sodium aluminosilicates (NAS) based on the last available accurate data for the SRS 3H Evaporator feed tank (September 2000) and drop tank (December 2000) 


\section{WSRC-TR-2001-00155, Rev. 1}

- The SRS 3H Evaporator feed tank is not in the stability field of sodium aluminosilicate (NAS) formation above the ZOT

- The SRS 3H Evaporator feed tank chemistry is closer to the NAS precipitation boundary than they were in 1992 based on historic data

- Routine analytic samples, if used for modeling the potential for NAS formation, should be taken at the height of the feed pump in order to be representative of the feed entering the evaporator

- Analytic samples should not be taken close to the sludge layer or within the ZOT

- Analytic samples should not be taken within 5-6 hours of tank recycles or tank transfers if subsurface injection of waste under the sludge layer is continued

- Frequent recycles from Tank 30 to Tank 32 beneath the sludge layer are stirring and/or agitating the feed tank contents adding extra silica and iron to the feed tank supernates if not allowed to settle out

- The SRS 3H Evaporator drop tank may have silica sol deposits and/or sludge at or near the level of the transfer jet since higher levels of silica (4X), Fe and Mn are present in the "salt" layer ( 8") in Tank 30 compared to the remaining supernate in Tank 30 \%

- $\quad$ Continued recycle and transfers from the bottom of the drop tank (Tank 30) could cause sodium aluminosilicates to supersaturate

- $\quad$ More accurate Si analyses are needed for modeling

The following recommendations from this study should be implemented as soon as feasible:

- Take routine analytic samples from the height of the feed pump

- Keep the feed pump a minimum of 40" above the sludge layer and a minimum of $\sim 20$ " above the ZOT

- Minimize the depth of the ZOT

- inject recycle and/or transfers above the sludge layer in Tank 32 and not subsurface to minimize agitation and maximize settling of suspended solids and any silica rich sols

- allow the feed tank contents to settle for 5-6 hours after a transfer before feeding to the $3 \mathrm{H}$ Evaporator

$\ddagger \quad$ Tank 30 received one small sludge transfer in September 1986 according to tank farm records. 


\section{WSRC-TR-2001-00155, Rev. 1}

- Move the transfer jet in Tank 30 to a higher position to avoid the region of "salt" which may be mixed with sludge and/or silica sols rather than recycling this material back to the feed tank and possibly the evaporator ** $^{*}$

- Implement a more accurate Si measurement technique in F-Area laboratory immediately

It is desirable that the following recommendation be considered as a longer term strategy:

- Eliminate recycle directly from Tank 30 to the feed tank (Tank 32): use Tanks 39 and/or Tank 35 as settling tanks so that NAS supersaturation and accumulation of silica sol deposits is not of concern

\section{TABLE OF CONTENTS}

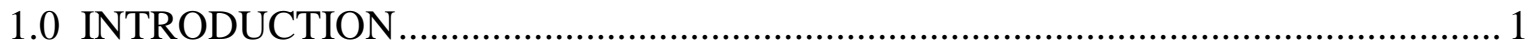

$\ddagger^{*}$ In Spring, 2001 the transfer jet was moved to a height of 150" 
2.0 BACKGROUND ......................................................................................... 2

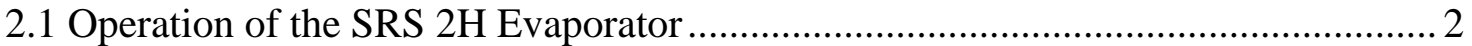

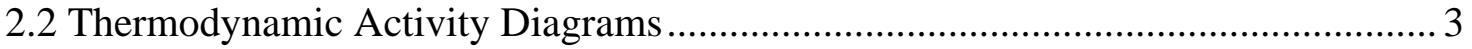

2.3 Zeolite, Sodalite, and Cancrinite Nomenclature and Paragenesis ............................. 5

2.4 The Role of Uranium in the Evaporator Deposits ............................................ 10

3.0 OPERATION OF THE SRS 3H EVAPORATOR ............................................ 11

4.0 ANALYTIC DATA AVAILABLE FOR SRS 3H EVAPORATOR MODELING........ 11

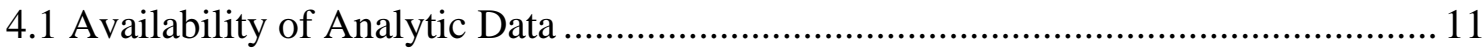

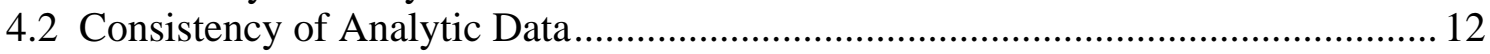

4.3 Quality of Analytic Data ........................................................................... 14

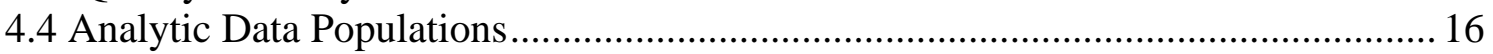

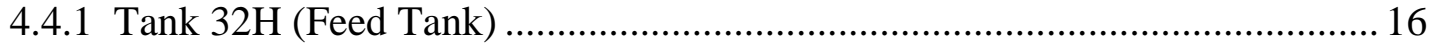

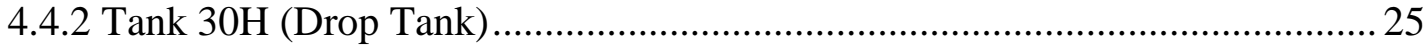

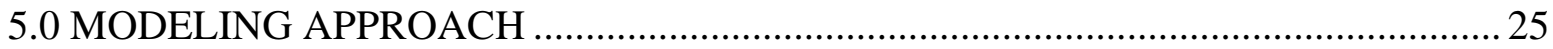

6.0 ACTIVITY DIAGRAMS FOR THE SRS 3H EVAPORATOR ................................ 29

6.1 Activity Diagrams at the Solution Measurement Temperature .............................29

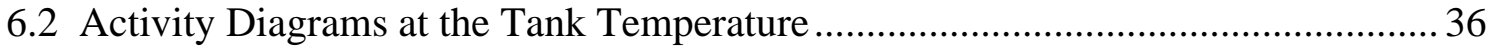

6.3 Activity Diagrams at the Evaporator Temperature .......................................... 38

6.4 Activity Diagrams at the Evaporator Temperature With Simulated

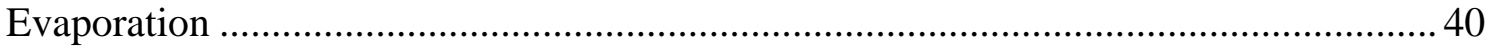

7.0 POTENTIAL FOR DEPOSITION IN THE SRS 3H EVAPORATOR ...................... 41

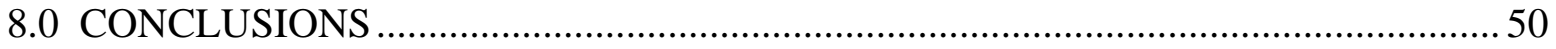

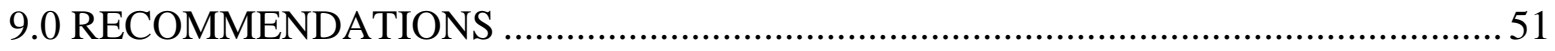

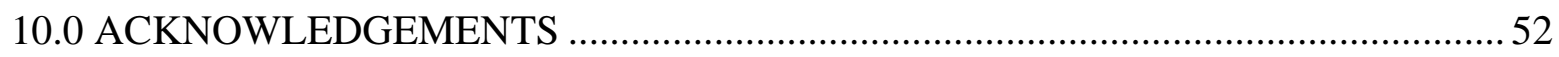

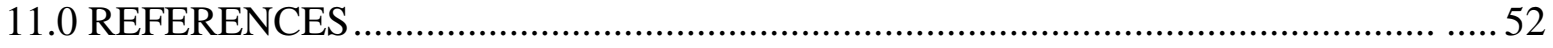




\section{LIST OF FIGURES}

Figure 1. Part of the aluminosilicate framework in the structure of sodalite. 6

Figure 2. Typical aging (densification) sequence of NAS gel $\rightarrow$ Zeolite-A $\rightarrow$ sodalite $\rightarrow$ cancrinite phases.

Figure 3. Schematic of the SRS 3H Evaporator, the feed tank (Tank 32) and the drop tank (Tank 30).

Figure 4. Delineation of depth populations in the SRS 3H Evaporator Feed Tank. .... 17

Figure 5. Pictorial diagram showing the differences between a sol, gel, and precipitate.

Figure 6. Relative Stability Boundaries of NAS gel, “mixed zeolite," Zeolite-A and hydroxysodalite.

Figure 7. Activity diagram for Tank 32 dip samples at $25^{\circ} \mathrm{C}$.

Figure 8. Activity diagrams for Tank 32 dip samples at $25^{\circ} \mathrm{C}$ and $140^{\circ} \mathrm{C}$.

Figure 9 Activity diagram for Tank 32 dip samples at $25^{\circ} \mathrm{C}$ before and after recycle from Tank 30 .

Figure 10. Activity diagram for Tank 32 variable depth samples at $25^{\circ} \mathrm{C}$ before and after recycle from Tank 30 .

Figure 11. Activity diagram for Tank 30 samples (all depths) at $25^{\circ} \mathrm{C}$.

Figure 12. Activity diagram for dip sample (surface sample) compositions in Tank 32 (feed tank) at $40^{\circ} \mathrm{C}$.

Figure 13. Activity diagram for variable depth sample compositions in Tank 32 (feed tank) at $40^{\circ} \mathrm{C}$.

Figure 14. Activity diagram for Tank 30 samples (all depths) at $40^{\circ} \mathrm{C}$ 38

Figure 15. Activity diagram for dip sample (surface sample) compositions in Tank 32 (feed tank) at $140^{\circ} \mathrm{C}$ (no simulated evaporation).

Figure 16. Activity diagram for Tank 32 variable depth samples at $140^{\circ} \mathrm{C}$ before and after recycle from Tank 30 (no simulated evaporation) with $\mathrm{Fe}(\mathrm{OH})_{3}$ formation suppressed. 


\section{WSRC-TR-2001-00155, Rev. 1}

Figure 17. Activity diagram for Tank 30 samples (all depths) at $140^{\circ} \mathrm{C}$ (no simulated evaporation) with the formation of $\mathrm{Fe}(\mathrm{OH})_{3}$ suppressed.

Figure 18. Activity diagram for dip sample (surface sample) compositions in Tank 32 (feed tank) at $140^{\circ} \mathrm{C}$ (with $40 \%$ simulated evaporation) with the formation of $\mathrm{Fe}(\mathrm{OH})_{3}$ suppressed.

Figure 19. Activity diagram for Tank 32 variable depth samples at $140^{\circ} \mathrm{C}$ before and after recycle from Tank 30 (with $40 \%$ simulated evaporation) with the formation of $\mathrm{Fe}(\mathrm{OH})_{3}$ suppressed.

\section{LIST OF TABLES}

Table I. Structurally Related Zeolite-A, Sodalite,and Cancrinite Group Phases ........ 7

Table II. Transfer and Recycle Frequency and Si Analysis for the SRS 3H Evaporator

Table III. Available Tank 32 Analytic Data Including Si for SRS 3H Evaporator Feed Tank

Table IV. Available Tank 30 Analytic Data Including Si for SRS 3H Evaporator Drop Tank

Table V. $\quad$ Tank 32 Modeling Data for SRS 3H Evaporator Feed Tank 23

Table VI. Tank 30 Modeling Data for SRS 3H Evaporator Drop Tank

Table VII. Supersaturation of 3H Evaporator Solutions with Respect to Aluminosilicate Formation 
WSRC-TR-2001-00155, Rev. 1

\section{LIST OF ACRONYMS}

ACT-2: $\quad$ ACTivity Diagram Subroutine in GWB

ANL-W: $\quad$ Argonne National Laboratory-West

DOE: $\quad$ United States Department of Energy

DWPF: Defense Waste Processing Facility

ESP: $\quad$ Extended Sludge Processing

GDL: Gravity Drain Line

GWB: The Geochemist's Workbench Software

LLNL: $\quad$ Lawrence Livermore National Laboratory

NAS: $\quad$ Sodium AluminoSilicate gel

PC: $\quad$ Personal Computer

REACT: Reaction Path Subroutine in GWB

RW-0333P: DOE Level of Quality Assurance

SRS: $\quad$ Savannah River Site

SRTC: $\quad$ Savannah River Technology Center

VDS: $\quad$ Variable Depth Samples

WSRC: Westinghouse Savannah River Company

XRD: $\quad$ X-Ray Diffraction

ZOT: $\quad$ Zone of Turbidity 


\title{
THERMODYNAMIC MODELING OF THE SRS EVAPORATORS: PART II. THE 3H SYSTEM (U)
}

\author{
C. M. Jantzen, J. E. Laurinat and K.G. Brown \\ Savannah River Technology Center \\ Westinghouse Savannah River Company \\ Aiken, South Carolina 29808
}

\subsection{INTRODUCTION}

Accumulations of two solid phases (a nitrated aluminosilicate that is a mixture of nitrated cancrinite, $\mathrm{Na}_{8} \mathrm{Al}_{6} \mathrm{Si}_{6} \mathrm{O}_{24}\left(\mathrm{NO}_{3}\right)_{2} \bullet 4 \mathrm{H}_{2} \mathrm{O}$, and nitrated sodalite, $\mathrm{Na}_{8} \mathrm{Al}_{6} \mathrm{Si}_{6} \mathrm{O}_{24}\left(\mathrm{NO}_{3}\right)_{2}$, simultaneously formed with sodium diuranate, $\mathrm{Na}_{2} \mathrm{U}_{2} \mathrm{O}_{7}$ ) have formed scale deposits in the Savannah River Site (SRS) 2H Evaporator system since late 1996. ${ }^{1,2}$ The aluminosilicate scale deposits caused the evaporator pot to become inoperable in October 1999. Accumulations of the diuranate phase have caused criticality concerns in the SRS $2 \mathrm{H}$ Evaporator. In Part I of this study, ${ }^{3}$ thermodynamically derived activity diagrams, also known as stability diagrams, were used on historic feed tank (Tank 43) and drop tank (Tank 38) chemistry in order to understand the effects of tank chemistry on solids formation in the $2 \mathrm{H}$ Evaporator. In order to ensure that similar deposits are not and will not form in the SRS 3H Evaporator, thermodynamically derived activity diagrams specific to the feeds processed from Tanks 30 and 32 are evaluated in this report.

Activity diagrams are most commonly used in electrochemistry, geochemistry and agronomy to study the effects of various aqueous species on the formation and/or dissolution of solids. Activity diagram representation can, therefore, be used to calculate if an evaporator feed tank composition lies in the formation field of an undesirable solid species. Modeling the deposition of solids in the SRS 3H Evaporator means that activity diagrams must be calculated in the complex Na-N-Si-Al-U-H 2 system at elevated temperatures and at high ionic strengths ( $\sim>8)$. Modeling accuracy is impacted by the following:

- $\quad$ quality of the chemical data available from the feed and drop tanks

- $\quad$ how representative the analytic dip samples from the feed and drop tank are of the feed entering the evaporator

- $\quad$ quality of the solubility data used from the literature

- $\quad$ quality of the approximations that must be made to determine the activity coefficients for high ionic strength solutions.

The quality of the solubility data and the quality of the approximations that are used to model high ionic strength solutions are discussed in Part I of this study. ${ }^{3}$ The quality of the chemical data available for the SRS $2 \mathrm{H}$ and $2 \mathrm{~F}$ Evaporators is also discussed in Part I of this study. ${ }^{3}$ The quality of the chemical data for the SRS $3 \mathrm{H}$ Evaporator is discussed in this study. 
WSRC-TR-2001-00155, Rev. 1

\subsection{BACKGROUND}

\subsection{Operation of the SRS 2H Evaporator}

For $\sim 40$ years, the SRS tank farm evaporators have run with only occasional operational problems, e.g., salt $\left(\mathrm{NaNO}_{3}\right)$ buildup has caused difficulty in draining evaporators but these deposits are water soluble and easily removed by flushing with hot water. Over the last decade several important changes have been made in the handling of wastes entering the SRS evaporators.* Prior to the mid 1990's, high activity waste was stored for $>1$ year before being processed in the evaporators so that the short lived radionuclides could decay before waste was concentrated. This also allowed any solids or colloidal species in the wastes to settle to the bottom of the tank before being processed. When the SRS reactors shut down and wastes were less radioactive, the one year hold strategy was no longer required. In addition, the evaporators used to discharge to alternate drop tanks. When one drop tank was filled it was left to settle, and cool, and a second drop tank was used. Typically recycles to the feed tank were made from the passive drop tank and not from the active drop tank. This allowed any particulates or colloids in a given drop tank to settle before being recycled to the feed tank again for further concentration. The active/passive drop tank practice had to be discontinued in the early 1990's since there was no longer enough salt drop space in the concentrate receipt tanks. In 1997, the $1^{\text {st }}$ inter-area waste transfers were made between the SRS H-area and the SRS F-area waste tanks for the purpose of volume reducing the waste. This allowed co-mingling of wastes of different chemistries. More recently, a decision was made to evaporate canyon processes and back-log waste in the $2 \mathrm{~F}$ evaporator for initial salt separation. This occurs when the hydroxide molarity exceeds $6-8 \mathrm{M}$. Then the desalted liquor will be routed to the $3 \mathrm{H}$ evaporator for final dehydration which would likely drive the hydroxide molarity above $12 \mathrm{M}$

A new 2H Evaporator pot was installed and began receiving waste in January 1996. From mid 1996 until August 1997 the SRS 2H Evaporator was increasingly hard to control. When the evaporator was shut down in August 1997 for cleaning, deposits of the sodium aluminosilicate and sodium uranate phases were found in the gravity drain line (GDL). ${ }^{4}$ The GDL was pressure washed in the direction of the drop tank. The line remained clean and the evaporator showed minimal deposits on the walls or in the lines from August 1997 to June 1998. In June 1998 the GDL needed to be pressure washed a second time and deposits were observed in the evaporator cone, on the vessel walls and on the warming tubes. The GDL was pressure washed in the direction of the evaporator and in the direction of the drop tank to ensure that it was clean. Operation continued, with difficulty, from June 1998 until October 1999, when the evaporator was shut down. At this time, significant accumulations of the same deposits were found on many of the exposed surfaces of the evaporator pot.

\footnotetext{
* Synopsis by Kent Gilbreth, Mark Mahoney, and Thomas Caldwell (May, 2001)

$\ddagger$ HLW System Plan, Rev. 12

2
} 


\section{WSRC-TR-2001-00155, Rev. 1}

Waste from H-Canyon separations processes is typically rich in aluminum species when received in the $2 \mathrm{H}$ Evaporator feed tank (Tank 43) where it undergoes concentration of $60-70 \%$ in the evaporator. However, the newly installed $2 \mathrm{H}$ Evaporator pot received little high alumina waste from High Activity Waste (HAW) processing until April 1998 when H-Canyon resumed operations. In March 1996, Tank 43 received the first radioactive transfers of a silica rich stream from the Defense Waste Processing Facility (DWPF) recycle. The relatively low salt content of the DWPF recycle stream required greater concentration (90\%) than typical $\mathrm{H}$-Canyon wastes to achieve comparable concentrated solution density. Multiple transfers of supernate from the drop tank (Tank 38) were recycled back to the feed tank (Tank 43) for further concentration. At some time after the silica rich DWPF transfers were received from the DWPF and mixed with the aluminum rich transfers from $2 \mathrm{H}$-Canyon separation processes, the sodium aluminosilicate began to form in the $2 \mathrm{H}$ Evaporator.

\subsection{Thermodynamic Activity Diagrams}

Activity diagrams, also known as stability diagrams, have been used for about 60 years in the electrochemical sciences. Marcell Pourbaix developed this graphical representation method in 1938 for studying the corrosion of solids in aqueous solution. The Pourbaix or $\mathrm{E}^{\circ}$ - $\mathrm{pH}$ diagrams are also used to understand the corrosion of metals in concentrated or dilute aqueous solutions, at a variety of temperatures and in oxidizing or reducing atmospheres.

Garrels, a geochemist, studied under Pourbaix and applied the activity diagram calculation approach to complex interactions between minerals and solutions of geological interest. Geochemical applications included examples whereby minerals precipitated from solution as well as examples of how minerals dissolved in various solutions. ${ }^{5,6}$ Activity diagrams are capable of predicting solubilities of solid mineral species in aqueous solutions, equilibria among different solid minerals, and equilibria among different aqueous species. The geologic systems most commonly studied are: (1) the formation or dissolution of minerals in ground water or in sea water at ambient temperatures (for this application they are often called Eh-pH diagrams), ${ }^{7}$ (2) weathering of mineral phases at ambient temperature, ${ }_{7}^{7}(3)$ formation of kaolinite and bauxite deposits from weathering of other mineral species, ${ }^{7}$ and (4) formation of ores from hydrothermal mineralizing solutions at temperatures $\leq 300^{\circ} \mathrm{C}$ and pressures deep within the earth. ${ }^{6}$ Activity diagrams are also used in agronomy to study aerobic and anaerobic soil chemistry: for soil applications they are commonly known as pe-pH diagrams.

Activity diagrams have been used to model the dissolution reactions of zeolites at ambient temperatures: the predicted stability of the zeolite phases has been well correlated with experimental data. ${ }^{8}$ The dissolution of zeolites in the rock at the proposed high level waste (HLW) repository in Yucca Mountain, Nevada has also been modeled and studied in terms of activity diagrams. ${ }^{9}$ It is, therefore, appropriate to use activity diagram representation to model the nitrated cancrinite/sodalite found to deposit in the SRS 2H Evaporator, since the cancrinite/sodalite forms from a precursor zeolite phase which in turn forms from a sodium aluminosilicate (NAS) gel (see Section 2.3). 


\section{WSRC-TR-2001-00155, Rev. 1}

Activity diagrams can be used to thermodynamically predict both mineral phase formation and dissolution on geologic time scales. However, the formation of the NAS gel precursor to nitrated cancrinite/sodalite and sodium diuranate is kinetically rapid, occurring in a few minutes or hours (see Sections 2.3 and 2.4). This allows the thermodynamically based activity diagrams to be used as a predictive tool for the evaporator's short residence times.

In the past, activity diagrams have been calculated manually which is a tedious process. Often mainframe computers were necessary to solve the simultaneous equilibrium equations. Recently, several software applications have become available to allow the activity diagram calculations and plots to be generated on a personal computer (PC). The one used in this study is called The Geochemist's Workbench (GWB) because it is particularly well suited to the thermodynamic calculations related to the SRS evaporators. The GWB was recently used to analyze the cancrinite/sodalite and sodium diuranate solubilities and stability the SRS $2 \mathrm{H}$ Evaporator. ${ }^{3}$ The GWB software has the following attributes:

- ability to estimate activity coefficients for high ionic strength solutions such as those in the evaporator

- ability to improve the basis upon which the activity coefficients are estimated

- usage of Lawrence Livermore National Laboratory (LLNL) extensive database for minerals and aqueous species used to model the performance of waste forms in the High Level Waste (HLW) Repository

- includes sodium diuranate and aqueous uranate species as well as most aqueous aluminates and silicates

- ability to calculate the relative stability of multiple solid phases simultaneously

- ability to graphically represent the relative stability of multiple phases in terms of three parameters simultaneouly, e.g. $\mathrm{Si}, \mathrm{Al}$, and $\mathrm{pH}$ of a solution

- ability to perform polythermal reaction paths, e.g. reaction path can vary temperature linearly from an initial to a final value so that chemical analyses that are measured at $25^{\circ} \mathrm{C}$ can be evaluated at the elevated tank temperatures $\left(40-60^{\circ} \mathrm{C}\right)$ and elevated evaporator temperatures of $140^{\circ} \mathrm{C}$

- ability to simulate evaporation by removing a percentage of the water from the calculation, e.g. base the calculation on $0.6 \mathrm{~kg}$ of water rather than on the default of $1 \mathrm{~kg}$ of water for a simulated $40 \%$ evaporation

- ability to calculate a supersaturation index for a given solid phase expressed as a ratio of the reaction quotient $(\mathrm{Q})$ over the solubility product (K), e.g. Q/K

- ability to calculate the amount of the solid phase (in $\mathrm{g}_{\text {(solid })} / \mathrm{kg}_{\text {(soln) }}$ ) that will form at the given supersaturation if precipitation to equilibrium proceeds.

Two subroutines in GWB were used to model the precipitation of solids in the complex $\mathrm{Na}-\mathrm{N}-\mathrm{Si}-\mathrm{Al}-\mathrm{U}-\mathrm{H}_{2} \mathrm{O}$ system pertinent to the SRS 2H Evaporator; e.g. REACT and ACT2. 


\section{WSRC-TR-2001-00155, Rev. 1}

The REACT subroutine models equilibrium states and processes of solids in equilibrium with aqueous fluids. The program calculates the following:

- equilibrium distribution of aqueous species in a fluid

- the fluid's saturation state with respect to mineral phases

- the fugacities of the gases dissolved in the fluid

During the modeling of deposition in the $2 \mathrm{H}$ Evaporator using GWB several mineral phases that were known to kinetically form on geologic time scales, but not on the time scales pertaining to the $2 \mathrm{H}$ Evaporator, were suppressed. The ACT2 program was used to calculate and plot activity-activity diagrams for representation of the solids precipitation. The manner in which GWB calculates equilibrium and estimates activity coefficients in high ionic strength solutions such as those in the SRS evaporators is discussed in Part I of this report. ${ }^{3}$ The amount of solids predicted to form in grams per kilogram of solution was developed into two potential process control algorithms for the operation of the SRS 2H Evaporator.

The GWB calculations in the complex Na-N-Si-Al-U-H $\mathrm{O}_{2} \mathrm{O}$ system were validated by modeling two additional data sets not related to solids deposition in the SRS evaporators. The first of these was the analysis of the M-Area wastes (supernate plus sludge) from 1987 when the M-Area tanks were well agitated. ${ }^{10}$ This waste was high in alumina, silica, and sodium nitrate. The tanks were at ambient temperature. The REACT code predicted that the solutions were supersaturated with respect to Zeolite-A, hydroxysodalite, nitrated sodalite, $\mathrm{Na}_{2} \mathrm{U}_{2} \mathrm{O}_{7}$ (sodium diuranate), and $\mathrm{Al}(\mathrm{OH})_{3}$ (gibbsite). The phases identified by $\mathrm{X}$-ray diffraction to have formed in the sludge were Zeolite- $\mathrm{A}, \mathrm{Na}_{2} \mathrm{U}_{2} \mathrm{O}_{7}$, and $\mathrm{Al}(\mathrm{OH})_{3}{ }^{{ }^{10}}$ The second set of confirmatory data was from a study of caustic additions to a highly acidic concentrated uranyl nitrate solution. ${ }^{11}$ The REACT code indicated that a precipitate of schoepite should be in equilibrium with uranyl nitrate in solution. Pierce's solution remained acidic after he started the neutralization, but a precipitate formed that was analyzed by x-ray diffraction to be becquerelite (PDF pattern \#29-0389) a structural isomer of schoepite $\left(\mathrm{UO}_{2} \cdot 2 \mathrm{H}_{2} \mathrm{O}\right){ }^{12}$ Both of these independent studies validated that $\mathrm{GWB}$ is calculating the activity diagrams and the reactions in this complex system correctly.

\subsection{Zeolite, Sodalite, and Cancrinite Nomenclature and Paragenesis}

The type of sodalite normally found in nature has the formula $\mathrm{Na}_{8}\left[\mathrm{Al}_{6} \mathrm{Si}_{6} \mathrm{O}_{24}\right]\left(\mathrm{Cl}_{2}\right)$. The square brackets in the formula are used to delineate the alumina:silica ratio of the aluminosilicate cage structure shown in Figure 1. The cavities in the framework are occupied by the sodium and chlorine ions. ${ }^{13}$ The formula can also be written as $\mathrm{Na}_{6}\left[\mathrm{Al}_{6} \mathrm{Si}_{6} \mathrm{O}_{24}\right] \bullet(2 \mathrm{NaCl}) .{ }^{13}$ When the $2 \mathrm{NaCl}$ are replaced by $\mathrm{Na}_{2} \mathrm{SO}_{4}, \mathrm{Na}_{2} \mathrm{CO}_{3}, 2 \mathrm{NaNO}_{3}$, and/or $2 \mathrm{NaOH}$, the mineral and/or chemical names are as given in Table I. 


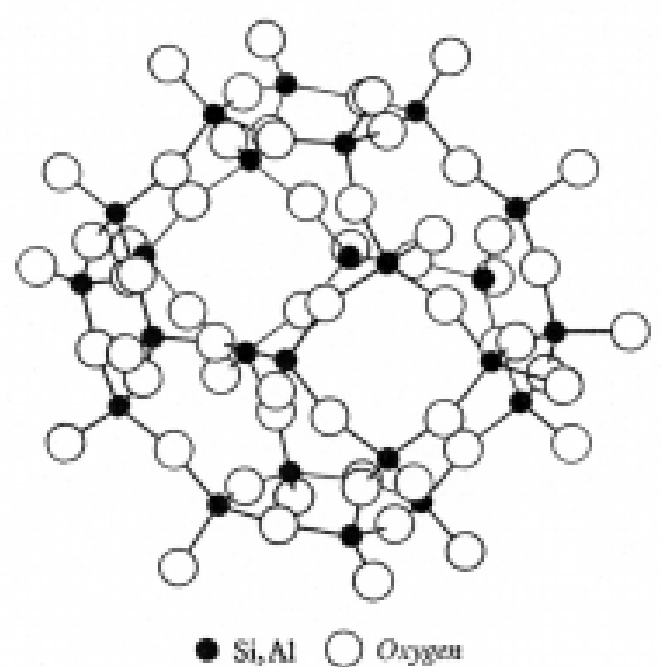

Figure 1. Part of the aluminosilicate framework in the structure of sodalite. ${ }^{13}$

Linde Zeolite-A, $\mathrm{Na}_{12}\left[\mathrm{Al}_{12} \mathrm{Si}_{12} \mathrm{O}_{48}\right] \cdot 27 \mathrm{H}_{2} \mathrm{O}$, is a phase related structurally to basic sodalite and basic nosean ${ }^{20}$ because the alumina:silica ratio of the aluminosilicate cage structure is the same as that found in the sodalites (Figure 1). Zeolite-A is a double unit cell of sodalite without the $\mathrm{NaCl}, \mathrm{Na}_{2} \mathrm{SO}_{4}, \mathrm{NaOH}$, or $\mathrm{Na}_{2} \mathrm{CO}_{3}$ groups (Table I).

Recent work at Argonne National Laboratory-West (ANL-W) on sodalite based ${ }^{\dagger}$ waste forms containing $\mathrm{NaCl}$ found that Zeolite-A formed as a precursor to the formation of sodalite, $\mathrm{Na}_{8}\left[\mathrm{Al}_{6} \mathrm{Si}_{6} \mathrm{O}_{24}\right]\left(\mathrm{Cl}_{2}\right){ }^{14}$ The Zeolite-A transformed to $\mathrm{Na}_{8}\left[\mathrm{Al}_{6} \mathrm{Si}_{6} \mathrm{O}_{24}\right]\left(\mathrm{Cl}_{2}\right)$ at elevated temperature and pressure. Wilmarth ${ }^{15}$ has determined that a mixture of the nitrated sodalite and nitrated cancrinite formed in the $2 \mathrm{H}$ evaporator also forms from a Zeolite-A precursor while Frederick determined that mixtures of nitrited sodalite and cancrinite found to deposit in spent pulping liquor evaporators also formed from a Zeolite-A precursor. ${ }^{16}$ The studies by Gasteiger, Frederick, et al. ${ }^{17}$ precipitated the zeolite and mixed sodalite phases in the $[\mathrm{Al}] /[\mathrm{Si}]$ range between 0.076 and 3 . These aqueous alkaline solutions had ionic strengths between 1.0 and $4.0 \mathrm{~mol} / \mathrm{kg}$ at $95^{\circ} \mathrm{C}$.

The formation of Zeolite-A is well studied and very rapid kinetically. Formation from a sodium aluminate gel $\left(87 \mathrm{wt} \% \mathrm{NaAlO}_{2}\right.$ and $13 \mathrm{wt} \% \mathrm{NaOH}$ commercially available as Alfloc) and a $1 \mathrm{M}$ colloidal silica sol (particles of $250 \AA$ )formed well crystallized ZeoliteA (also called Zeolite Q by Barrer, et. al. ${ }^{20}$ ) at temperatures between $85-110^{\circ} \mathrm{C}$ at $\mathrm{pH}$ values $\geq 10$ in 2 or 3 hours (longer residence times were needed if the silica content of the gel increased and crystallization was more rapid in the presence of excess $\mathrm{NaOH}){ }^{20,18}$

\footnotetext{
$\dagger$ waste form is $69 \mathrm{wt} \%$ sodalite, $22 \mathrm{wt} \%$ glass, $2.4 \mathrm{wt} \% \mathrm{NaCl}, 6.7 \mathrm{wt} \%$ nepheline, and $1 \mathrm{wt} \%$ actinides 6
} 
WSRC-TR-2001-00155, Rev. 1

Table I. Structurally Related Zeolite-A, Sodalite,and Cancrinite Group Phases

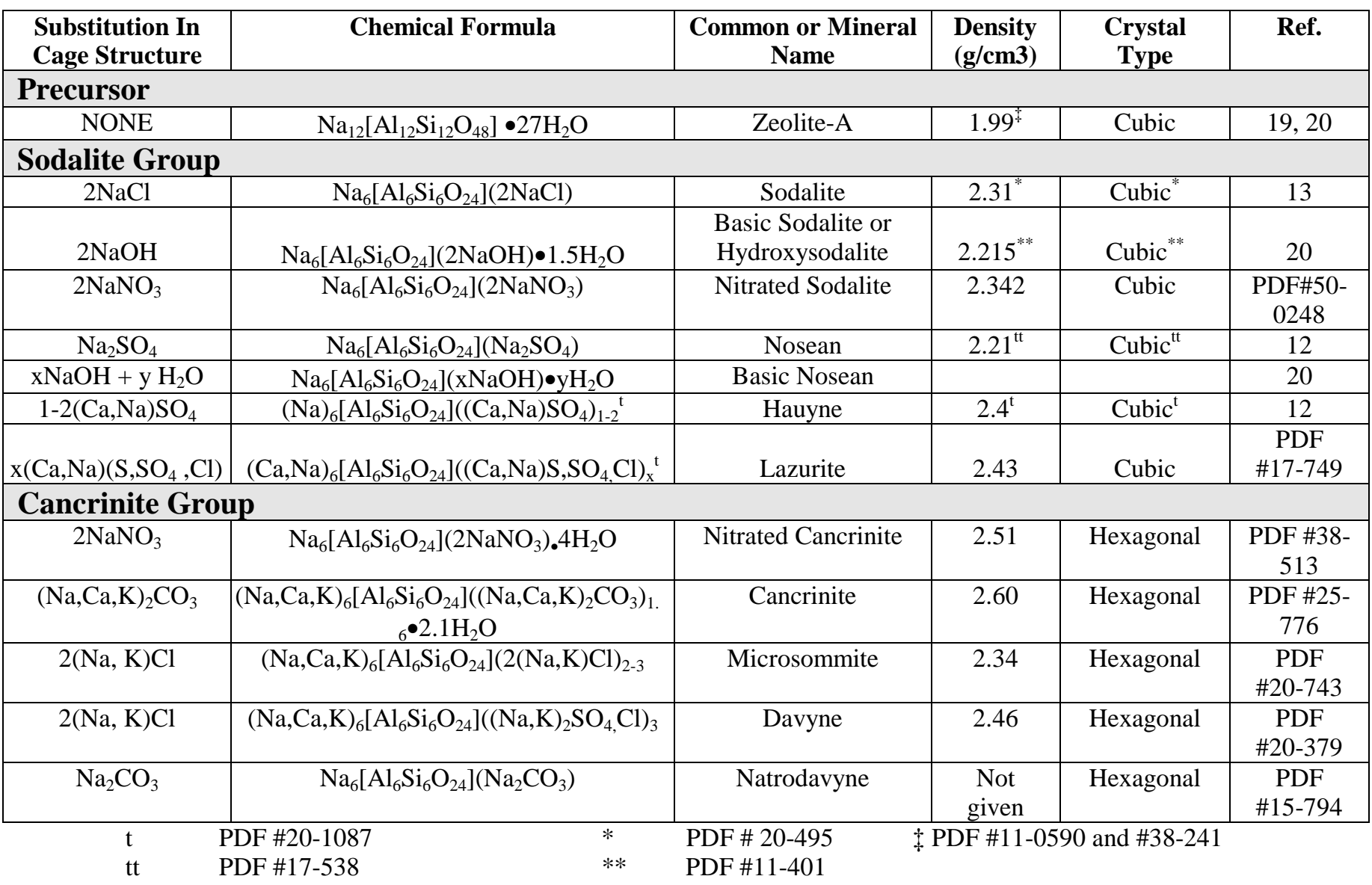

Zeolite-A $\left(\mathrm{Na}_{12} \mathrm{Al}_{12} \mathrm{Si}_{12} \mathrm{O}_{48} \bullet 27 \mathrm{H}_{2} \mathrm{O}\right)$ had also been found to form in the SRS M-Area waste tanks at ambient temperature. ${ }^{10}$ Zeolite was found to form preferentially in tanks with high $\mathrm{pH}(12-12.8)$ when sufficient $\mathrm{Al}(\mathrm{OH})_{3}$ was present. Since no zeolite had been used in any M-Area processes, experiments were performed ${ }^{10}$ to determine how ZeoliteA got into the tanks. These experiments demonstrated that the zeolite could form rapidly from the interaction of high surface area filter aids in the tank (perflo and diatomaceous earth $\ddagger$. Sodalite formed when the filter aids were placed in $6 \mathrm{M} \mathrm{NaOH}$ at room temperature for 29 hours at a $\mathrm{pH}$ of 13.73 .

As indicated in the preceding discussion, the Zeolite-A structure can form (1) from a hydrogel process where the reactants are reactive oxides, soluble silicates, and soluble aluminates in a caustic solution; (2) from conversion of clay minerals (specifically kaolin and meta-kaolin) in the presence of soluble silicates and caustic; or (3) by reaction of

$\ddagger$ perflo $=\mathrm{K}_{0.08} \mathrm{Na}_{0.08} \mathrm{Al}_{0.16} \mathrm{Si}_{0.81} \mathrm{O}_{1.94}$ and diatomaceous earth $=\mathrm{K}_{0.06} \mathrm{Na}_{0.06} \mathrm{Al}_{0.18} \mathrm{Si}_{0.61} \mathrm{O}_{1.55} \bullet 0.22 \mathrm{H}_{2} \mathrm{O}$. 


\section{WSRC-TR-2001-00155, Rev. 1}

silica sols, natural $\mathrm{SiO}_{2}$, amorphous minerals, and volcanic glass in the presence of caustic. ${ }^{3}$ The hydrogel reactions are of the type:

$$
\begin{aligned}
& \mathrm{NaOH}(\mathrm{aq})+\mathrm{NaAl}(\mathrm{OH})_{4}(\mathrm{aq})+\mathrm{Na}_{2} \mathrm{SiO}_{3}(\mathrm{aq}) \stackrel{25^{\circ} \mathrm{C}}{\longrightarrow} \\
& {\left[\mathrm{Na}_{\mathrm{a}}\left(\mathrm{AlO}_{2}\right)_{\mathrm{b}}\left(\mathrm{SiO}_{2}\right)_{\mathrm{c}} \bullet \mathrm{NaOH} \bullet \mathrm{H}_{2} \mathrm{O}\right]_{\mathrm{gel}} \stackrel{25-175^{\circ} \mathrm{C}}{\text { hydrothernal }} \longrightarrow \mathrm{Na}_{\mathrm{x}}\left[\left(\mathrm{AlO}_{2}\right)_{\mathrm{x}}\left(\mathrm{SiO}_{2}\right)_{\mathrm{y}}\right] \bullet \mathrm{mH}_{2} \mathrm{O}}
\end{aligned}
$$

Zeolites are synthesized industrially using the hydrogel process shown in Equation 1. Upon mixing sodium silicate and sodium aluminate at high $\mathrm{pH}$ an amorphous sodium aluminosilicate gel phase forms which will be abbreviated as NAS gel. Transformation of the gel to the zeolite can take hours or days depending upon the synthesis conditions. Industrial synthesis of Zeolite-A involves solutions use of $4.0 \mathrm{M} \mathrm{NaOH}$ concentrations to keep the crystallization times short and allow effective recycling of the excess $\mathrm{NaOH} .{ }^{21}$ The dissolution of Zeolite-A has been studied by numerous investigators including Gasteiger, et. al. ${ }^{17}$ but these investigations have been at insufficiently high $\mathrm{NaOH}$ concentrations to be relevant to industrial zeolite synthesis. ${ }^{22}$ Recently, Ejaz et. al. ${ }^{22}$ studied the solubility of Zeolite-A and its amorphous precursor (NAS gel) in solutions between $3.0-4.4 \mathrm{M} \mathrm{NaOH}$ at temperatures of $30-80^{\circ} \mathrm{C}$. The composition of the precursor gel at $\mathrm{NaOH}$ concentrations of $3-4.5 \mathrm{M}$ was determined experimentally to be $0.93 \mathrm{Na}_{2} \mathrm{O}: 1 \mathrm{Al}_{2} \mathrm{O}_{3}: 2.32 \mathrm{SiO}_{2}: 5.15 \mathrm{H}_{2} \mathrm{O}$.

Gels are amorphous as they are colloids in which the disperse phase has combined with the continuous phase to produce a semisolid material such as a jelly. ${ }^{23}$ As a gel dewaters or ages it will form a denser gel and/or a crystalline solid phase. This is independent of the route of formation of the gel. Whether the NAS gel forms from solution via a hydrogel process or whether it forms from a sol (solid particles in liquid) ${ }^{24}$ via a sol-gel process, the aging sequence of the NAS gel to denser sodalite and still denser cancrinite type species will typically follow an aging path such as that shown in Figure 2 according to Barnes, Mensah and Gerson ${ }^{25}$ and Gerson and Zheng. ${ }^{26}$ Note that the densification of the phases follows the densities given in Table I and agrees with the following literature:

- Bayer $^{20}$ and $\mathrm{Ejaz}^{22}$ found that the NAS hydrogels would transform to Zeolite-A

- Barrer $^{20}$ found that the NAS hydrogels would transform to Zeolite-A at $\mathrm{pH}$ values $>10$ in $2-3$ hours at $110^{\circ} \mathrm{C}$ (the approximate temperature of the $2 \mathrm{H}$ Evaporator)

- Buhl and Lons ${ }^{27}$ showed that nitrated sodalite and nitrated cancrinite could best be made by starting with a Zeolite-A precursor in concentrated $\mathrm{NaOH}$ at various temperatures

- Wilmarth ${ }^{28}$ showed that the Zeolite-A forms as a precursor but the nitrated cancrinite forms on the order of $3-5$ hours at $110^{\circ} \mathrm{C}$ in simulated $2 \mathrm{H}$ Evaporator solutions

- Gasteiger et al. ${ }^{17}$ found that basic sodalite $\mathrm{Na}_{8}\left[\mathrm{Al}_{6} \mathrm{Si}_{6} \mathrm{O}_{24}\right](\mathrm{OH})_{2} \bullet\left(1.5 \mathrm{H}_{2} \mathrm{O}\right)$ and sodalite $\left(\mathrm{Na}_{8}\left[\mathrm{Al}_{6} \mathrm{Si}_{6} \mathrm{O}_{24}\right](\mathrm{Cl})_{2}\right)$ formation was $>99 \%$ complete in 24 hours at $95^{\circ} \mathrm{C}$ and that the sodalites formed via a Zeolite-A precursor 
- $\quad$ Subotic, et. al. ${ }^{29}$ demonstrated that aluminosilicate gels that have a $\mathrm{Si} / \mathrm{Al}=1$ form Zeolite-A at lower $\mathrm{NaOH}$ concentrations in solution at $85^{\circ} \mathrm{C}$ which then transforms into hydroxysodalite; at higher $\mathrm{NaOH}$ concentrations the gel can transform into hydroxysodalite without the Zeolite-A precursor formation

- Bosnar and Subotic ${ }^{30}$ demonstrated that Zeolite-A forms from an amorphous aluminosilicate precursor $\left(1.03 \mathrm{Na}_{2} \mathrm{O} \bullet \mathrm{Al}_{2} \mathrm{O}_{3} \cdot 2.38 \mathrm{SiO}_{2} \cdot 1.66 \mathrm{H}_{2} \mathrm{O}\right)$ and the Zeolite-A growth is governed by the Davies-Jones model of growth and dissolution (growth of Zeolite-A from solution coupled with dissolution of the amorphous phase); growth rate decreases with increasing alkalinity

Note that the amorphous aluminosilicate gel precursor of Ejaz ${ }^{22}$

$\left(0.93 \mathrm{Na}_{2} \mathrm{O}: 1 \mathrm{Al}_{2} \mathrm{O}_{3}: 2.32 \mathrm{SiO}_{2}: 5.15 \mathrm{H}_{2} \mathrm{O}\right)$ is very similar to that reported by Bosnar and Subotic $^{30}\left(1.03 \mathrm{Na}_{2} \mathrm{O}: \mathrm{Al}_{2} \mathrm{O}_{3}: 2.38 \mathrm{SiO}_{2}: 1.66 \mathrm{H}_{2} \mathrm{O}\right)$ but not identical.

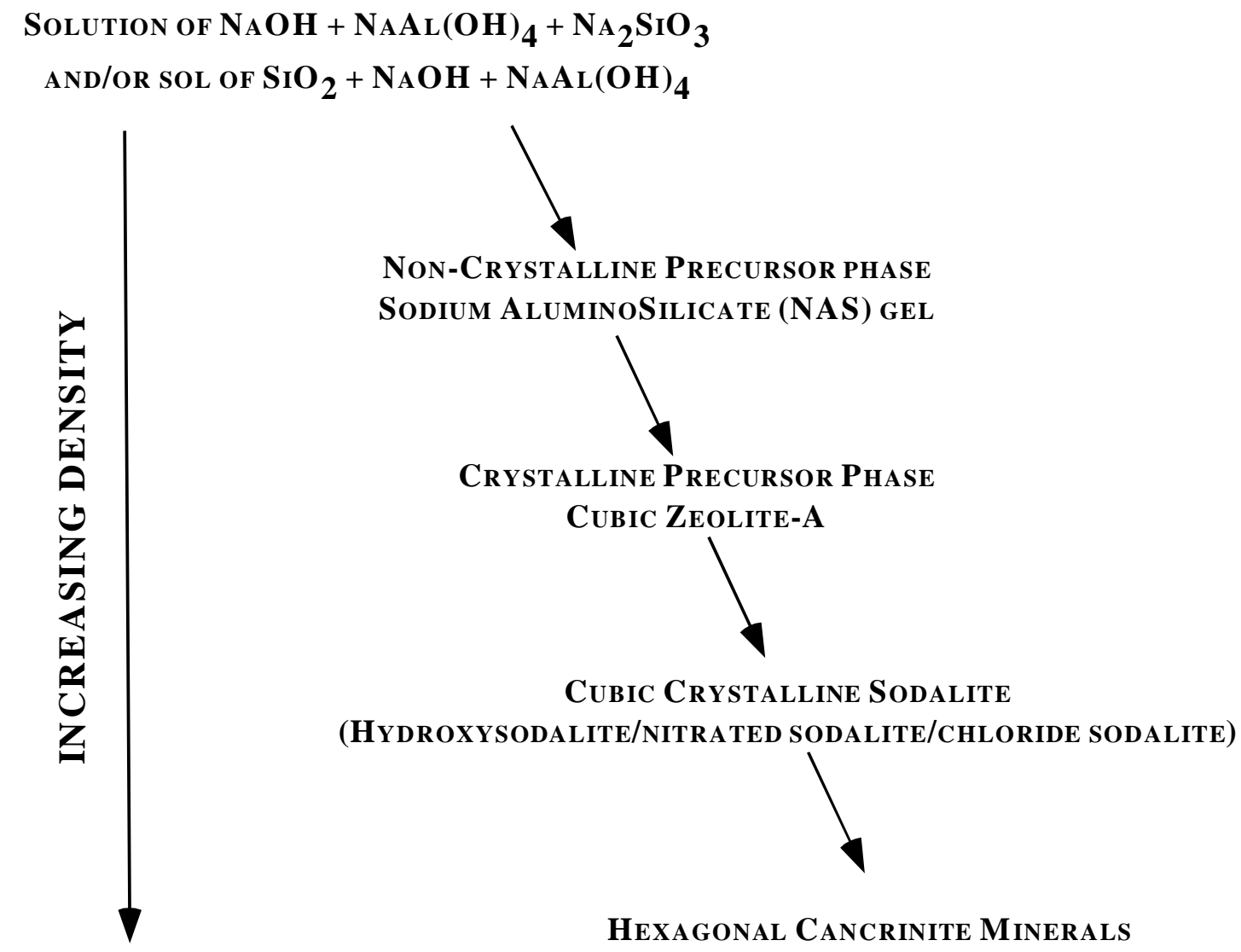

Figure 2. Typical aging (densification) sequence of NAS gel $\rightarrow$ Zeolite-A $\rightarrow$ sodalite $\rightarrow$ cancrinite phases depending on the relative concentration of $\mathrm{OH}^{-}, \mathrm{Cl}^{-}, \mathrm{NO}_{3}{ }^{-}$, and/or $\mathrm{CO}_{3}{ }^{2}$ in the solution in contact with the NAS gel (after Gerson, et.al. $)^{25,26}$ 


\section{WSRC-TR-2001-00155, Rev. 1}

\subsection{The Role of Uranium in the Evaporator Deposits}

It is highly unlikely that the uranium contained in the $2 \mathrm{H}$ Evaporator deposits is incorporated into the cage structure of the Zeolite-A and/or cancrinite/sodalite phases. The ion exchange capacity of $\mathrm{Na}^{+}$in the Zeolite-A structure for large monovalent ions is minimal, e.g., $\mathrm{Cs}^{+}$and $\mathrm{Rb}^{+}$exchanged at $90^{\circ} \mathrm{C} \sim 31 \%$ and $36 \%$, respectively. ${ }^{31}$ Ion exchange with multivalent cations is limited with ions such as $\mathrm{Ba}^{2+}, \mathrm{Fe}^{2+}$, and $\mathrm{Fe}^{3+}$ exchanging but destroying the zeolite structure while large trivalent cations such as $\mathrm{Ce}^{3+}$ do not exchange at all. ${ }^{31}$ This implies that large tetra- or hexa-valent cations which are most likely tied up in uranium complexes cannot ion exchange for $\mathrm{Na}^{+}$in the Zeolite-A and/or the cancrinite/sodalite structures. This is in agreement with the following:

- the absence of any uranium containing sodalite or cancrinite structures in nature $^{13}$

- the absence of uranium in the sodalite phase of the ANL-W sodalite waste form ${ }^{14}$

- the presence of a second uranium-containing phase in the $\mathrm{x}$-ray spectra of the $2 \mathrm{H}$ Evaporator deposits. ${ }^{1,2,4}$

The uranium containing phase observed in the $2 \mathrm{H}$ Evaporator is sodium diuranate $\left(\mathrm{Na}_{2} \mathrm{U}_{2} \mathrm{O}_{7}\right)$. Sodium diuranate can form readily from mixtures of $0.1 \mathrm{~N}$ uranyl nitrate and $\mathrm{NaOH}$ at room temperature in time frames of $<24$ hours. The ratio of the Na: $\mathrm{U}$ in the polyuranate phase that forms is a function of $\mathrm{pH}$ of the solution and the length of time that the $\mathrm{Na}$ has to diffuse into the crystal structure. ${ }^{32}$ Specifically, when $\mathrm{NaOH}$ was added to dilute solutions of uranyl nitrate, the first species to form was a polymerized ion of the form $\left[\mathrm{UO}_{2}\left(\mathrm{UO}_{3} \mathrm{H}_{2} \mathrm{O}\right)_{\mathrm{n}}\right]^{++}$, followed by precipitation of a nitrated uranate phase with a polymer chain of $\left[\left(\mathrm{UO}_{3} \mathrm{H}_{2} \mathrm{O}\right)_{5} \mathrm{~N}_{2} \mathrm{O}_{5}\right]$ at $\mathrm{pH}$ of $4 .{ }^{32}$ As the solution $\mathrm{pH}$ increases with increasing $\mathrm{NaOH}, \mathrm{Na}_{2} \mathrm{O}$ replaces the $\mathrm{N}_{2} \mathrm{O}_{5}$ in the polymer chain forming $\left[\left(\mathrm{UO}_{3} \mathrm{H}_{2} \mathrm{O}\right)_{\mathrm{n}} \mathrm{Na}_{2} \mathrm{O}\right]$ where $\mathrm{n}$ changes from 16 at low $\mathrm{pH}$ values to 5 at higher $\mathrm{pH}$ values. Longer contact with the $\mathrm{NaOH}$ rich solution at high $\mathrm{pH}$ causes $\mathrm{n}$ to become $\leq 3$ causing a change in the crystal structure. At $n=2$ the final stable $\mathrm{Na}_{2} \mathrm{U}_{2} \mathrm{O}_{7} \cdot 2 \mathrm{H}_{2} \mathrm{O}$ composition is formed. Similar results were observed when reactive $\mathrm{UO}_{3}$ was treated with $\mathrm{NaOH}$ at $50^{\circ} \mathrm{C}$ and $75^{\circ} \mathrm{C}^{33}$ It should be noted that in both of these studies ${ }^{32,33}$ the $\mathrm{Na}_{2} \mathrm{U}_{2} \mathrm{O}_{7}$ precipitates were very small and suspended in the $\mathrm{NaOH}$ solutions, i.e., the precipitates had to be centrifuged in order to be examined. Finely dispersed sodium diuranate phases were found to form readily at $25^{\circ} \mathrm{C}$ in about $10-60$ minutes, ${ }^{32}$ reaching equilibrium in about 5 days. 34

Hobbs and Karraker ${ }^{35}$ studied the precipitation of $\mathrm{Na}_{2} \mathrm{U}_{2} \mathrm{O}_{7}$ in simulated evaporator solutions under simulated evaporator conditions. The precipitates that formed had particle size ranges between $3.3 \mu \mathrm{m}$ and $60 \mu \mathrm{m}$ for unsaturated solutions and $2.3 \mu \mathrm{m}$ to $13 \mu \mathrm{m}$ for supersaturated solutions. The studies indicated that $\mathrm{Na}_{2} \mathrm{U}_{2} \mathrm{O}_{7}$ would precipitate under evaporator conditions and might accumulate depending on particle size, mixing, and equipment geometry. The accumulation of $\mathrm{Na}_{2} \mathrm{U}_{2} \mathrm{O}_{7}$ with the nitrated zeolite in the 
$2 \mathrm{H}$ Evaporator is likely caused by co-precipitation as discussed in Part $\mathrm{I}^{3}$ Precipitation of uranium and not other salts (e.g. sodium sulfate, sodium carbonate, etc) would be expected as the solubility of uranium is much lower than that of the other salt components.

\subsection{OPERATION OF THE SRS 3H EVAPORATOR}

The current SRS 3H Evaporator pot began operation in May 2000 (Table II). The 3H Evaporator feed tank is Tank 32 and the drop tank is Tank 30. The initial feed for the $3 \mathrm{H}$ Evaporator was H-Canyon waste that had been stored in Tanks 30, 32, and 35 for many years. In the future the $3 \mathrm{H}$ Evaporator will receive de-salted waste from the $2 \mathrm{~F}$ Evaporator system for further concentration. Tank 32 can potentially be feed from Tanks 35 and 39 but feed from these tanks has not yet been sent forward to Tank 32 since initial operations.

Tank 32 has received multiple recycles of supernate from the drop tank (Tank 30) as indicated in Table II. The recycle is approximately on a 4-6 week frequency though it can be more frequent depending on the level of the wastes in the feed and drop tanks. Tank 32 has about 48" of sludge at the bottom (Figure 3 ). The transfer pump to the evaporator is located at a height of 89 " from the bottom of the tank. The level of the supernate varies depending on the volume of a given transfer into the tank.

Tank 30, the drop tank has no significant sludge accumulation at the bottom other than some entrained sludge solids. It had a transfer jet that was located 4" above the bottom of the tank (Figure 3) during the time period discussed in this study. ${ }^{*}$ The salt layer is at $\sim$ " above the bottom of the tank. Tank 30 received Extended Sludge Processing (ESP) Washwater from Tank 40 in December 2000.

The $3 \mathrm{H}$ Evaporator has been operating at $135-140^{\circ} \mathrm{C}$ since May 2000 * Tanks 32 and 30 have been at a nominal temperature of $\sim 40^{\circ} \mathrm{C}$ until a few months ago when cooling coil difficulties in Tank 30 caused the temperature in Tank 32 to be elevated to the $60-65^{\circ} \mathrm{C}$ range. ${ }^{\ddagger}$ The temperature in Tank 30 has recently been somewhat hotter.

\subsection{ANALYTIC DATA AVAILABLE FOR SRS 3H EVAPORATOR MODELING}

\subsection{Availability of Analytic Data}

A compilation of molar chemical analyses for Tanks 30 and 32 appears in Table III and Table IV. There were sparse and incomplete data in the tank farm historic records. Specifically there were no Si analyses available for the feed tank (Tank 32) compositions prior to February 2000 and no Si analyses available for the drop tank (Tank 30) compositions prior to February 2000. Data for several cations were missing from the

\footnotetext{
* In spring 2001 ther fixed transfer jet was replaced with a telescoping transfer jet currently positioned at $\sim 150$ " from the tank floor

$\ddagger$ Morning reports
} 


\section{WSRC-TR-2001-00155, Rev. 1}

tank farm historic records, e.g. Si, Fe, Al, Na, and total U. The cation analyses were added into Table III and Table IV using data from three reports by Wilmarth and others. ${ }^{36,}$ ${ }^{37,38}$ Conversely, Wilmarth did not analyze for the cation $\mathrm{K}^{+}$nor several anions, ${ }^{\dagger}$ e.g. $\mathrm{Cl}$, $\mathrm{CO}_{3}^{2-}, \mathrm{F}^{-}, \mathrm{NO}_{2}^{-}, \mathrm{NO}_{3}^{-}, \mathrm{OH}^{-}, \mathrm{PO}_{4}^{3-}, \mathrm{SO}_{4}^{2-}$. The anion and $\mathrm{K}$ analyses shown in yellow in Table III and Table IV were averaged from the data provided in the tank farm records. Separate averages were computed for Tank 30 and Tank 32 data.

The feed tank (Tank 32) was sampled in February 2000 before the operation of the new $3 \mathrm{H}$ Evaporator pot began (Table III). This data represents the initial feed to the new $3 \mathrm{H}$ Evaporator pot since no transfers were made to Tank 32 after February 15, 2000 (see Table II). Wilmarth extensively characterized two dip samples and two variable depth samples (VDS) taken from Tank 32 in February $2000 .^{36}$ Wilmath also analyzed Tank 32 surface dip and VDS samples in August 2000 just before a recycle was made from Tank 30 to $32 .{ }^{37}$ He then immediately analyzed samples taken in Tank 32 during the Tank 30 transfer in September 2000. ${ }^{37}$

The chemistry of the drop tank, Tank 30, was also analyzed in February 2000 (Table II) by Wilmarth, et. al. ${ }^{37}$ Tank 30 was also analyzed in August 2000 just before the recycle to the Tank 32 feed tank. In addition a transfer of ESP wash water was made from Tank 40 to Tank 30 in December 2000. Wilmarth analyzed the contents of Tank 30 just after the transfer from Tank 40 (see Table II). ${ }^{38}$

\subsection{Consistency of Analytic Data}

In order to use the chemical analyses compiled in Table III and Table IV for modeling, the data had to be made internally consistent, e.g., anion and cation charges were balanced. In balancing charges, it was assumed that measured $\mathrm{Na}^{+}$molarities were more accurate than the anion molarities. If the sum of the anion charges differed significantly from the sum of the cation charges, molarities of the three principal anions, $\mathrm{OH}^{-}, \mathrm{NO}_{3}^{-}$, and $\mathrm{NO}_{2}{ }^{-}$, were adjusted so that these sums became equal. The measured molarities for all three principal anions were multiplied by the same factor to achieve charge neutrality. Data for which anion charges were adjusted are shaded green in Table III and Table IV. The charge balance calculations assumed that each ionic species was present in its most prevalent valence state; most importantly, $\mathrm{Al}$ was modeled as $\mathrm{Al}(\mathrm{OH})_{4}{ }^{-}$.

In order to account for the effect of temperature on solution densities so that the data in Table III and Table IV could be evaluated at different temperatures, molar concentrations were converted to molalities (Table V and Table VI). The molalities are based on calculated solution densities (Equation 2a). ${ }^{7}$ The solution densities were calculated from

a calculated $\mathrm{Na}^{+}$molarity, $\left[\mathrm{Na}^{+}\right]_{\text {calc }}$, using Equation $2 \mathrm{~b}$ derived by Walker and Coleman ${ }^{39}$ for $\mathrm{H}$-Canyon waste solutions at $25^{\circ} \mathrm{C}$.

\footnotetext{
$\dagger$ Wilmarth analyzed for $\mathrm{NO}_{2}, \mathrm{NO}_{3}$, and $\mathrm{OH}^{-}$for one surface dip sample taken in September, 2000 at a height of 250" from the tank bottom 12
} 
WSRC-TR-2001-00155, Rev. 1

$$
m=M\left(\frac{\text { weight solution }}{(\text { weight } \text { solution }- \text { total weight solutes })}\right)\left(\frac{1}{\text { density }_{\text {calc }}}\right)
$$

where $\mathrm{m}=$ molality

$$
\begin{aligned}
& \mathrm{M}=\text { molarity } \\
& \text { weight solutes }=\frac{\text { dissolved solids }(\mathrm{g} / \mathrm{L})}{1000 \mathrm{~L}}
\end{aligned}
$$

$$
\begin{gathered}
\mathrm{Al}(\mathrm{OH})_{4}^{-}+\mathrm{Cl}^{-}+\mathrm{CO}_{3}^{-2}+\mathrm{C}_{2} \mathrm{O}_{4}^{-2}+\mathrm{F}^{-}+\mathrm{NO}_{2}^{-}+\mathrm{NO}_{3}^{-} \\
\text {dissolved solids }=+\mathrm{OH}^{-}+\mathrm{PO}_{4}^{-3}+\mathrm{SO}_{4}^{-2}+\mathrm{Fe}(\mathrm{OH})_{4}^{-}+\mathrm{K}^{+}+\mathrm{H}_{2} \mathrm{SiO}_{4}^{-2}+ \\
\mathrm{UO}_{2}(\mathrm{OH})_{\frac{7}{3}}+\left[\mathrm{Na}_{\text {calc }}^{+}\right] \\
\text {density }_{\text {calc }} \equiv \rho=1.0133+0.040469\left[\mathrm{Na}^{+}\right]_{\text {calc }}
\end{gathered}
$$

where $\rho$ is the calculated solution density in $\mathrm{g} / \mathrm{cm}^{3}$ and $\left[\mathrm{Na}^{+}\right]_{\text {calc }}$ is the calculated molar $\mathrm{Na}^{+}$concentration from Equation $2 \mathrm{c}$.

$$
\begin{aligned}
& \mathrm{Na}_{\text {calc }}^{+}=\mathrm{NaAl}(\mathrm{OH})_{4}+\mathrm{NaCl}+\mathrm{Na}_{2} \mathrm{CO}_{3}+\mathrm{Na}_{2} \mathrm{C}_{2} \mathrm{O}_{4}+\mathrm{NaF}+ \\
& \mathrm{NaNO}_{2}+\mathrm{NaNO}_{3}+\mathrm{NaOH}+\mathrm{Na}_{3} \mathrm{PO}_{4}+\mathrm{Na}_{2} \mathrm{SO}_{4}+\mathrm{NaFe}(\mathrm{OH})_{4}^{-} \\
& -\mathrm{KOH}+\mathrm{Na}_{2} \mathrm{H}_{2} \mathrm{SiO}_{4}+\mathrm{Na}\left(\mathrm{UO}_{2}\right)_{3}(\mathrm{OH})_{7}
\end{aligned}
$$

The molal contributions from $\mathrm{CO}_{3}$ and $\mathrm{C}_{2} \mathrm{O}_{4}$ were summed as a total $\mathrm{CO}_{3}$ contribution while the $\mathrm{NO}_{2}$ and $\mathrm{NO}_{3}$ were summed as $\mathrm{NO}_{3}$ since Geochemist's Workbench can only accommodate one carbon and one nitrogen species at a time.

In addition to reporting molar concentrations, Table III and Table IV compare calculated and measured solution densities. Solution densities were calculated from Equation $2 b$. Generally, measured and calculated densities agreed within 2-3\%. Two measured densities for Tank 30, however, were much lower than predicted from the measured salt concentrations. It was assumed that these density measurements were in error but the actual measured values are shown in Table IV for comparison.

For one Tank 32 dip sample at a tank elevation of 90 inches, the measured $\mathrm{Na}^{+}$ concentration was significantly lower than would be predicted by the measured density or the measured anion concentrations. A calculated $\mathrm{Na}^{+}$concentration was substituted for this measured concentration. The concentration was calculated by multiplying the measured $\mathrm{Na}^{+}$concentration for a dip sample taken on the same date at a tank elevation of 120 inches by the ratio of the partial densities of dissolved solids for these two measurements. The calculation took the form 


$$
\left[\mathrm{Na}^{+}\right]_{2}=\left[\mathrm{Na}^{+}\right]_{1} \frac{\rho_{\text {meas }, 2}-1.0133}{\rho_{\text {meas }, 1}-1.0133}
$$

where $\rho_{\text {meas }}$ is the measured density and subscripts 1 and 2 refer to the two sets of measurements.

\subsection{Quality of Analytic Data}

The SRTC and the F-area laboratory both analyzed samples taken on 12/5/00 from Tank 30 which was just after the transfer of the ESP washwater from Tank 40. Note that the Farea laboratory sample was a surface dip sample and the reported $\mathrm{Si}$ concentration is 78.7 ppm (see Table II). The SRTC laboratory analyzed samples taken on the same day at 170 ", 200" and 240" above the bottom of the tank. The SRTC laboratory analyses are reported as 9.4, 9.7, and $12.4 \mathrm{ppm}$.

The SRTC and the F-area laboratory both dilute the original sample in order to handle the radioactive samples safely in a radioactive hood and match the $\mathrm{Na}$ concentration to the instrument range. The F-area laboratory uses two dilutions, one $21 \mathrm{X}$ and one $10 \mathrm{X}$. If the true Si concentration is between 9.4 and 12.4 as measured by SRTC, then the combined $210 \mathrm{X}$ dilution done by F-Area laboratory puts the Si concentration at or close to the detection limit of the inductively coupled plasma (ICP) technique employed for measurement, e.g. 9.4ppm/210 and $12.4 / 210=0.045-0.059 \mathrm{ppm}$ in the solution at this dilution while the instrument detection limit is in the $0.2 \mathrm{ppm}$ range for $\mathrm{Si}$ in the $4 \mathrm{M}$ $\mathrm{HNO}_{3}$ solutions analyzed. $\neq$ Measurements taken at or below the detection limit of an analytic instrument can be in error by $100-300 \%$. When this error is multiplied by the dilution factor it is magnified into a larger error. Hence, the F-Area laboratory Si analyses are $\sim 7 \mathrm{X}$ larger than those of the SRTC analyses.

\footnotetext{
$\ddagger$ Mark Jones (F-Area Laboratory on April 5, 2001)
} 


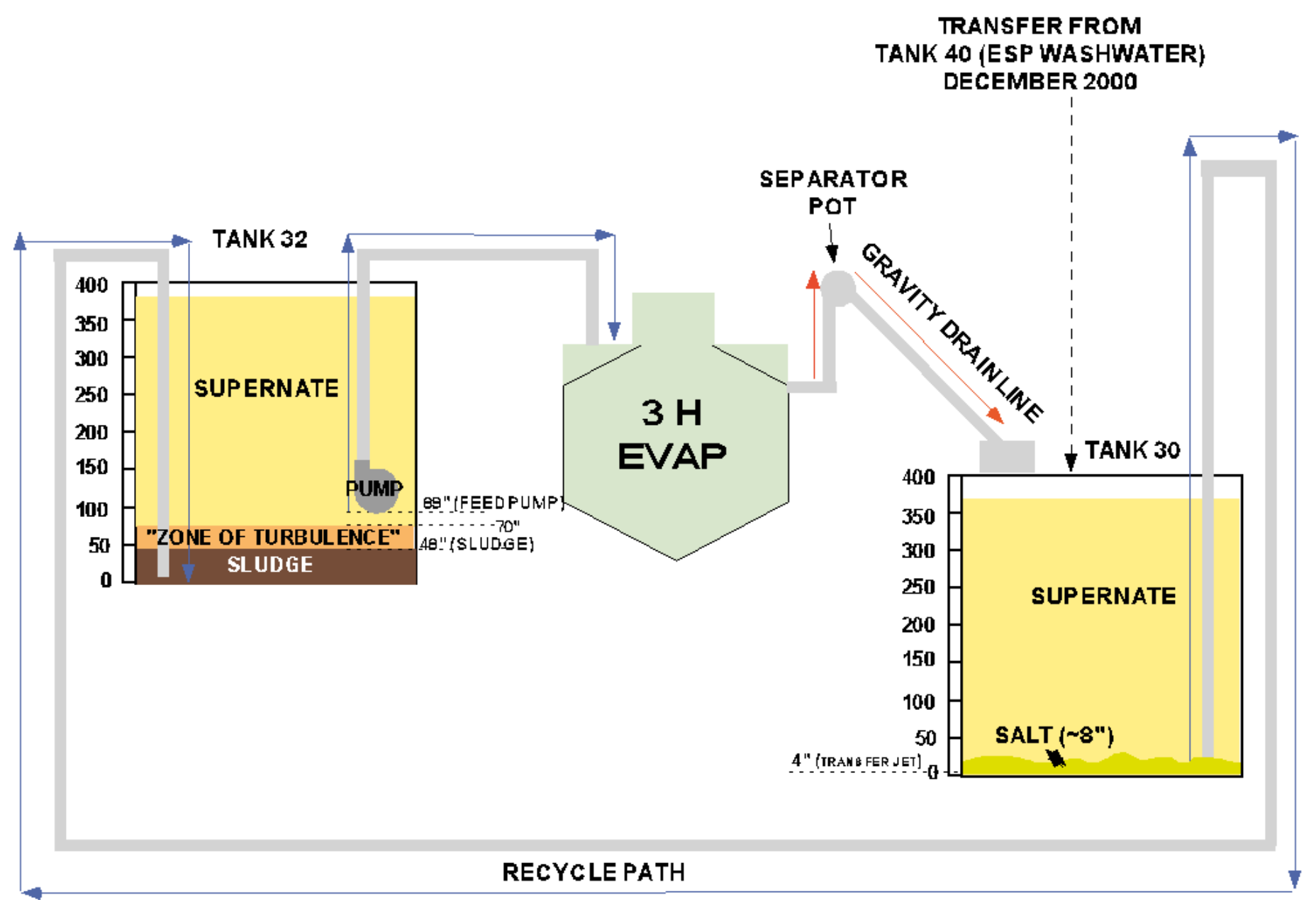

Figure 3. Schematic of the SRS 3H Evaporator, the feed tank (Tank 32) and the drop tank (Tank 30).

Note that the feed pump in Tank 32 is at a height of 89" and that the sludge layer is at a height of 48 " from the bottom of the tank. Note that Tank 30 does not have a feed pump and has an $~ 8$ " salt layer. Tank 30 had a transfer jet located 4" from the bottom of the tank for the time period examined in this study. 


\section{WSRC-TR-2001-00155, Rev. 1}

SRTC has developed a method by which the entire diluted sample is filtered so that the total amount of Si (both soluble and colloidal) can be more accurately determined. A liter of solution is filtered. The filtrate, representing the soluble silica, is homogeneous and can be accurately measured by ICP. The colloidal silica on the filter is dissolved and measured separately. The two are added together for a final total silica analysis that is representative of an entire liter of sample $e^{36,37,38}$ rather than a few milliliters of solution. The quality of the SRTC analyses is evidenced in Table II by the consistency of the surface and dip sample analyses for Tanks 30 and 32.

Recently, Coleman ${ }^{40}$ has tested a spectrophotometric method from the 1920's that uses molybdic acid to analyze simultaneously for the monosilicic acid in solution, the polysilicic acids, and colloids. Coleman's analyses have verified Wilmarth's analytic results. Because of the high bias in the F-area laboratory Si analyses, only the Si analyses reported by Wilmarth were used for modeling, e.g. the F-area analyses (\#200138614 and \#200125277 for Tank 32 and \#200125276 for Tank 30) were not used and are shown in cyan in Table III and Table IV.

\subsection{Analytic Data Populations}

\subsubsection{Tank 32H (Feed Tank)}

The chemical data for Tank 32 given in Table III was taken at various times and at various depths within the tank. The chemistry of the samples taken within 6" of the sludge layer, at a height of 54" ( 35 " below the height of the feed pump), was distinctly different than the chemistry of the remaining supernate samples higher in the tank as illustrated in Figure 4. Since the feed pump cannot process liquid from the 54" height a decision was made to not model this depth data.

The chemistry of the supernate above the feed pump looked somewhat different from the chemistry of the supernate at the feed pump (at a height of 90") and 20" below the feed pump (at a height of 70"). These supernate samples were split into two depth regimes, e.g. dip samples and variable depth samples (VDS), to assess if the chemistry differences observed in Table III made a difference in the saturation with respect to the aluminosilicate NAS phase. The VDS samples spanned from 70" above the tank bottom to 120 " above the tank bottom.

Modeling different depth regimes in the feed tank provided an average chemistry for each depth. The average chemistry is needed for modeling the phase boundaries on the activity diagrams. Once the boundaries are defined by this average chemistry, then the position of the data taken on different days and at different depths can be overlain. Modeling the Tank 32 data as different depth populations also facilitates the interpretation of whether colloidal silica or unsettled entrained sludge solids are skewing the interpretation of the data. 
Samples Taken August, 2000

(before a recycle)

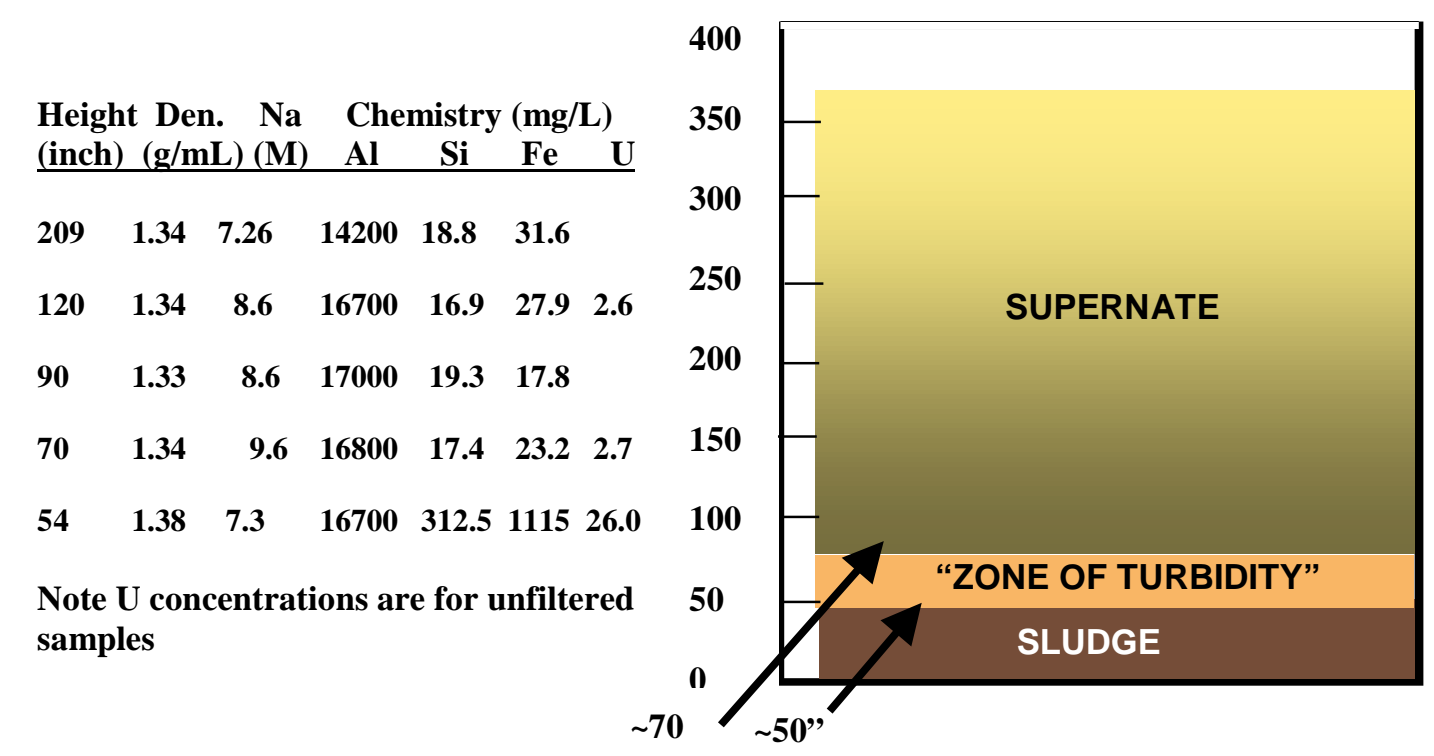

Samples Taken September, 2000

(after a recycle)

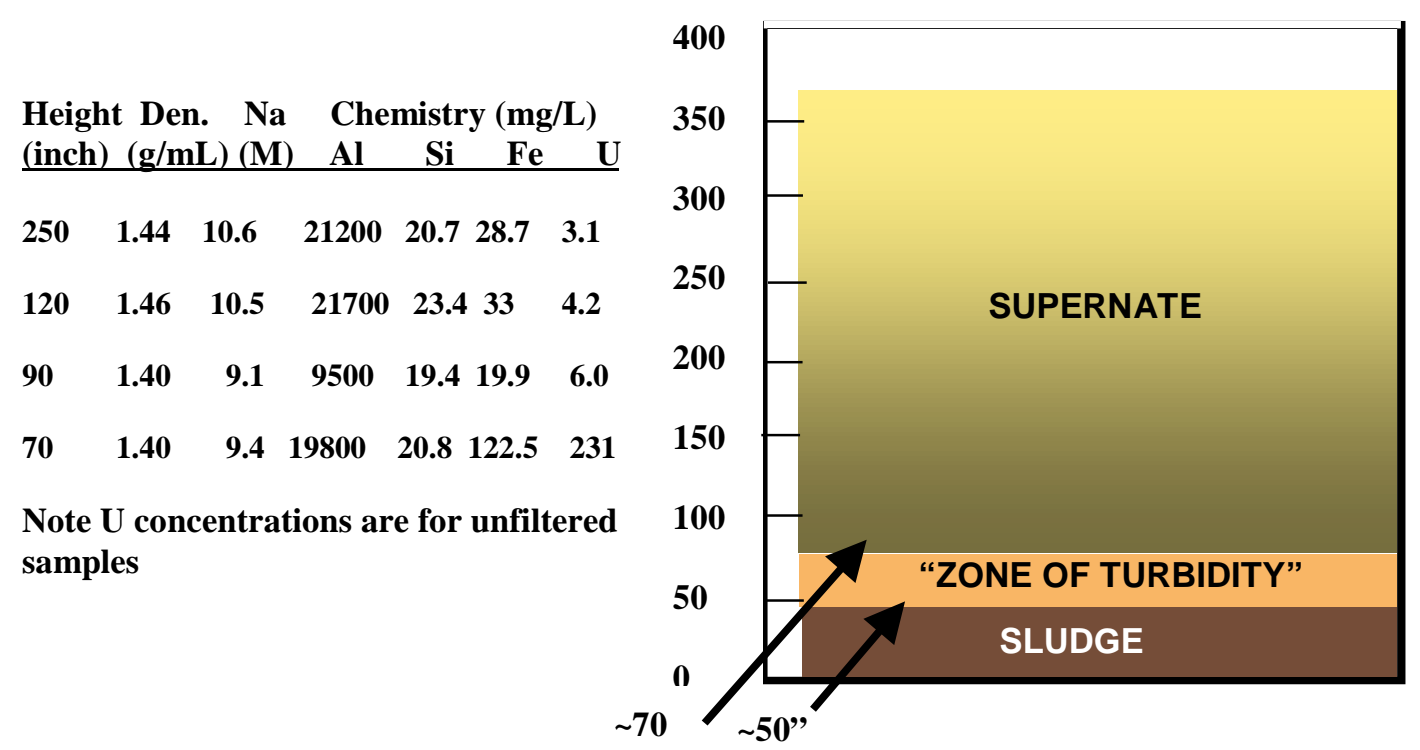

Figure 4. Delineation of depth populations in the SRS 3H Evaporator Feed Tank (Tank 32). 
The first depth population defined for Tank 32 samples (Table III) consists of dip sample analyses taken at various heights in the supernate (see Figure 4). Six analyses were available spanning a time frame between February 2000 and February 2001. The two most recent samples had been analyzed by the F-area laboratory and were biased high as indicated in Section 4.3 (see also Table II and Table III). These data were not used in modeling. The data used for modeling, therefore, spans from February 2000 to September 2000.

The second depth population consists of all Tank 32 variable depth samples taken from 70 " above the tank bottom to 120 " below the tank bottom. This range spans the height 30 " above the feed pump and 20" below the feed pump. All of the VDS data in the 70120 " depth interval was used in modeling. The data spans from February 2000 to September 2000. The data includes two samples from February 2000 that had been taken within a few hours of a Tank 30 to Tank 32 transfer and data from August/September 2000 that had been made before and after a Tank 30 to Tank 32 transfer. While several of the February and September 2000 samples appear high in silica, removal of these 8 samples from this depth population would have left only three samples from August/September 2000. During modeling the before and after recycle samples were plotted as different symbols (and colors) to draw attention to their relative positions on the activity diagrams.

The last depth population is defined between the surface of the sludge (48") and <70" above the tank bottom. There is only one VDS from this region, the sample taken at 54" that was not modeled. This zone is hereafter referred to as the "zone of turbidity (ZOT)" as shown in Figure 4 since the chemistry of the solutions in this region of the tank can be affected by turbulence from the following sources:

- turbulent eddies of sludge that may be stirred up when recycle transfers are injected below the sludge layer every 4-6 weeks

- influence from feed pump turbulence during transfers out of the tank and into the evaporator

- potential for silica rich sol accumulation layer, a layer which will not settle because silica sols are hydrophobic and the silica colloids repel each other ${ }^{41}$ and remain suspended for long periods of time (see Figure 5). 

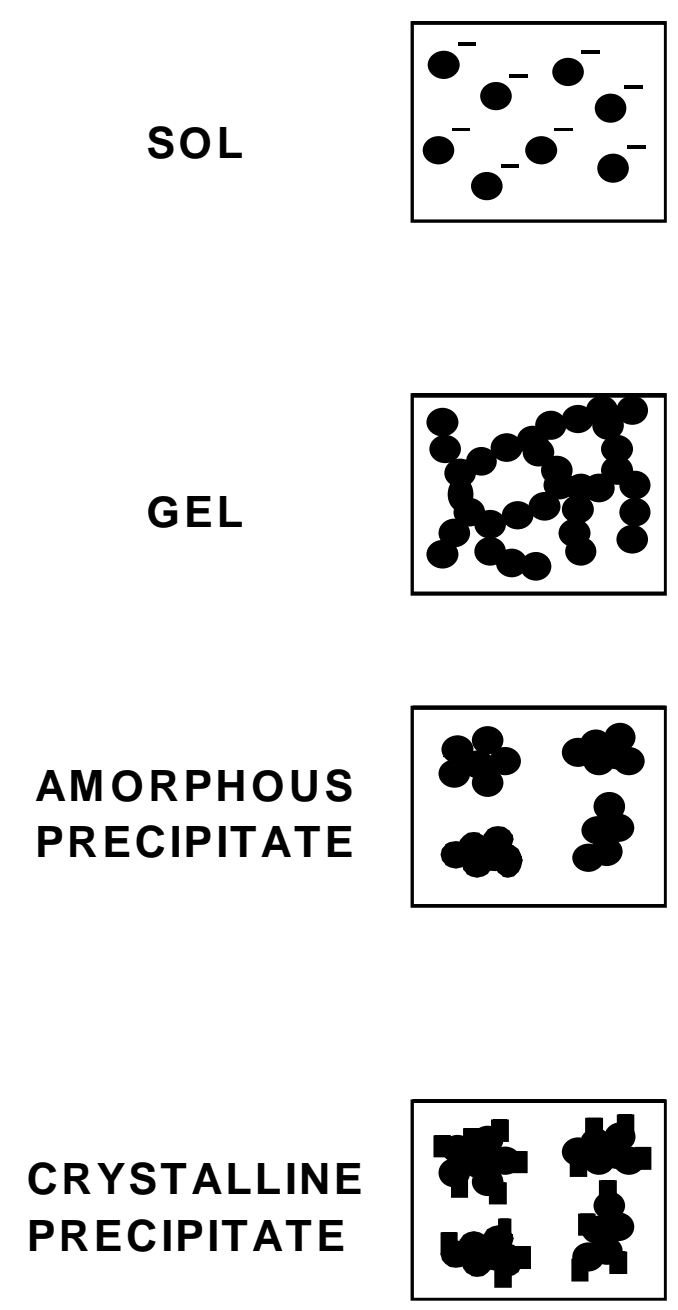

Figure 5. Pictorial diagram showing the differences between a sol, gel, and precipitate (after references 41 and 42). 
WSRC-TR-2001-00155, Rev. 1

Table II. Transfer and Recycle Frequency and Si Analysis for the SRS 3H Evaporator

\begin{tabular}{|c|c|c|c|c|c|c|c|c|c|c|c|c|c|c|}
\hline & $\begin{array}{c}\text { Feb } \\
2000\end{array}$ & $\begin{array}{l}\text { Mar } \\
2000\end{array}$ & $\begin{array}{c}\text { Apr } \\
2000\end{array}$ & $\begin{array}{c}\text { May } \\
2000 \\
\text { (New } \\
3 H \\
\text { Pot) } \\
\end{array}$ & $\begin{array}{l}\text { June } \\
2000\end{array}$ & $\begin{array}{l}\text { July } \\
2000\end{array}$ & $\begin{array}{l}\text { Aug } \\
2000\end{array}$ & $\begin{array}{l}\text { Sept } \\
2000\end{array}$ & $\begin{array}{c}\text { Oct } \\
2000\end{array}$ & $\begin{array}{l}\text { Nov } \\
2000\end{array}$ & $\begin{array}{c}\text { Dec } \\
2000\end{array}$ & $\begin{array}{c}\text { Jan } \\
2001\end{array}$ & $\begin{array}{c}\text { Feb } \\
2001\end{array}$ & $\begin{array}{l}\text { Mar } \\
2001\end{array}$ \\
\hline \multicolumn{15}{|c|}{ Feed and Recycle Frequency to Tanks 32 (Feed Tank) and 30 (Drop Tank) } \\
\hline $\begin{array}{c}\text { Trans- } \\
\text { fers } \\
\text { into } \\
\text { T32 }\end{array}$ & $\begin{array}{c}2 / 15 \\
\text { from } \\
\text { T30 } \\
\text { (184,000 } \\
\text { gallons) }\end{array}$ & & & & $\begin{array}{c}6 / 30 \\
\text { from } \\
\mathrm{T} 30 \\
(230,000 \\
\text { gallons) }\end{array}$ & $\begin{array}{c}7 / 29 \\
\text { from } \\
\text { T30 } \\
\text { (607,000 } \\
\text { gallons) }\end{array}$ & $\begin{array}{c}8 / 22 \\
\text { from } \\
\mathrm{T} 30 \\
\text { (526,000 } \\
\text { gallons) }\end{array}$ & $\begin{array}{c}9 / 3 \\
\text { from } \\
\mathrm{T} 30 \\
(695,000 \\
\text { gallons })\end{array}$ & $\begin{array}{c}10 / 25 \\
\text { from } \\
\mathrm{T} 30 \\
(993,000 \\
\text { gallons) }\end{array}$ & & & $\begin{array}{c}1 / 18 \\
\text { from } \\
\mathrm{T} 30 \\
(249,000 \\
\text { gallons })\end{array}$ & & Ongoing \\
\hline $\begin{array}{c}\text { Trans- } \\
\text { fers } \\
\text { into } \\
\text { T30 }\end{array}$ & & & & & & & & & & & $\begin{array}{c}12 / 5 \\
\text { from } \\
\mathrm{T} 40 \\
(379,000 \\
\text { gallons) }\end{array}$ & & & \\
\hline \multicolumn{15}{|c|}{ Si Analyses (ppm) for Tank 32 (Feed Tank) } \\
\hline F-Area & & & & & & & & & & & $53.4^{\dagger}$ & & $59^{\dagger}$ & \\
\hline SRTC & $15.5 *+$ & & & & & & $\begin{array}{c}18.7^{\ddagger} \\
16.9 \\
19.3 \\
17.4 \\
\end{array}$ & $\begin{array}{c}20.7^{\ddagger} \\
23.4 \\
19.4 \\
20.8 \\
\end{array}$ & & & & & & \\
\hline \multicolumn{15}{|c|}{ Si Analyses (ppm) for Tank 30 (Drop Tank) } \\
\hline F-Area & & & & & & & & & & & $78.7^{\ddagger}$ & & & \\
\hline SRTC & $15.5 *$ & & & & & & $\begin{array}{l}10.4^{\ddagger} \\
23.5\end{array}$ & & & & $\begin{array}{c}12.4^{\ddagger} \\
9.4 \\
9.7\end{array}$ & & & \\
\hline
\end{tabular}

\$ Dip samples, remaining are variable depth samples (VDS) as discussed in text

*Calculated from minimum detection limit 
WSRC-TR-2001-00155, Rev. 1

Table III. Available Tank 32 Analytic Data Including Si for SRS 3H Evaporator Feed Tank

\begin{tabular}{|c|c|c|c|c|c|c|c|c|c|c|c|c|c|c|c|c|c|c|c|c|c|}
\hline Date & $\begin{array}{l}\text { Description/ } \\
\text { Reference }\end{array}$ & $\begin{array}{l}\text { Height } \\
\text { (inchs) }\end{array}$ & $\begin{array}{c}\text { Al } \\
(\mathbf{M})\end{array}$ & $\begin{array}{c}\mathrm{C}_{2} \mathbf{O}_{4} \\
(\mathbf{M})\end{array}$ & $\begin{array}{c}\mathbf{C l} \\
(\mathrm{M})\end{array}$ & $\begin{array}{l}\mathrm{CO}_{3} \\
(\mathrm{M})\end{array}$ & $\begin{array}{c}\mathbf{F} \\
(\mathbf{M})\end{array}$ & $\begin{array}{l}\mathrm{NO}_{2} \\
(\mathrm{M})\end{array}$ & $\begin{array}{l}\mathrm{NO}_{3} \\
(\mathrm{M})\end{array}$ & $\begin{array}{l}\text { OH } \\
(\mathbf{M})\end{array}$ & $\begin{array}{l}\mathrm{PO}_{4} \\
(\mathrm{M})\end{array}$ & $\begin{array}{l}\mathrm{SO}_{4} \\
(\mathrm{M})\end{array}$ & $\begin{array}{l}\mathbf{F e} \\
(\mathrm{M})\end{array}$ & $\underset{(\mathbf{M})}{\mathbf{K}}$ & $\begin{array}{c}\mathbf{S i} \\
(\mathbf{M})\end{array}$ & $\begin{array}{c}\mathrm{U} \\
(\mathbf{M})\end{array}$ & $\begin{array}{c}\mathrm{Na} \\
\text { Calc } \\
\text { (M) }\end{array}$ & $\begin{array}{c}\text { Na } \\
\text { Meas } \\
(\mathbf{M}) \\
\end{array}$ & $\begin{array}{c}\text { wt } \\
\text { salt, } \\
\text { g/L }\end{array}$ & $\begin{array}{c}\text { Densc } \\
\text { alc } \\
\text { g/ml }\end{array}$ & $\begin{array}{c}\text { Dens } \\
\text { meas } \\
\text { g/ml }\end{array}$ \\
\hline \multicolumn{22}{|c|}{ Dip Samples (Tank surface) } \\
\hline $02 / 15 / 01$ & 200138614 & dip & 0.76 & $90 \mathrm{E}-03$ & 10E-02 & $00 \mathrm{E}-02$ & $5.40 \mathrm{E}-03$ & 1.83 & 1.76 & .56 & $30 \mathrm{E}-03$ & $.11 \mathrm{E}-02$ & $37 \mathrm{E}-04$ & $5.00 \mathrm{E}-02$ & $2.10 \mathrm{E}-03$ & $.56 \mathrm{E}-05$ & 8.99 & & 56.22 & 1.38 & 1.45 \\
\hline $12 / 5 / 00$ & 200125277 & dip & 0.85 & $2.85 \mathrm{E}-03$ & $1.25 \mathrm{E}-02$ & $1.00 \mathrm{E}-02$ & $4.03 \mathrm{E}-03$ & 1.86 & 2.82 & 4.86 & $8.80 \mathrm{E}-03$ & $1.91 \mathrm{E}-02$ & $2.37 \mathrm{E}-04$ & $5.30 \mathrm{E}-02$ & $1.90 \mathrm{E}-03$ & $1.93 \mathrm{E}-05$ & 10.45 & & 670.60 & 1.44 & 1.43 \\
\hline $09 / 4 / 00$ & surface dip ${ }^{*}$ & 250 & 0.79 & $2.90 \mathrm{E}-03$ & $1.18 \mathrm{E}-02$ & $2.00 \mathrm{E}-02$ & 4.03E-03 & 1.44 & 3.42 & 4.86 & $8.05 \mathrm{E}-03$ & $1.51 \mathrm{E}-02$ & $1.43 \mathrm{E}-05$ & $5.15 \mathrm{E}-02$ & 7.37E-04 & $1.85 \mathrm{E}-05$ & 10.58 & 10.57 & 685.31 & 1.44 & 1.38 \\
\hline $08 / 21 / 00$ & surface dip ${ }^{t}$ & 209 & 0.53 & $2.85 \mathrm{E}-03$ & $1.18 \mathrm{E}-02$ & $2.00 \mathrm{E}-02$ & $4.03 \mathrm{E}-03$ & 0.84 & 1.39 & 4.45 & $8.05 \mathrm{E}-03$ & $1.51 \mathrm{E}-02$ & $5.66 \mathrm{E}-04$ & $5.15 \mathrm{E}-02$ & $6.68 \mathrm{E}-04$ & $1.85 \mathrm{E}-05$ & 7.27 & 7.26 & 423.94 & 1.31 & 1.34 \\
\hline $02 / 1 / 00$ & TK32H-S $1^{\mathrm{t}}$ & dip & 0.56 & $2.85 \mathrm{E}-03$ & $1.18 \mathrm{E}-02$ & $2.00 \mathrm{E}-02$ & $4.03 \mathrm{E}-03$ & 1.05 & 1.62 & 3.37 & $8.05 \mathrm{E}-03$ & $1.51 \mathrm{E}-02$ & $1.81 \mathrm{E}-04$ & $5.15 \mathrm{E}-02$ & $2.85 \mathrm{E}-04$ & $1.22 \mathrm{E}-05$ & 6.66 & 6.66 & 418.38 & 1.28 & 1.28 \\
\hline $02 / 1 / 00$ & TK32H-S1 ${ }^{\mathrm{t}}$ & $\operatorname{dip}$ & 0.57 & $2.85 \mathrm{E}-03$ & $1.18 \mathrm{E}-02$ & $2.00 \mathrm{E}-02$ & $4.03 \mathrm{E}-03$ & 1.07 & 1.66 & 3.46 & $8.05 \mathrm{E}-03$ & $1.51 \mathrm{E}-02$ & $1.86 \mathrm{E}-04$ & $5.15 \mathrm{E}-02$ & $2.85 \mathrm{E}-04$ & $1.18 \mathrm{E}-05$ & 6.84 & 6.83 & 429.22 & 1.29 & 1.28 \\
\hline \multicolumn{22}{|c|}{ Variable Depth Samples 70-120" From Tank Bottom In Vicinitv of Feed Pump (89" From Bottom) } \\
\hline $09 / 4 / 00$ & $120^{\prime \prime}$ & 120 & 0.80 & $2.85 \mathrm{E}-03$ & $1.18 \mathrm{E}-02$ & $2.00 \mathrm{E}-02$ & 4.03E-03 & 1.57 & 2.91 & 5.15 & $8.05 \mathrm{E}-03$ & $1.51 \mathrm{E}-02$ & $5.91 \mathrm{E}-04$ & $5.15 \mathrm{E}-02$ & $8.33 \mathrm{E}-04$ & $2.45 \mathrm{E}-05$ & 10.49 & 10.48 & 663.85 & 1.44 & 1.46 \\
\hline $09 / 4 / 00$ & $90^{\prime *}$ & 90 & 0.35 & $2.85 \mathrm{E}-03$ & $1.18 \mathrm{E}-02$ & $2.00 \mathrm{E}-02$ & $4.03 \mathrm{E}-03$ & 1.24 & 3.25 & 4.18 & $8.05 \mathrm{E}-03$ & $1.51 \mathrm{E}-02$ & $3.56 \mathrm{E}-04$ & $5.15 \mathrm{E}-02$ & $6.91 \mathrm{E}-04$ & $9.71 \mathrm{E}-04$ & 9.08 & $9.07 f$ & 578.28 & 1.38 & 1.40 \\
\hline $09 / 4 / 00$ & $70^{\prime *}$ & 70 & 0.73 & $2.85 \mathrm{E}-03$ & $1.18 \mathrm{E}-02$ & $2.00 \mathrm{E}-02$ & $4.03 \mathrm{E}-03$ & 1.25 & 3.13 & 4.23 & $8.05 \mathrm{E}-03$ & $1.51 \mathrm{E}-02$ & $2.19 \mathrm{E}-03$ & $5.15 \mathrm{E}-02$ & 7.39E-04 & $2.83 \mathrm{E}-05$ & 9.41 & 9.40 & 616.16 & 1.39 & 1.40 \\
\hline $08 / 21 / 00$ & $120^{\prime \prime}$ & 120 & 0.62 & $2.85 \mathrm{E}-03$ & $1.18 \mathrm{E}-02$ & $2.00 \mathrm{E}-02$ & $4.03 \mathrm{E}-03$ & 0.95 & 1.74 & 5.21 & $8.05 \mathrm{E}-03$ & $1.51 \mathrm{E}-02$ & $5.00 \mathrm{E}-04$ & $5.15 \mathrm{E}-02$ & $6.00 \mathrm{E}-04$ & $1.45 \mathrm{E}-05$ & 8.58 & 8.57 & 502.10 & 1.36 & 1.34 \\
\hline $08 / 21 / 00$ & $90^{\prime \prime}$ & 90 & 0.63 & $2.85 \mathrm{E}-03$ & $1.18 \mathrm{E}-02$ & $2.00 \mathrm{E}-02$ & $4.03 \mathrm{E}-03$ & 1.06 & 1.82 & 5.00 & $8.05 \mathrm{E}-03$ & $1.51 \mathrm{E}-02$ & $3.19 \mathrm{E}-04$ & $5.15 \mathrm{E}-02$ & $6.87 \mathrm{E}-04$ & $9.71 \mathrm{E}-04$ & 8.58 & 8.57 & 510.23 & 1.36 & 1.33 \\
\hline $08 / 21 / 00$ & $70^{\prime \prime} \mathrm{t}$ & 70 & 0.62 & $2.85 \mathrm{E}-03$ & $1.18 \mathrm{E}-02$ & $2.00 \mathrm{E}-02$ & $4.03 \mathrm{E}-03$ & 0.95 & 1.75 & 5.24 & $8.05 \mathrm{E}-03$ & $1.51 \mathrm{E}-02$ & $4.15 \mathrm{E}-04$ & $5.15 \mathrm{E}-02$ & $6.20 \mathrm{E}-04$ & $1.54 \mathrm{E}-05$ & 8.62 & 8.61 & 504.66 & 1.36 & 1.34 \\
\hline $02 / 1 / 00$ & TK32H-S1 ${ }^{*}$ & 89 & 0.56 & $2.85 \mathrm{E}-03$ & $1.18 \mathrm{E}-02$ & $2.00 \mathrm{E}-02$ & $4.03 \mathrm{E}-03$ & 0.92 & 2.00 & 3.69 & $8.05 \mathrm{E}-03$ & $1.51 \mathrm{E}-02$ & $2.51 \mathrm{E}-04$ & $5.15 \mathrm{E}-02$ & $9.83 \mathrm{E}-04$ & $1.60 \mathrm{E}-05$ & 7.23 & 7.22 & 454.74 & 1.31 & 1.30 \\
\hline $02 / 1 / 00$ & TK32H-S1 ${ }^{*}$ & 89 & 0.52 & $2.85 \mathrm{E}-03$ & $1.18 \mathrm{E}-02$ & $2.00 \mathrm{E}-02$ & $4.03 \mathrm{E}-03$ & 0.86 & 1.88 & 3.47 & $8.05 \mathrm{E}-03$ & $1.51 \mathrm{E}-02$ & $3.31 \mathrm{E}-04$ & $5.15 \mathrm{E}-02$ & $9.04 \mathrm{E}-04$ & $1.51 \mathrm{E}-05$ & 6.79 & 6.79 & 426.98 & 1.29 & 1.27 \\
\hline \multicolumn{22}{|c|}{ Historic Samples } \\
\hline $11 / 24 / 92$ & 199674 & $\operatorname{dip}$ & 0.40 & $6.25 \mathrm{E}-03$ & 5.95E-03 & $5.00 \mathrm{E}-03$ & $1.00 \mathrm{E}-02$ & 1.10 & 3.05 & 1.95 & $3.00 \mathrm{E}-03$ & $6.05 \mathrm{E}-02$ & $3.58 \mathrm{E}-06$ & $1.90 \mathrm{E}-02$ & $2.14 \mathrm{E}-05$ & 1.07E-05 & 6.64 & 5.30 & 471.32 & 1.28 & 1.29 \\
\hline
\end{tabular}

$*=$ after recycle of Tank 30 to $32 ; \mathrm{t}=$ before recycle of Tank 30 to $32 ; * *=$ within a few hours after recycle of Tank 30 to Tank 32 at height of the feed pump (89"). Notes: data indicated in green was recalculated to match the measured and calculated $\mathrm{Na}^{+}$concentrations; data indicated in yellow was missing data that was estimated from historic measurements; magenta values for $\mathrm{Na}^{+}$molarities are calculated based on adjustments to the $\mathrm{OH}^{-}, \mathrm{NO}_{3}^{-}$, and $\mathrm{NO}_{2}^{-}$and are shown to agree well with the measured Na concentrations; data indicated in gray are below detection limit (BDL) and $1 / 2$ the detection limit has been substituted; $f=$ calculated from measured density according to Equation 3. 
WSRC-TR-2001-00155, Rev. 1

Table IV. Available Tank 30 Analytic Data Including Si for SRS 3H Evaporator Drop Tank

\begin{tabular}{|c|c|c|c|c|c|c|c|c|c|c|c|c|c|c|c|c|c|c|c|c|c|}
\hline Date & $\begin{array}{l}\text { Description/ } \\
\text { Reference }\end{array}$ & \begin{tabular}{|l|} 
Height \\
(inchs)
\end{tabular} & $\begin{array}{c}\text { Al } \\
(\mathbf{M})\end{array}$ & $\begin{array}{c}\mathrm{Cl} \\
(\mathrm{M})\end{array}$ & $\begin{array}{c}\mathrm{C}_{2} \mathrm{O}_{4} \\
(\mathrm{M})\end{array}$ & $\begin{array}{l}\mathrm{CO}_{3} \\
(\mathrm{M})\end{array}$ & $\begin{array}{c}\mathbf{F} \\
(\mathbf{M})\end{array}$ & $\begin{array}{l}\mathrm{NO}_{2} \\
(\mathrm{M})\end{array}$ & $\begin{array}{l}\mathrm{NO}_{3} \\
(\mathrm{M})\end{array}$ & $\begin{array}{l}\text { OH } \\
(\mathbf{M})\end{array}$ & $\begin{array}{l}\mathbf{P O}_{4} \\
\text { (M) }\end{array}$ & $\begin{array}{l}\mathrm{SO}_{4} \\
(\mathrm{M})\end{array}$ & $\begin{array}{c}\mathbf{F e} \\
(\mathbf{M})\end{array}$ & $\begin{array}{c}\mathbf{K} \\
(\mathbf{M})\end{array}$ & $\begin{array}{c}\mathbf{S i} \\
(\mathbf{M})\end{array}$ & $\begin{array}{c}\mathbf{U} \\
(\mathbf{M})\end{array}$ & $\begin{array}{c}\mathrm{Na} \\
\text { Calc } \\
(\mathbf{M}) \\
\end{array}$ & \begin{tabular}{|c|} 
Na \\
Meas \\
$(\mathbf{M})$ \\
\end{tabular} & $\begin{array}{c}\text { wt } \\
\text { salt, } \\
\text { g/L } \\
\end{array}$ & \begin{tabular}{|c|} 
Densc \\
alc \\
g/ml \\
\end{tabular} & $\begin{array}{c}\text { Dens } \\
\text { meas } \\
\text { g/ml } \\
\end{array}$ \\
\hline \multicolumn{22}{|c|}{ Dip (Tank surface) and Variable Depth Supernate Samples } \\
\hline $12 / 01 / 00$ & 200125276 & surface & 0.74 & $1.49 \mathrm{E}-02$ & $5.00 \mathrm{E}-03$ & $2.85 \mathrm{E}-03$ & $2.65 \mathrm{E}-03$ & 2.09 & 3.03 & 4.44 & $9.10 \mathrm{E}-03$ & $1.59 \mathrm{E}-02$ & 5.59E-04 & $6.10 \mathrm{E}-02$ & $2.80 \mathrm{E}-03$ & $3.11 \mathrm{E}-05$ & 10.34 & . & 673.79 & 1.43 & 1.47 \\
\hline $12 / 01 / 00$ & $\begin{array}{l}\text { lof } 3 \\
\text { nonroutine }\end{array}$ & 240 & 0.80 & $1.49 \mathrm{E}-02$ & $5.00 \mathrm{E}-03$ & $2.85 \mathrm{E}-03$ & $2.65 \mathrm{E}-03$ & 1.33 & 2.83 & 4.99 & $9.10 \mathrm{E}-03$ & $1.59 \mathrm{E}-02$ & $4.87 \mathrm{E}-03$ & $6.10 \mathrm{E}-02$ & $3.44 \mathrm{E}-04$ & $6.60 \mathrm{E}-05$ & 9.98 & & 633.57 & 1.42 & 1.44 \\
\hline $12 / 01 / 00$ & $\begin{array}{l}2 \text { of } 3 \\
\text { nonroutine }\end{array}$ & 200 & 0.79 & $1.49 \mathrm{E}-02$ & $5.00 \mathrm{E}-03$ & $2.85 \mathrm{E}-03$ & $2.65 \mathrm{E}-03$ & 1.35 & 2.85 & 4.96 & $9.10 \mathrm{E}-03$ & $1.59 \mathrm{E}-02$ & $3.68 \mathrm{E}-04$ & $6.10 \mathrm{E}-02$ & $3.35 \mathrm{E}-04$ & $4.30 \mathrm{E}-05$ & 9.99 & . & 634.27 & 1.42 & 1.14 \\
\hline $12 / 01 / 00$ & $\begin{array}{l}3 \text { of } 3 \\
\text { nonrouting } \\
\text { (surface) }\end{array}$ & 170 & 0.79 & $1.49 \mathrm{E}-02$ & $5.00 \mathrm{E}-03$ & $2.85 \mathrm{E}-03$ & $2.65 \mathrm{E}-03$ & 1.40 & 2.80 & 5.05 & $9.10 \mathrm{E}-03$ & $1.59 \mathrm{E}-02$ & $5.59 \mathrm{E}-04$ & $6.10 \mathrm{E}-02$ & $4.41 \mathrm{E}-04$ & $2.00 \mathrm{E}-05$ & 10.07 & & 636.73 & 1.42 & 1.08 \\
\hline $08 / 21 / 00$ & $\mathrm{Tk} 30 \mathrm{H}-\mathrm{S} 2$ & 179 & 0.79 & $1.49 \mathrm{E}-02$ & $5.00 \mathrm{E}-03$ & $2.85 \mathrm{E}-03$ & $2.65 \mathrm{E}-03$ & 1.39 & 2.95 & 5.17 & $9.10 \mathrm{E}-03$ & $1.59 \mathrm{E}-02$ & $3.65 \mathrm{E}-04$ & $6.10 \mathrm{E}-02$ & $8.35 \mathrm{E}-04$ & $4.37 \mathrm{E}-05$ & 10.34 & 10.35 & 653.84 & 1.43 & 1.41 \\
\hline $08 / 21 / 00$ & Tk30H-S1 & 348 & 0.79 & $1.49 \mathrm{E}-02$ & $5.00 \mathrm{E}-03$ & $2.85 \mathrm{E}-03$ & $2.65 \mathrm{E}-03$ & 1.66 & 2.79 & 4.54 & $9.10 \mathrm{E}-03$ & $1.59 \mathrm{E}-02$ & $5.55 \mathrm{E}-04$ & $6.10 \mathrm{E}-02$ & $3.69 \mathrm{E}-04$ & $1.77 \mathrm{E}-05$ & 9.81 & 9.83 & 633.15 & 1.41 & 1.40 \\
\hline $02 / 01 / 00$ & Tk30H-VDS & unknown & 0.64 & $1.49 \mathrm{E}-02$ & $5.00 \mathrm{E}-03$ & $2.85 \mathrm{E}-03$ & $2.65 \mathrm{E}-03$ & 1.31 & 2.78 & 4.87 & $9.10 \mathrm{E}-03$ & $1.59 \mathrm{E}-02$ & $8.67 \mathrm{E}-04$ & $6.10 \mathrm{E}-02$ & $6.41 \mathrm{E}-04$ & $2.23 \mathrm{E}-05$ & 9.64 & 9.66 & 604.27 & 1.40 & 1.34 \\
\hline \multicolumn{22}{|c|}{ Salt Samples } \\
\hline $8 / 21 / 00$ & VDS-Salt & 8 & 0.80 & 0.01 & & 0.02 & 0.01 & 1.99 & 4.23 & 7.46 & 0.01 & 0.02 & $4.84 \mathrm{E}-03$ & 0.06 & $1.43 \mathrm{E}-03$ & $6.60 \mathrm{E}-05$ & 14.53 & 14.53 & 897.71 & 1.60 & 1.68 \\
\hline \multicolumn{22}{|c|}{ Historic Samples } \\
\hline $11 / 24 / 92$ & 199672 & dip & 0.42 & $1.23 \mathrm{E}-02$ & $4.20 \mathrm{E}-01$ & $7.50 \mathrm{E}-03$ & $1.00 \mathrm{E}-02$ & 0.92 & 2.59 & 3.77 & $5.50 \mathrm{E}-03$ & $5.80 \mathrm{E}-02$ & $3.58 \mathrm{E}-06$ & $3.90 \mathrm{E}-02$ & $2.60 \mathrm{E}-03$ & $1.73 \mathrm{E}-05$ & 8.67 & & 539.86 & 1.36 & .1 .36 \\
\hline
\end{tabular}

Notes: data indicated in cyan was not used in modeling (see text); data indicated in green was recalculated to match the measured and calculated $\mathrm{Na}^{+}$ concentrations; data indicated in yellow was missing data that had to be estimated from historic measurements; magenta values for Na ${ }^{+}$molarities are calculated based on adjustments to the $\mathrm{OH}^{-}, \mathrm{NO}_{3}{ }^{-}$, and $\mathrm{NO}_{2}{ }^{-}$and are shown to agree well with the measured Na concentrations; data indicated in gray are below detection limit (BDL) and $1 / 2$ the detection limit has been substituted 
WSRC-TR-2001-00155, Rev. 1

Table V. Tank 32 Modeling Data for SRS 3H Evaporator Feed Tank

\begin{tabular}{|c|c|c|c|c|c|c|c|c|c|c|c|c|c|c|c|c|c|}
\hline Date & $\begin{array}{l}\text { Description/ } \\
\text { Reference }\end{array}$ & \begin{tabular}{|l|} 
Height \\
(inchs)
\end{tabular} & $\begin{array}{l}\text { Al } \\
(\mathbf{m})\end{array}$ & $\begin{array}{l}\text { Cl } \\
\text { (m) }\end{array}$ & $\begin{array}{l}\mathrm{CO}_{3} \\
(\mathrm{~m})\end{array}$ & $\begin{array}{c}\mathbf{F} \\
(\mathbf{m})\end{array}$ & $\begin{array}{l}\mathrm{NO}_{2} \\
\text { (m) }\end{array}$ & $\begin{array}{l}\mathrm{NO}_{3} \\
(\mathrm{~m})\end{array}$ & $\begin{array}{l}\mathbf{O H} \\
(\mathbf{m})\end{array}$ & $\begin{array}{l}\mathrm{PO}_{4} \\
\text { (m) }\end{array}$ & $\begin{array}{l}\mathrm{SO}_{4} \\
\text { (m) }\end{array}$ & $\begin{array}{l}\mathbf{F e} \\
(\mathbf{m})\end{array}$ & $\begin{array}{c}\mathbf{K} \\
(\mathbf{m})\end{array}$ & $\begin{array}{c}\mathbf{S i} \\
(\mathbf{m})\end{array}$ & $\begin{array}{c}\mathrm{U} \\
(\mathbf{m})\end{array}$ & $\begin{array}{l}\mathrm{Na} \\
\text { Calc } \\
(\mathbf{m})\end{array}$ & $\begin{array}{c}\mathrm{NO}_{2+}+ \\
\mathrm{NO}_{3} \\
(\mathrm{~m}) \\
\end{array}$ \\
\hline \multicolumn{18}{|c|}{ Dip Samples (Tank surface) } \\
\hline $2 / 15 / 01$ & 2000138614 & dip & $9.26 \mathrm{E}-01$ & $1.34 \mathrm{E}-02$ & $4.36 \mathrm{E}-02$ & $6.58 \mathrm{E}-03$ & $2.23 \mathrm{E}+00$ & $2.14 \mathrm{E}+00$ & $5.55 \mathrm{E}+00$ & $8.89 \mathrm{E}-03$ & $1.35 \mathrm{E}-02$ & $2.88 \mathrm{E}-04$ & $6.09 \mathrm{E}-02$ & $2.56 \mathrm{E}-03$ & $1.90 \mathrm{E}-05$ & $1.10 \mathrm{E}+01$ & $4.37 \mathrm{E}+00$ \\
\hline $12 / 5 / 00$ & 200125277 & dip & $1.11 \mathrm{E}+00$ & $1.63 \mathrm{E}-02$ & $2.05 \mathrm{E}-02$ & $5.26 \mathrm{E}-03$ & $2.43 \mathrm{E}+00$ & $3.69 \mathrm{E}+00$ & $6.35 \mathrm{E}+00$ & $1.15 \mathrm{E}-02$ & $2.49 \mathrm{E}-02$ & $3.09 \mathrm{E}-04$ & $6.92 \mathrm{E}-02$ & $2.48 \mathrm{E}-03$ & $2.50 \mathrm{E}-05$ & $1.36 \mathrm{E}+01$ & $6.12 \mathrm{E}+00$ \\
\hline 09/4/00 & surface dip ${ }^{*}$ & 250 & $1.04 \mathrm{E}+00$ & $1.55 \mathrm{E}-02$ & $3.41 \mathrm{E}-02$ & $5.32 \mathrm{E}-03$ & $1.91 \mathrm{E}+00$ & $4.53 \mathrm{E}+00$ & \begin{tabular}{|l|l|}
$6.43 \mathrm{E}+00$ \\
\end{tabular} & $1.06 \mathrm{E}-02$ & $2.00 \mathrm{E}-02$ & $1.90 \mathrm{E}-05$ & $6.81 \mathrm{E}-02$ & $9.75 \mathrm{E}-04$ & $2.40 \mathrm{E}-05$ & $1.40 \mathrm{E}+01$ & $6.43 \mathrm{E}+00$ \\
\hline \begin{tabular}{|l|}
$08 / 21 / 00$ \\
\end{tabular} & surface dip ${ }^{t}$ & 209 & 5.96E-01 & $1.33 \mathrm{E}-02$ & $2.91 \mathrm{E}-02$ & $4.56 \mathrm{E}-03$ & $9.45 \mathrm{E}-01$ & $1.58 \mathrm{E}+00$ & \begin{tabular}{|l|l}
$5.04 \mathrm{E}+00$ \\
\end{tabular} & $9.11 \mathrm{E}-03$ & $1.71 \mathrm{E}-02$ & 6.40E-04 & $5.83 \mathrm{E}-02$ & $7.55 \mathrm{E}-04$ & $2.10 \mathrm{E}-05$ & $8.23 \mathrm{E}+00$ & $2.52 \mathrm{E}+00$ \\
\hline $02 / 1 / 00$ & $\mathrm{TK} 32 \mathrm{H}-\mathrm{S} 1^{\mathrm{t}}$ & dip & 6.47E-01 & $1.36 \mathrm{E}-02$ & $2.97 \mathrm{E}-02$ & $4.66 \mathrm{E}-03$ & $1.21 \mathrm{E}+00$ & $1.87 \mathrm{E}+00$ & \begin{tabular}{|l|l}
$3.90 \mathrm{E}+00$ & \\
\end{tabular} & $9.31 \mathrm{E}-03$ & $1.75 \mathrm{E}-02$ & $2.09 \mathrm{E}-04$ & 5.96E-02 & $3.29 \mathrm{E}-04$ & $1.40 \mathrm{E}-05$ & $7.71 \mathrm{E}+00$ & $3.08 \mathrm{E}+00$ \\
\hline $02 / 1 / 00$ & $\mathrm{TK}^{2} 3 \mathrm{H}-\mathrm{S} 1^{\mathrm{t}}$ & dip & 6.67E-01 & $1.37 \mathrm{E}-02$ & $2.99 \mathrm{E}-02$ & $4.68 \mathrm{E}-03$ & $1.25 \mathrm{E}+00$ & $1.93 \mathrm{E}+00$ & \begin{tabular}{|l|l}
$4.02 \mathrm{E}+00$ & \\
\end{tabular} & $9.35 \mathrm{E}-03$ & $1.75 \mathrm{E}-02$ & $\mathrm{E}-04$ & \begin{tabular}{|l|l|}
$5.98 \mathrm{E}-02$ \\
\end{tabular} & $3.31 \mathrm{E}-04$ & $1.40 \mathrm{E}-05$ & $\mathrm{E}+00$ & $3.18 \mathrm{E}+00$ \\
\hline \multicolumn{18}{|c|}{ Variable Depth Samples 70-120" From Tank Bottom In Vicinity of Feed Pump (89" From Bottom) } \\
\hline 09/4/00 & $120^{\prime *}$ & 120 & $1.04 \mathrm{E}+00$ & $1.52 \mathrm{E}-02$ & $3.32 \mathrm{E}-02$ & $5.20 \mathrm{E}-03$ & $2.02 \mathrm{E}+00$ & $3.76 \mathrm{E}+00$ & $6.65 \mathrm{E}+00$ & $1.04 \mathrm{E}-02$ & $1.95 \mathrm{E}-02$ & 7.63E-04 & $6.65 \mathrm{E}-02$ & $1.08 \mathrm{E}-03$ & $3.20 \mathrm{E}-05$ & $1.36 \mathrm{E}+01$ & $5.78 \mathrm{E}+00$ \\
\hline 09/4/00 & $90^{\prime *}$ & 90 & \begin{tabular}{l|l|}
$4.39 \mathrm{E}-01$ \\
\end{tabular} & $1.46 \mathrm{E}-02$ & $3.20 \mathrm{E}-02$ & $5.02 \mathrm{E}-03$ & $1.54 \mathrm{E}+00$ & $4.05 \mathrm{E}+00$ & \begin{tabular}{|l|l|}
$5.21 \mathrm{E}+00$ \\
\end{tabular} & $1.00 \mathrm{E}-02$ & $1.88 \mathrm{E}-02$ & \begin{tabular}{ll|}
$4.44 \mathrm{E}-04$ \\
\end{tabular} & $6.42 \mathrm{E}-02$ & \begin{tabular}{|l|}
$8.61 \mathrm{E}-04$ \\
\end{tabular} & $1.21 \mathrm{E}-03$ & $1.13 \mathrm{E}+01$ & $5.59 \mathrm{E}+00$ \\
\hline $09 / 4 / 00$ & $70^{\prime *}$ & 70 & \begin{tabular}{l|l|}
$9.43 \mathrm{E}-01$ \\
\end{tabular} & $1.51 \mathrm{E}-02$ & $3.30 \mathrm{E}-02$ & $5.17 \mathrm{E}-03$ & $1.61 \mathrm{E}+00$ & $4.02 \mathrm{E}+00$ & \begin{tabular}{|l|l|}
$5.43 \mathrm{E}+00$ \\
\end{tabular} & $1.03 \mathrm{E}-02$ & $1.94 \mathrm{E}-02$ & \begin{tabular}{|l|l|}
$2.82 \mathrm{E}-03$ \\
\end{tabular} & $6.62 \mathrm{E}-02$ & \begin{tabular}{|l|l|}
$9.50 \mathrm{E}-04$ \\
\end{tabular} & $3.60 \mathrm{E}-05$ & $1.21 \mathrm{E}+01$ & $5.63 \mathrm{E}+00$ \\
\hline \begin{tabular}{|l|}
$08 / 21 / 00$ \\
\end{tabular} & $120^{\prime \prime}$ & 120 & \begin{tabular}{ll|}
$7.21 \mathrm{E}-01$ \\
\end{tabular} & $1.37 \mathrm{E}-02$ & $2.99 \mathrm{E}-02$ & $4.69 \mathrm{E}-03$ & $1.10 \mathrm{E}+00$ & $2.02 \mathrm{E}+00$ & \begin{tabular}{|l|l}
$6.07 \mathrm{E}+00$ & \\
\end{tabular} & $9.38 \mathrm{E}-03$ & $1.76 \mathrm{E}-02$ & 5.82E-04 & $6.00 \mathrm{E}-02$ & \begin{tabular}{|l|}
$6.99 \mathrm{E}-04$ \\
\end{tabular} & $1.70 \mathrm{E}-05$ & $9.99 \mathrm{E}+00$ & $3.13 \mathrm{E}+00$ \\
\hline \begin{tabular}{|l|}
$08 / 21 / 00$ \\
\end{tabular} & $90^{\prime \prime t}$ & 90 & 7.41E-01 & $1.38 \mathrm{E}-02$ & $3.02 \mathrm{E}-02$ & $4.73 \mathrm{E}-03$ & $1.25 \mathrm{E}+00$ & $2.14 \mathrm{E}+00$ & \begin{tabular}{|l|l}
$5.88 \mathrm{E}+00$ \\
\end{tabular} & 9.47E- 03 & $1.78 \mathrm{E}-02$ & 3.75E-04 & $6.06 \mathrm{E}-02$ & $8.08 \mathrm{E}-04$ & $1.14 \mathrm{E}-03$ & $1.01 \mathrm{E}+01$ & $3.39 \mathrm{E}-$ \\
\hline \begin{tabular}{|l|}
$08 / 21 / 00$ \\
\end{tabular} & $70^{\prime \prime t}$ & 70 & 7.26E-01 & $1.37 \mathrm{E}-02$ & $3.00 \mathrm{E}-02$ & $4.69 \mathrm{E}-03$ & $1.11 \mathrm{E}+00$ & $2.04 \mathrm{E}+00$ & \begin{tabular}{|l|l}
$6.11 \mathrm{E}+00$ \\
\end{tabular} & $9.39 \mathrm{E}-03$ & $1.76 \mathrm{E}-02$ & $4.84 \mathrm{E}-04$ & $6.01 \mathrm{E}-02$ & $7.22 \mathrm{E}-04$ & $1.80 \mathrm{E}-05$ & $1.01 \mathrm{E}+01$ & $3.15 \mathrm{E}+00$ \\
\hline $02 / 1 / 00$ & $\mathrm{TK}^{2} 2 \mathrm{H}-\mathrm{S} 1^{* *}$ & 89 & 6.62E-01 & $1.38 \mathrm{E}-02$ & $3.02 \mathrm{E}-02$ & $4.73 \mathrm{E}-03$ & $1.08 \mathrm{E}+00$ & $2.35 \mathrm{E}+00$ & $4.33 \mathrm{E}+00$ & $9.46 \mathrm{E}-03$ & $1.77 \mathrm{E}-02$ & 2.95E-04 & $6.05 \mathrm{E}-02$ & $1.16 \mathrm{E}-03$ & $1.90 \mathrm{E}-05$ & $8.49 \mathrm{E}+00$ & $3.42 \mathrm{E}+00$ \\
\hline $02 / 1 / 00$ & TK32H-S1 & 89 & 6.02E-01 & $1.36 \mathrm{E}-02$ & $2.98 \mathrm{E}-02$ & $4.67 \mathrm{E}-03$ & $1.00 \mathrm{E}+00$ & $2.18 \mathrm{E}+00$ & $4.03 \mathrm{E}+00$ & $9.35 \mathrm{E}-03$ & $1.75 \mathrm{E}-02$ & $3.85 \mathrm{E}-04$ & $5.98 \mathrm{E}-02$ & $1.05 \mathrm{E}-03$ & $1.80 \mathrm{E}-05$ & $7.89 \mathrm{E}+00$ & $3.18 \mathrm{E}+00$ \\
\hline \multicolumn{18}{|c|}{ Historic Samples } \\
\hline $11 / 24 / 92$ & 199674 & dip & 4.93E-01 [ & -03 & |2.16E-02 & |1.23E-02 & +00 & +00 & $|2.40 \mathrm{E}+00|$ & - -03 & 7.46E-02 & E-06 & 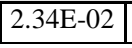 & $2.60 \mathrm{E}-05$ & $\mathrm{E}-05$ & $8+00$ & $5.11 \mathrm{E}+00$ \\
\hline
\end{tabular}


WSRC-TR-2001-00155, Rev. 1

Table VI. Tank 30 Modeling Data for SRS 3H Evaporator Drop Tank

\begin{tabular}{|c|c|c|c|c|c|c|c|c|c|c|c|c|c|c|c|c|c|}
\hline Date & $\begin{array}{l}\text { Description/ } \\
\text { Reference }\end{array}$ & $\begin{array}{l}\text { Height } \\
\text { (inchs) }\end{array}$ & $\begin{array}{c}\text { Al } \\
(\mathbf{m})\end{array}$ & $\begin{array}{c}\mathbf{C l} \\
(\mathbf{m})\end{array}$ & $\begin{array}{l}\mathrm{CO}_{3} \\
(\mathrm{~m})\end{array}$ & $\begin{array}{c}\mathbf{F} \\
(\mathbf{m})\end{array}$ & $\begin{array}{l}\mathrm{NO}_{2} \\
(\mathrm{~m})\end{array}$ & $\begin{array}{c}\mathrm{NO}_{3} \\
(\mathrm{~m})\end{array}$ & $\begin{array}{l}\mathrm{OH} \\
(\mathrm{m})\end{array}$ & $\begin{array}{l}\mathbf{P O}_{4} \\
(\mathrm{~m})\end{array}$ & $\begin{array}{l}\mathrm{SO}_{4} \\
(\mathrm{~m})\end{array}$ & $\begin{array}{l}\text { Fe } \\
(\mathbf{m})\end{array}$ & $\begin{array}{c}\mathbf{K} \\
(\mathbf{m})\end{array}$ & $\begin{array}{c}\mathbf{S i} \\
(\mathbf{m})\end{array}$ & $\begin{array}{c}\mathrm{U} \\
(\mathbf{m})\end{array}$ & $\begin{array}{l}\mathrm{Na} \\
\text { Calc } \\
(\mathbf{m})\end{array}$ & $\begin{array}{c}\mathrm{NO}_{2}+ \\
\mathrm{NO}_{3} \\
(\mathrm{~m}) \\
\end{array}$ \\
\hline \multicolumn{18}{|c|}{ Recent Samples } \\
\hline $12 / 1 / 00$ & 200125276 & $\operatorname{dip}$ & $9.76 \mathrm{E}-01$ & $1.97 \mathrm{E}-02$ & $1.41 \mathrm{E}-02$ & $3.50 \mathrm{E}-03$ & $2.76 \mathrm{E}+00$ & $4.00 \mathrm{E}+00$ & $5.86 \mathrm{E}+00$ & $1.20 \mathrm{E}-02$ & $2.10 \mathrm{E}-02$ & 7.37E-04 & $8.05 \mathrm{E}-02$ & $3.70 \mathrm{E}-03$ & $4.10 \mathrm{E}-05$ & $1.36 \mathrm{E}+01$ & $6.76 \mathrm{E}+00$ \\
\hline $12 / 01 / 00$ & $\begin{array}{c}\text { 1of } 3 \\
\text { nonroutine }\end{array}$ & 240 & $1.03 \mathrm{E}+00$ & $1.90 \mathrm{E}-02$ & $1.37 \mathrm{E}-02$ & $3.38 \mathrm{E}-03$ & $1.70 \mathrm{E}+00$ & $3.61 \mathrm{E}+00$ & $6.36 \mathrm{E}+00$ & $1.16 \mathrm{E}-02$ & $2.03 \mathrm{E}-02$ & $6.22 \mathrm{E}-03$ & $7.78 \mathrm{E}-02$ & $4.38 \mathrm{E}-04$ & $8.40 \mathrm{E}-05$ & $1.27 \mathrm{E}+01$ & $5.30 \mathrm{E}+00$ \\
\hline $12 / 01 / 00$ & $\begin{array}{c}2 \text { of } 3 \\
\text { nonroutine }\end{array}$ & 200 & $1.01 \mathrm{E}+00$ & $1.90 \mathrm{E}-02$ & $1.37 \mathrm{E}-02$ & $3.38 \mathrm{E}-03$ & $1.73 \mathrm{E}+00$ & $3.64 \mathrm{E}+00$ & $6.33 \mathrm{E}+00$ & $1.16 \mathrm{E}-02$ & $2.03 \mathrm{E}-02$ & 4.69E-04 & $7.79 \mathrm{E}-02$ & $4.27 \mathrm{E}-04$ & $5.50 \mathrm{E}-05$ & $1.28 \mathrm{E}+01$ & $5.37 \mathrm{E}+00$ \\
\hline $12 / 01 / 00$ & $\begin{array}{c}3 \text { of } 3 \\
\text { nonroutine } \\
\text { (surface) }\end{array}$ & 170 & $1.01 \mathrm{E}+00$ & $1.90 \mathrm{E}-02$ & $1.36 \mathrm{E}-02$ & $3.38 \mathrm{E}-03$ & $1.79 \mathrm{E}+00$ & $3.57 \mathrm{E}+00$ & $6.43 \mathrm{E}+00$ & $1.16 \mathrm{E}-02$ & $2.03 \mathrm{E}-02$ & 7.12E-04 & $7.78 \mathrm{E}-02$ & $5.63 \mathrm{E}-04$ & $2.50 \mathrm{E}-05$ & $1.28 \mathrm{E}+01$ & $5.36 \mathrm{E}+00$ \\
\hline $08 / 21 / 00$ & Tk30H-S2 & 179 & $1.02 \mathrm{E}+00$ & $1.92 \mathrm{E}-02$ & $1.38 \mathrm{E}-02$ & $3.41 \mathrm{E}-03$ & $1.79 \mathrm{E}+00$ & $3.79 \mathrm{E}+00$ & $6.64 \mathrm{E}+00$ & $1.17 \mathrm{E}-02$ & $2.04 \mathrm{E}-02$ & $4.70 \mathrm{E}-04$ & 7.84E-02 & $1.07 \mathrm{E}-03$ & $5.60 \mathrm{E}-05$ & $1.33 \mathrm{E}+01$ & $5.58 \mathrm{E}+00$ \\
\hline $08 / 21 / 00$ & Tk30H-S1 & 348 & $1.02 \mathrm{E}+00$ & $1.92 \mathrm{E}-02$ & $1.38 \mathrm{E}-02$ & $3.41 \mathrm{E}-03$ & $2.14 \mathrm{E}+00$ & $3.59 \mathrm{E}+00$ & $5.84 \mathrm{E}+00$ & $1.17 \mathrm{E}-02$ & $2.05 \mathrm{E}-02$ & $7.14 \mathrm{E}-04$ & $7.85 \mathrm{E}-02$ & $4.74 \mathrm{E}-04$ & $2.30 \mathrm{E}-05$ & $1.26 \mathrm{E}+01$ & $5.73 \mathrm{E}+00$ \\
\hline $02 / 01 / 00$ & Tk30H-VDS & unknown & $8.02 \mathrm{E}-01$ & $1.86 \mathrm{E}-02$ & $1.34 \mathrm{E}-02$ & $3.32 \mathrm{E}-03$ & $1.64 \mathrm{E}+00$ & $3.48 \mathrm{E}+00$ & $6.09 \mathrm{E}+00$ & $1.14 \mathrm{E}-02$ & $1.99 \mathrm{E}-02$ & $1.08 \mathrm{E}-03$ & $7.63 \mathrm{E}-02$ & $8.02 \mathrm{E}-04$ & $2.80 \mathrm{E}-05$ & $1.21 \mathrm{E}+01$ & $5.12 \mathrm{E}+00$ \\
\hline \multicolumn{18}{|c|}{ Historic Samples } \\
\hline $11 / 24 / 92$ & 199672 & $\operatorname{dip}$ & $5.10 \mathrm{E}-01$ & $1.49 \mathrm{E}-02$ & $5.28 \mathrm{E}-01$ & $1.21 \mathrm{E}-02$ & $1.11 \mathrm{E}+00$ & $3.14 \mathrm{E}+00$ & $4.57 \mathrm{E}+00$ & $6.67 \mathrm{E}-03$ & \begin{tabular}{|l|}
$7.04 \mathrm{E}-02$ \\
\end{tabular} & $4.00 \mathrm{E}-06$ & $4.73 \mathrm{E}-02$ & $3.16 \mathrm{E}-03$ & $2.10 \mathrm{E}-05$ & $1.05 \mathrm{E}+01$ & $4.25 \mathrm{E}+00$ \\
\hline
\end{tabular}

$\mathrm{m}=$ molal $\left(\right.$ mole $\left./ \mathrm{Kg} \mathrm{H}_{2} \mathrm{O}\right)$ 
No modeling was performed on samples that were analyzed from the "Zone of Turbidity" so that the data interpretation would not be confounded with analytic sampling from regions not accessible to the Tank 32 feed pump. For example, Wilmarth extensively characterized two variable depth samples (VDS) taken from Tank 32 in February 2000. ${ }^{36}$ The height at which the two VDS samples were taken is unknown. The analyses in Wilmarth's report shows that these samples were enriched in $\mathrm{Fe}$ and $\mathrm{Mn}$ suggesting that they were taken close to the surface of the sludge. In addition, the VDS samples taken in August 2000 at a height of 54" from the bottom of the tank, only 6 inches above the sludge layer, was highly enriched in Fe (see Table III). ${ }^{37}$ This sample was also highly enriched in silica. The data from this sample was not used in modeling.

\subsubsection{Tank 30H (Drop Tank)}

There is a salt layer in Tank 30 at a depth of $\sim 8$ ". One incomplete analysis by Wilmarth of this sample was not used in the modeling. The remainder of the supernate was considered to be one chemical population. One sample analyzed in December 2000 by the F-area laboratory was not used in modeling due to analytic bias as discussed in Section 4.3 and shown in Table IV. The remaining data in Table IV are from the SRTC laboratory and span the period from February 2000 to December 2000.

\subsection{MODELING APPROACH}

The molar tank compositions given in Table III and Table IV were converted into molal units which are the units of preference in the GWB software. The conversion formula takes the form ${ }^{5}$

$$
\left[\mathrm{i}^{+/-}\right]_{\mathrm{m}}=\frac{\left[\mathrm{i}^{+/-}\right]_{\mathrm{M}}}{\rho-\sum \rho_{\text {solutes }}}
$$

where $\left[i^{+/-}\right]_{M}$ and $\left[i^{+/-}\right]_{m}$ are the molar and molal concentrations of ionic species $i$, respectively, $\rho$ is the solution density in $\mathrm{kg} / \mathrm{L}$, and $\Sigma \rho_{\text {solutes }}$ is the sum of the partial densities of the dissolved solids. The solution density is calculated using Equation 2. For each ionic species, the partial dissolved solids density is the product of its molarity and its ionic weight in $\mathrm{g} / \mathrm{mole}$. Ionic weights for the most prevalent species in basic solutions are used. These are $\mathrm{Al}(\mathrm{OH})_{4}{ }^{-}, \mathrm{Cl}^{-}, \mathrm{CO}_{3}{ }^{2-}, \mathrm{F}^{-}, \mathrm{NO}_{2}{ }^{-}, \mathrm{NO}_{3}{ }^{-}, \mathrm{OH}^{-}, \mathrm{PO}_{4}{ }^{3-}, \mathrm{SO}_{4}{ }^{2-}, \mathrm{Fe}(\mathrm{OH})_{4}{ }^{-}, \mathrm{K}^{+}$, $\mathrm{H}_{2} \mathrm{SiO}_{4}{ }^{2-},\left(\mathrm{UO}_{2}\right)_{3}(\mathrm{OH})_{7}{ }^{-}$, and $\mathrm{Na}^{+}$. Table $\mathrm{V}$ and Table VI reflect the input data in molalities used for modeling.

There is limited solubility data for amorphous $\mathrm{SiO}_{2}$ and $\mathrm{Al}(\mathrm{OH})_{3}$ in very basic high ionic strength solutions such as those in the SRS $3 \mathrm{H}$ Evaporator. This is discussed in more detail in Part I. ${ }^{3}$ Comparison with available $\mathrm{SiO}_{2}$ solubility data in the literature showed 
that the solubility data used in GWB appeared to adequately represent amorphous $\mathrm{SiO}_{2}$ equilibria in basic $\mathrm{pH}$. GWB has the mononuclear silicate species $\mathrm{H}_{4} \mathrm{SiO}_{4}$ called $\mathrm{SiO}_{2}(\mathrm{aq})$, $\mathrm{H}_{3} \mathrm{SiO}_{4}^{-}$and $\mathrm{H}_{2} \mathrm{SiO}_{4}^{2-}$ of which the $\mathrm{H}_{2} \mathrm{SiO}_{4}^{2-}$ species is the most prevalent at $\mathrm{pH}$ values $>13$. $^{43}$ GWB also contains the two most abundant ${ }^{44,43}$ polynuclear silicate species, the tetrameric $\mathrm{H}_{4}\left(\mathrm{H}_{2} \mathrm{SiO}_{4}\right)_{4}^{4-}$ and $\mathrm{H}_{6}\left(\mathrm{H}_{2} \mathrm{SiO}_{4}\right)_{4}{ }_{4}^{--}$of which the tetrameric $\mathrm{H}_{4}\left(\mathrm{H}_{2} \mathrm{SiO}_{4}\right)_{4}{ }^{4-}$ is the most prevalent species at $\mathrm{pH}$ values $>13 .{ }^{43}$ Polynuclear $\mathrm{Si}(\mathrm{IV})$ species are only significant at $\mathrm{pH}>10$ and a total dissolved Si concentrations larger than $10^{-3} \mathrm{M}^{45}$ In addition, the significance of the polynuclear $\mathrm{Si}(\mathrm{IV})$ species tends to decrease with increasing temperature. ${ }^{46}$ Since the SRS $3 \mathrm{H}$ Evaporator Si concentrations are in the $10^{-4} \mathrm{M}$ concentration range (Table III and Table IV) and the polynuclear Si(IV) species are of minimal importance at the elevated evaporator operating temperatures, the absence of the remaining polynuclear $\mathrm{Si}(\mathrm{IV})$ species in the GWB database is not considered to significantly impact the modeling.

Examination of the gibbsite solubility data in GWB with that in the literature indicated that Russell's ${ }^{47}$ solubility data at a sodium molality of 8.5 would be more appropriate for modeling at the high ionic strength of the SRS Evaporators. The Russel solubility data for gibbsite (alpha aluminum trihydrate) and diaspore (alpha aluminum monohydrate) was added to GWB database and designated as "gibbsite-M" and "diaspore-M" to distinguish these modified aluminum hydroxides from the gibbsite and diaspore solubility already in GWB. The Russel gibbsite-M and diaspore-M were used for modeling the SRS 3H Evaporator solutions. The data for the solubility of $\mathrm{NaAlO}_{2}$ and $\mathrm{AlO}_{2}^{-2}$ of Reynolds and Herting ${ }^{48}$ were also added to GWB for completeness. Detailed descriptions of the manner in which the data were added to the GWB database appear in Part I. ${ }^{3}$

The data of $\mathrm{Ejaz}^{22}$ for the solubility of the NAS gel and Zeolite-A was added to the GWB database as was the data of Gasteiger ${ }^{17}$ for an amorphous precipitate containing Zeolite-A and nitrited sodalite, hereafter referred to as "mixed zeolite." Ejaz measured solubilities by dissolving Zeolite-A and NAS gel precipitate in 3.02, 3.32, 3.89, and 4.39 molar $\mathrm{NaOH}$ solutions. Temperatures for the Ejaz measurements were $30^{\circ} \mathrm{C}, 50^{\circ} \mathrm{C}, 65^{\circ} \mathrm{C}$, and $80^{\circ} \mathrm{C}$. At the highest temperature and concentration, the NAS solubilities decreased significantly. Ejaz attributed this decrease to crystallization of zeolites from solution. Ejaz's data for the NAS gel and Zeolite-A were extrapolated to a sodium molarity of 8.5 appropriate to the SRS evaporator solutions. This extrapolation is discussed in greater detail in Part $\mathrm{I}^{3}$

Gasteiger measured mixed zeolite solubilities by observing rates of precipitation from "green liquor" solutions that were supersaturated with aluminates and silicates. ("Green liquor" is a term from the pulp and paper industry that describes solutions that dissolve wood pulp). Green liquor is a basic solution that contains sodium carbonates, sodium sulfides, and a small amount of sodium sulfates.) The Gasteiger measurements were restricted to one temperature, $95^{\circ} \mathrm{C}$, so it was not possible to determine an activation energy for the variation of solubility with temperature. In the absence of this information, the measured mixed zeolite solubility at $95^{\circ} \mathrm{C}$ was combined with the activation energy for the NAS gel. A comparison of activity diagrams for NAS gel and Gasteiger's mixed zeolite justifies the substitution of the NAS gel activation energy. This comparison showed that the NAS gel and the mixed zeolites had nearly identical aluminate and 


\section{WSRC-TR-2001-00155, Rev. 1}

silicate solubilities at $95^{\circ} \mathrm{C}$. This suggests that the mixed zeolites in Gasteiger's tests formed from an NAS gel precursor, which controlled the measured solubilities.

The mixed zeolite data was extrapolated to a sodium molarity of 8.5 appropriate to the SRS evaporator solutions. The extrapolation is discussed in greater detail in Part I. ${ }^{3}$

Similarly, Park and Englezos ${ }^{49}$ measured the solubility of hydroxysodalite by observing rates of recipitation from "green liquor" and "white liquor" solutions that were supersaturated with aluminates and silicates. ("White liquor" is another term from the pulp and paper industry that describes solutions that dissolve wood pulp). Park and Englezos specifically studied the effects of $\left[\mathrm{OH}^{-}\right],\left[\mathrm{CO}_{3}^{2-}\right],\left[\mathrm{SO}_{4}^{2-}\right]$ and $\mathrm{Na}_{2} \mathrm{~S}$ on the precipitation of aluminosilicates in highly alkaline solutions. Their solubility measurements were ranged from 2.0 to 3.0 molal $\mathrm{NaOH}$. The hydroxysodalite data was extrapolated to a sodium molarity of 8.5 appropriate to the SRS evaporator solutions. The extrapolation is discussed in greater detail in Part I. ${ }^{3}$

The appearance/precipitation of the NAS gel is the kinetically most rapid step in the sequential formation of NAS gel $\rightarrow$ Zeolite-A $\rightarrow$ sodalite $\rightarrow$ cancrinite. The NAS gel is the least dense and most soluble phase. The density and stoichiometry of the different phases causes them to have different relative solubilities and different boundary positions on an activity diagram (Figure 6). Since the operating strategy for the SRS evaporators is to avoid any potential to form nitrated sodalite/cancrinite or any of the precursor phases, modeling of the NAS phase boundary in the activity diagrams is logical, e.g. the sodalite/cancrinite cannot form unless the precursor gel forms (see discussion in Section 2.3). Modeling the evaporator chemistry in terms of supersaturation with respect to the NAS gel phase is also appropriate because the individual phase transformations from NAS gel $\rightarrow$ Zeolite- $\mathrm{A} \rightarrow$ sodalite $\rightarrow$ cancrinite are not reversible. 
WSRC-TR-2001-00155, Rev. 1

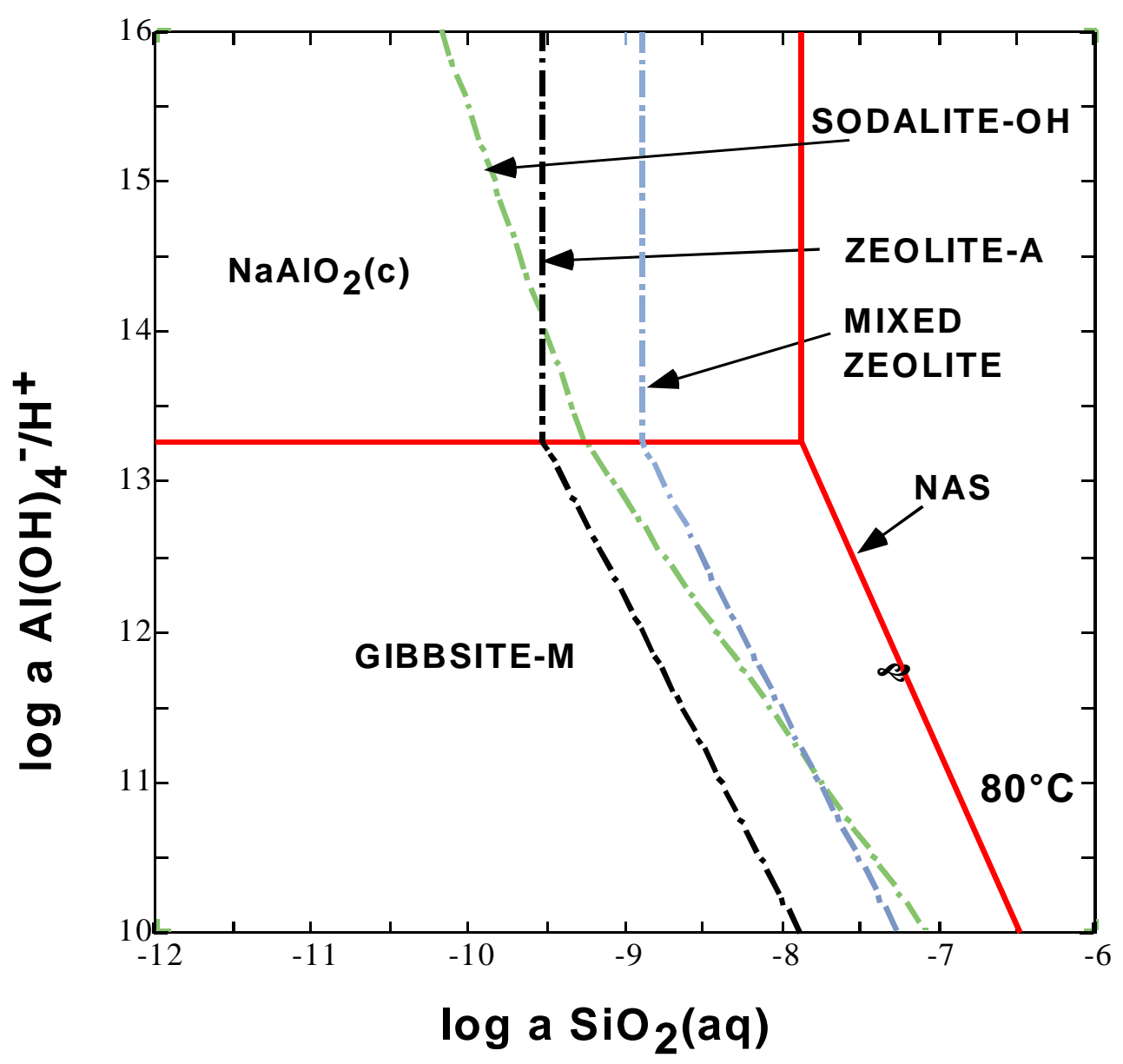

Figure 6. Relative Stability Boundaries of NAS gel, "mixed zeolite," Zeolite-A and hydroxysodalite.

The first step in preparing activity diagrams is to enter the average molal concentration of the ionic species for each set of measured tank chemistries in a given depth population into the GWB REACT subroutine. Equilibrium with air is specified by specifying the oxygen fugacity of air as input. This allows the oxidation states of iron, uranium, nitrate, etc to be speciated for solutions in equilibrium with air in the calculations. REACT outputs the pertinent activities of all ionic species. To account for mineral equilibrium under supersaturated conditions, no minerals are allowed to precipitate during the REACT calculation. The activities calculated in REACT from the solution concentrations are then used in the ACT2 subroutine to calculate the activity diagrams. This ensures that individual data points from each population are plotted on the activity diagram calculated from their pooled average chemistry. The approach is discussed in detail in Part I. ${ }^{3}$ 


\subsection{ACTIVITY DIAGRAMS FOR THE SRS 3H EVAPORATOR}

Activity diagrams were generated at $25^{\circ} \mathrm{C}$, which represents the temperature at which the tank solutions were analyzed. In order to evaluate the solution equilibria at the elevated temperature $\left(40^{\circ} \mathrm{C}\right)$ of the feed and drop tanks, the solution temperature was incrementally increased, using the polythermal reaction option in GWB. Separate calculations were performed to generate activity diagrams at the estimated evaporator temperature of $140^{\circ} \mathrm{C}$. These calculations simulated evaporation by a stepwise removal of $40 \%$ of the water from the solution. This amount of evaporation changes the solution density from about $1.4 \mathrm{~g} / \mathrm{cm}^{3}$ to about $1.6 \mathrm{~g} / \mathrm{cm}^{3}$, the latter number being the operational target density for the $3 \mathrm{H}$ Evaporator.

\subsection{Activity Diagrams at the Solution Measurement Temperature}

Activity diagrams were generated at $25^{\circ} \mathrm{C}$ which represents the equilibrium at the temperature at which the tank solutions were analyzed. At ambient temperature the NAS gel phase and gibbsite, $\mathrm{Al}(\mathrm{OH})_{3}$, and $\mathrm{NaAlO}_{2} \bullet 1.25 \mathrm{H}_{2} \mathrm{O}$ are the stable solid phases. Note that $\mathrm{Al}(\mathrm{OH})_{3}$ is not found to precipitate in the evaporator as the evaporator residence times are too short compared to the kinetic formation time of gibbsite. However, the NAS gel is in equilibrium with $\mathrm{Al}(\mathrm{OH})_{3}$ in solution and/or amorphous $\mathrm{Al}(\mathrm{OH})_{3}$. The $\mathrm{NaAlO}_{2} \bullet 1.25 \mathrm{H}_{2} \mathrm{O}$ phase is found in the SRS salt deposits, otherwise, the $\mathrm{NaAlO}_{2}$ is part of the dissolved solids in the tank solutions. At the elevated temperatures in the evaporator, denser aluminate phases such as diaspore $(\mathrm{AlOOH})$ are stable rather than gibbsite and a mixed zeolite phase (partially crystallized with respect to sodalite/cancrinite) will likely be more stable than the NAS gel. The kinetics of diaspore formation in the evaporator are also kinetically slow and it is precluded from precipitating during the short evaporator residence times.

The silica data from Wilmarth's various studies ${ }^{36,37,38}$ was used preferentially to the FArea silica data in the modeling of the SRS 3H Evaporator. Figure 7 demonstrates how the usage of biased silicon analyses can impact evaporator modeling, e.g. the data from FArea laboratory would indicate that the SRS 2H Evaporator samples are closer to the NAS boundary than the SRTC data although both sets of data indicate that the solutions are in steady state equilibrium with $\mathrm{Al}(\mathrm{OH})_{3}$. The data plotted in Figure 7 is the surface dip sample population in the Tank 32 feed tank. The F-area laboratory data is in the 53-59 ppm Si range (Table II) while the SRTC data is in the 20 ppm Si range (Table II). The source of this bias is discussed in Section 4.3.

The solubility data of Russell ${ }^{47}$ for $\mathrm{Al}(\mathrm{OH})_{3}$ was used in the modeling of the SRS $3 \mathrm{H}$ Evaporator rather than the $\mathrm{Al}(\mathrm{OH})_{3}$ data in $\mathrm{GWB}$. The position of the stability field boundary between gibbsite and NAS changes very little when the solubility data in GWB is used (see dashed lines in Figure 8a) instead of the Russell ${ }^{47}$ data which was obtained from solutions at 8.5 molal $\mathrm{Na}$ at $25^{\circ} \mathrm{C}$. However, at $140^{\circ} \mathrm{C}$, the position of the stability field boundary between $\mathrm{AlOOH}$ (diaspore) and NAS changes by about an order of 


\section{WSRC-TR-2001-00155, Rev. 1}

magnitude when the solubility data in GWB is used (see dashed lines in Figure 8b) instead of the Russell ${ }^{47}$ data at 8.5 molal Na.

Activity diagrams were generated using Wilmarth's data for Tank 32 dip and variable depth samples before and after recycle from Tank 30. Figure 9 shows the Tank 32 dip samples before (black circles) and after (green stars) recycle. There is not much difference in the analytic results before and after recycle and the solutions are in steady state equilibrium with gibbsite at ambient conditions. The equations governing the equilibrium between the phases shown in Figure 9 and the remaining figures are:

between gibbsite and $\mathrm{NaAlO}_{2}$

$$
\operatorname{Gibbsite}(w)+\frac{\mathrm{Al}(\mathrm{OH})_{4}^{-}}{\mathrm{H}^{+}}+2 \mathrm{Na}^{+} \Leftrightarrow 2 \mathrm{NaAlO}_{2}(\mathrm{c})+3 \mathrm{H}_{2} \mathrm{O}
$$

between gibbsite and $\mathrm{UO}_{2}\left(\mathrm{H}_{2} \mathrm{PO}_{4}\right)_{2}$

$$
6 \mathrm{UO}_{2}\left(\mathrm{H}_{2} \mathrm{PO}_{4}\right)_{2}+19 \frac{\mathrm{Al}(\mathrm{OH})_{4}^{-}}{\mathrm{H}^{+}} \Leftrightarrow 19 \operatorname{Gibbsite}(\mathrm{w})+5 \mathrm{H}_{2} \mathrm{O}+2\left(\mathrm{UO}_{2}\right)_{3}(\mathrm{OH})_{7}^{-}+12 \mathrm{PO}_{4}^{3-}
$$

between gibbsite and NAS is

$$
6 \operatorname{Gibbsite}(\mathrm{w})+13 \mathrm{H}_{2} \mathrm{O}+6 \frac{\mathrm{Al}(\mathrm{OH})_{4}^{-}}{\mathrm{H}^{+}}+14 \mathrm{SiO}_{2}(\mathrm{aq})+12 \mathrm{Na}^{+} \Leftrightarrow \mathrm{NAS}
$$

between $\mathrm{NaAlO}_{2}$ and NAS is

$$
12 \mathrm{NaAlO}_{2}(\mathrm{c})+31 \mathrm{H}_{2} \mathrm{O}+14 \mathrm{SiO}_{2}(\mathrm{aq}) \Leftrightarrow \mathrm{NAS}
$$

between $\mathrm{UO}_{2}\left(\mathrm{H}_{2} \mathrm{PO}_{4}\right)_{2}$ and NAS is

$$
\begin{aligned}
& 36 \mathrm{UO}_{2}\left(\mathrm{H}_{2} \mathrm{PO}_{4}\right)_{2}+217 \mathrm{H}_{2} \mathrm{O}+228 \frac{\mathrm{Al}(\mathrm{OH})_{4}^{-}}{\mathrm{H}^{+}}+266 \mathrm{SiO}_{2}(\mathrm{aq})+228 \mathrm{Na}^{+} \Leftrightarrow \\
& 19 \mathrm{NAS}+12\left(\mathrm{UO}_{2}\right)_{3}(\mathrm{OH})_{7}^{-}+72 \mathrm{PO}_{4}^{3-}
\end{aligned}
$$


Figure 10 shows the variable depth sample compositions before (black circles) and after (green stars) recycle from Tank 30. An additional set of variable depth samples (VDS) taken in February 2000 is shown by the orange triangles. The February 2000 samples were taken within two hours of the transfer from Tank 30 to the feed tank (Tank 32). This figure indicates that the samples taken within two hours of the transfer appear slightly elevated in silica concentration compared to the other VDS samples but not to the point that it drives the solution equilibrium into the stability field of the NAS gel. All of the samples are saturated with respect to gibbsite.

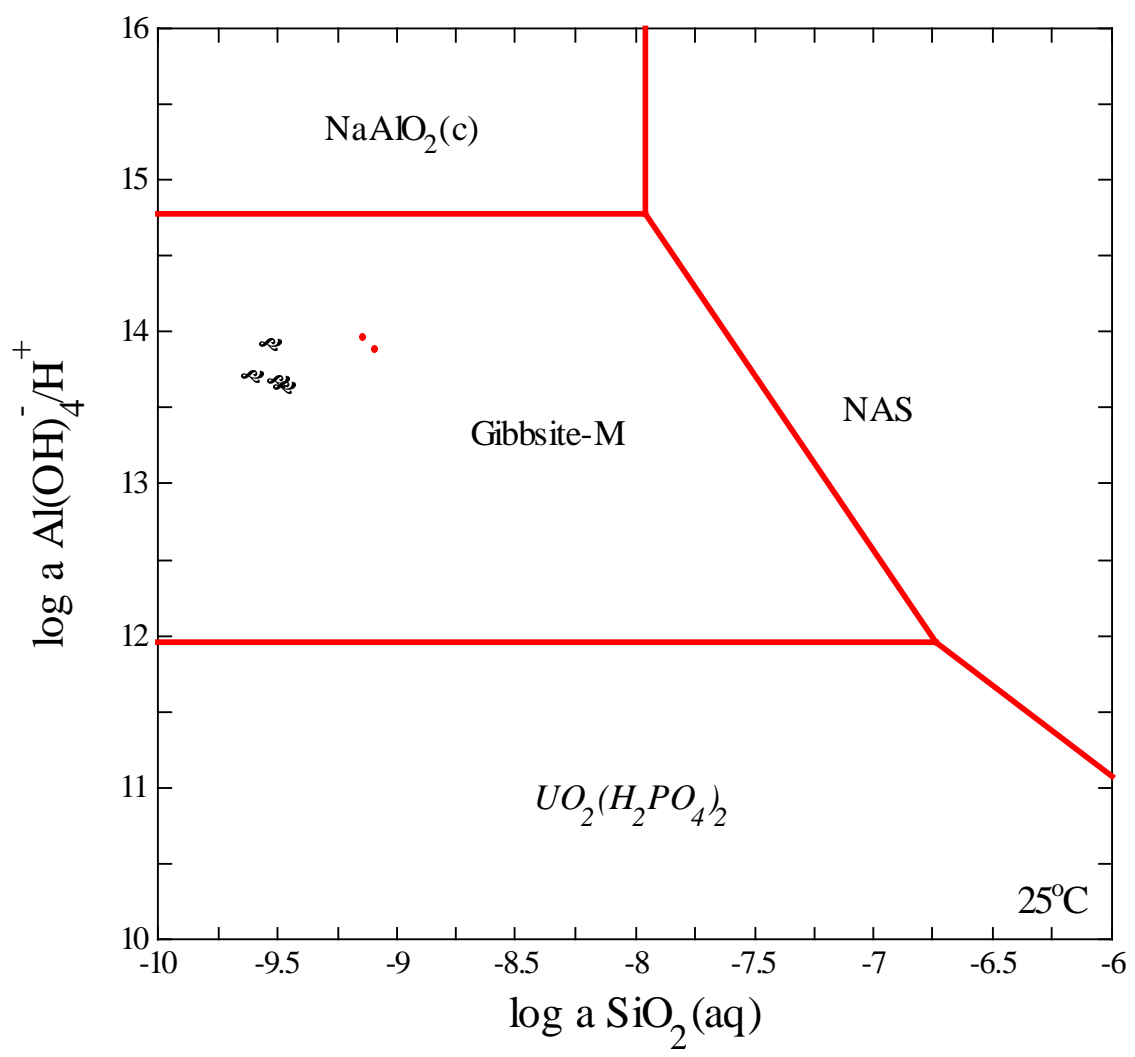

Figure 7. Activity diagram for Tank 32 dip samples at $25^{\circ} \mathrm{C}$. The black circles are solution data generated by SRTC. The red diamonds indicate the comparable position of data from the F-area laboratory which is shown to be biased high in silica. The Si concentrations from F-area laboratory are in the range of 53$59 \mathrm{ppm}$ Si range (Table II) while the SRTC data is in the $20 \mathrm{ppm}$ Si range (Table II). 
WSRC-TR-2001-00155, Rev. 1
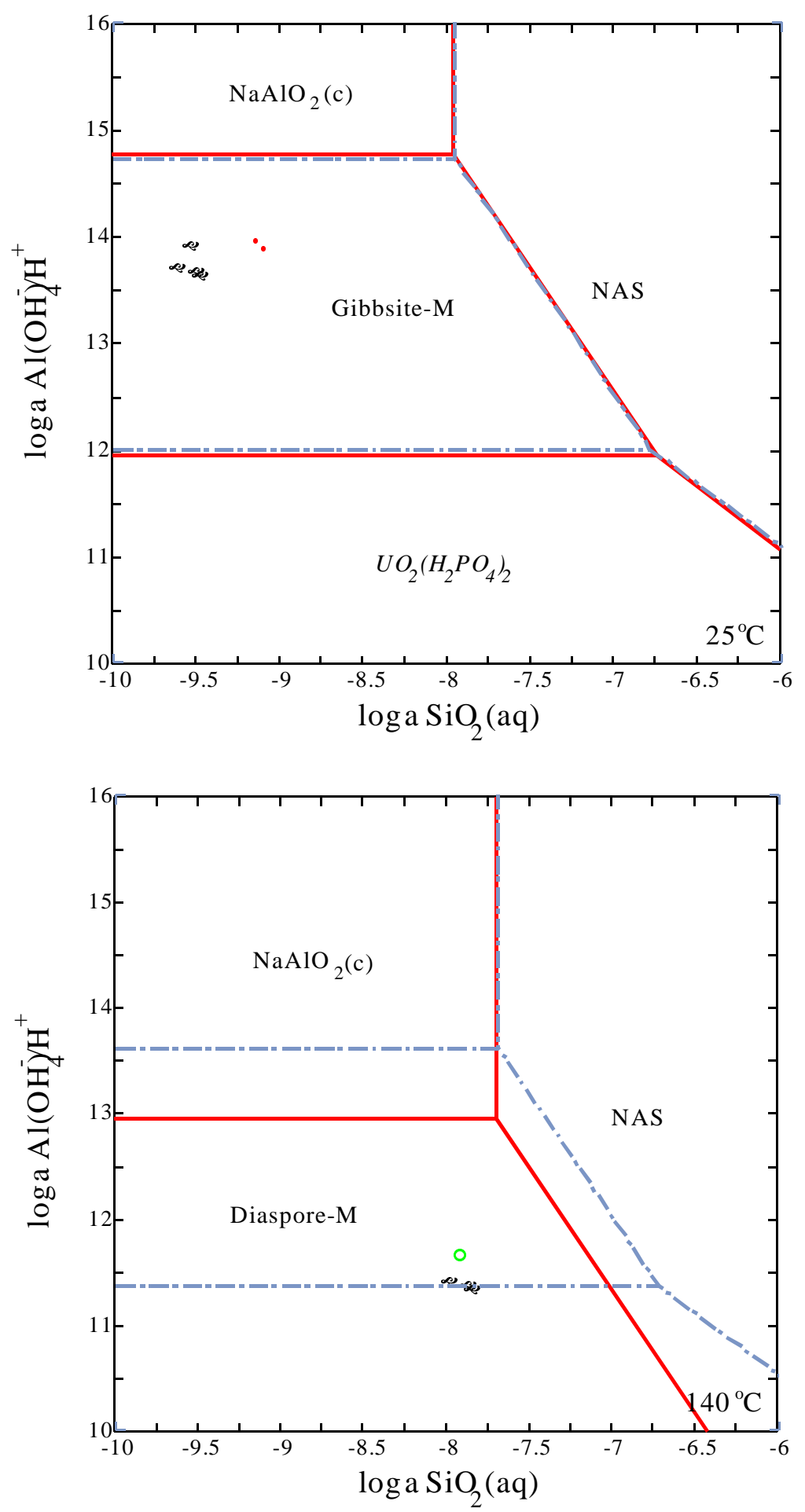

Figure 8. Activity diagrams for Tank 32 dip samples at $25^{\circ} \mathrm{C}$ and $140^{\circ} \mathrm{C}$. The dashed lines show how the stability diagrams change when the $\mathrm{Al}(\mathrm{OH})_{3}$ and $\mathrm{AlOOH}$ solubility in GWB is substituted for the $8.5 \mathrm{M}$ Russell ${ }^{47}$ data for these species. 
WSRC-TR-2001-00155, Rev. 1

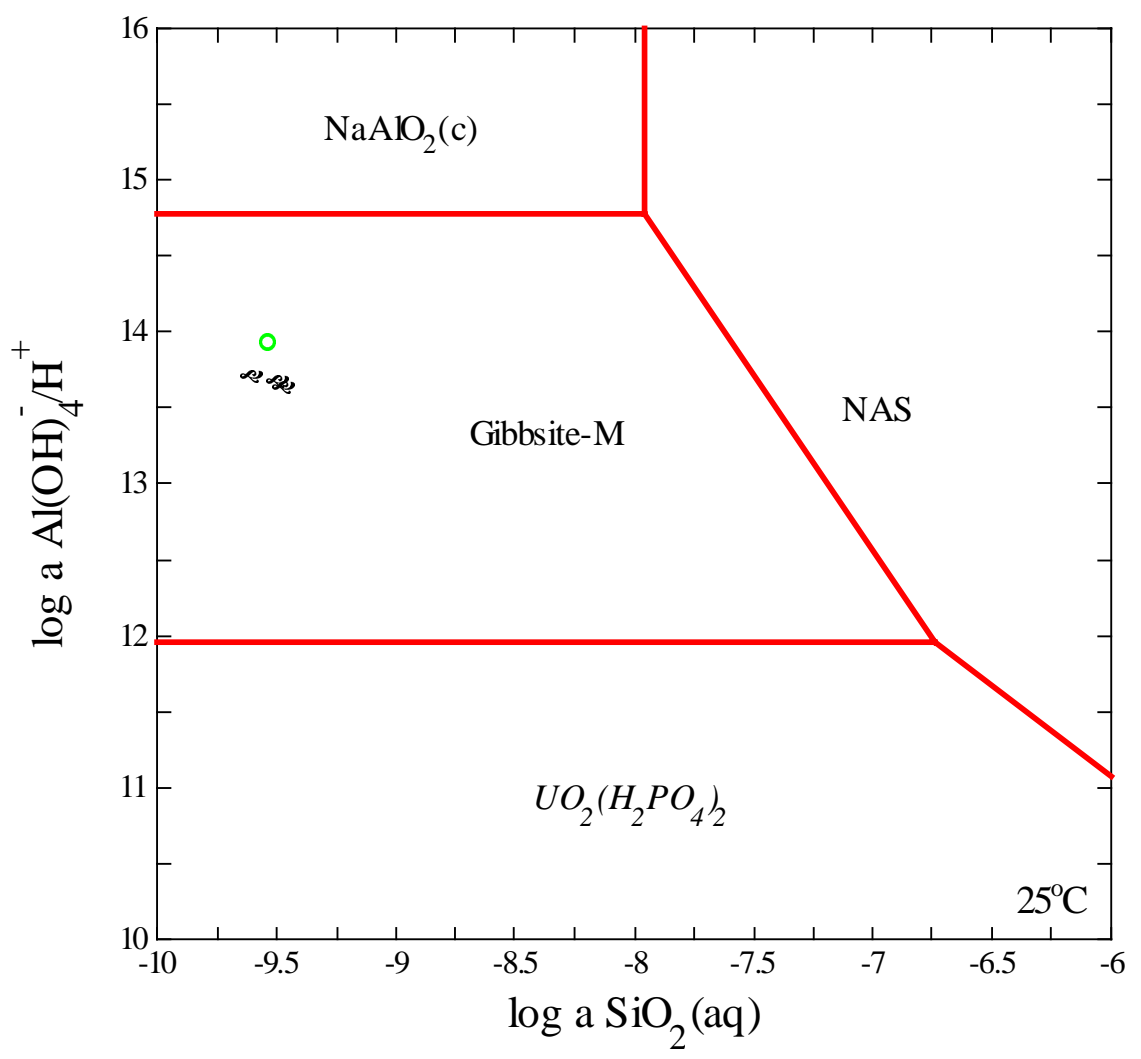

Figure 9 Activity diagram for Tank 32 dip samples at $25^{\circ} \mathrm{C}$ before and after recycle from Tank 30 . The black circles are solution data before recycle and the green star is the solution data after recycle. 
WSRC-TR-2001-00155, Rev. 1

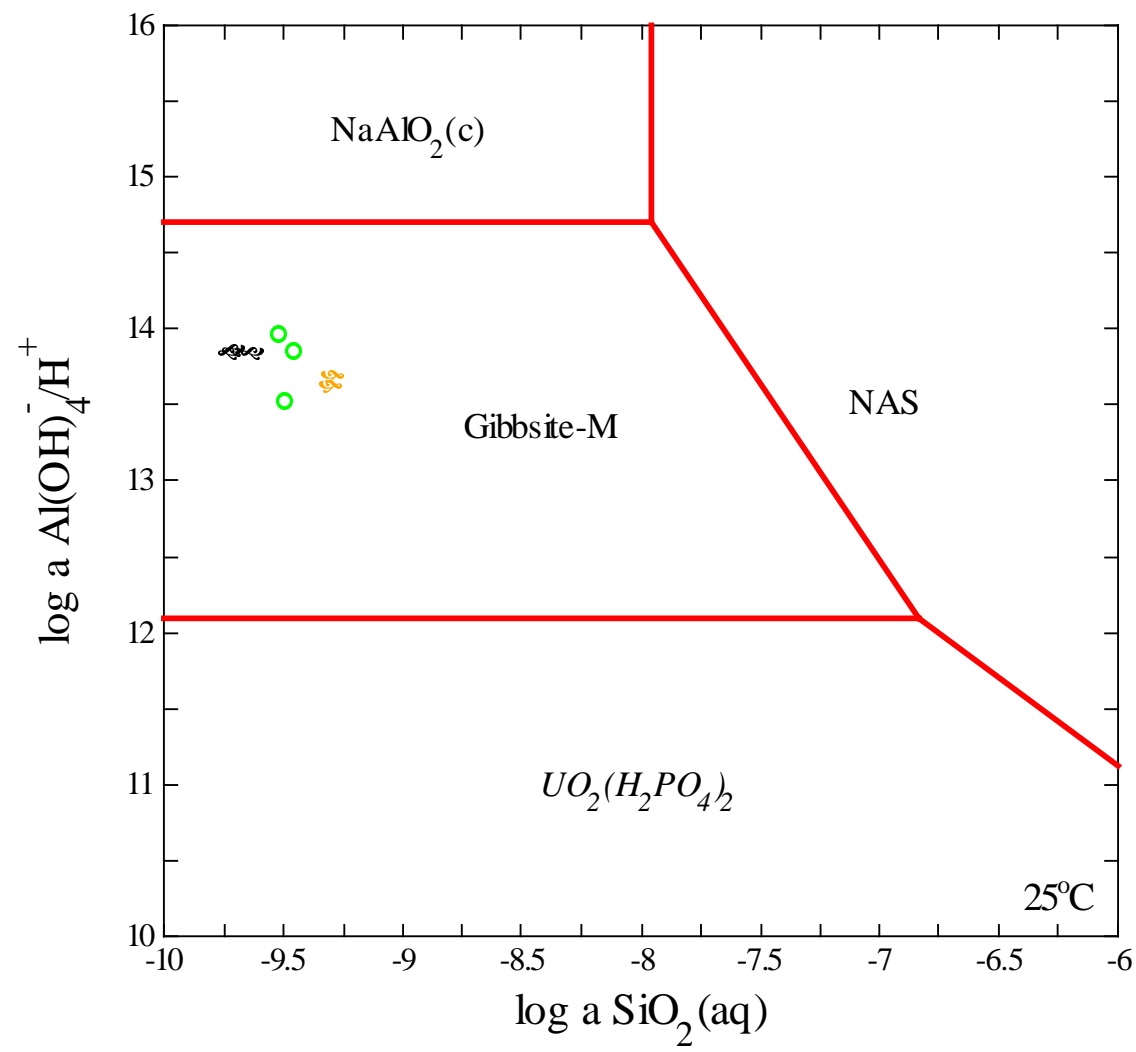

Figure 10. Activity diagram for Tank 32 variable depth samples at $25^{\circ} \mathrm{C}$ before and after recycle from Tank 30 . The black circles are solution data before recycle. The green stars are the solution data after recycle from Tank 30. The orange triangles are the samples from February 2000 that were taken at the height of the feed pump only a few hours after recycle from Tank 30 to Tank 32.

For completeness, the activity diagram for Tank 30 at $25^{\circ} \mathrm{C}$ (Figure 11) was generated. Figure 11 indicates that the solutions in Tank 30 are not in the stability field of the NAS gel but are saturated with respect to gibbsite. The average composition of the solutions from Tank 30 (from Table II) that were used to generate the activity diagram boundaries. 
WSRC-TR-2001-00155, Rev. 1

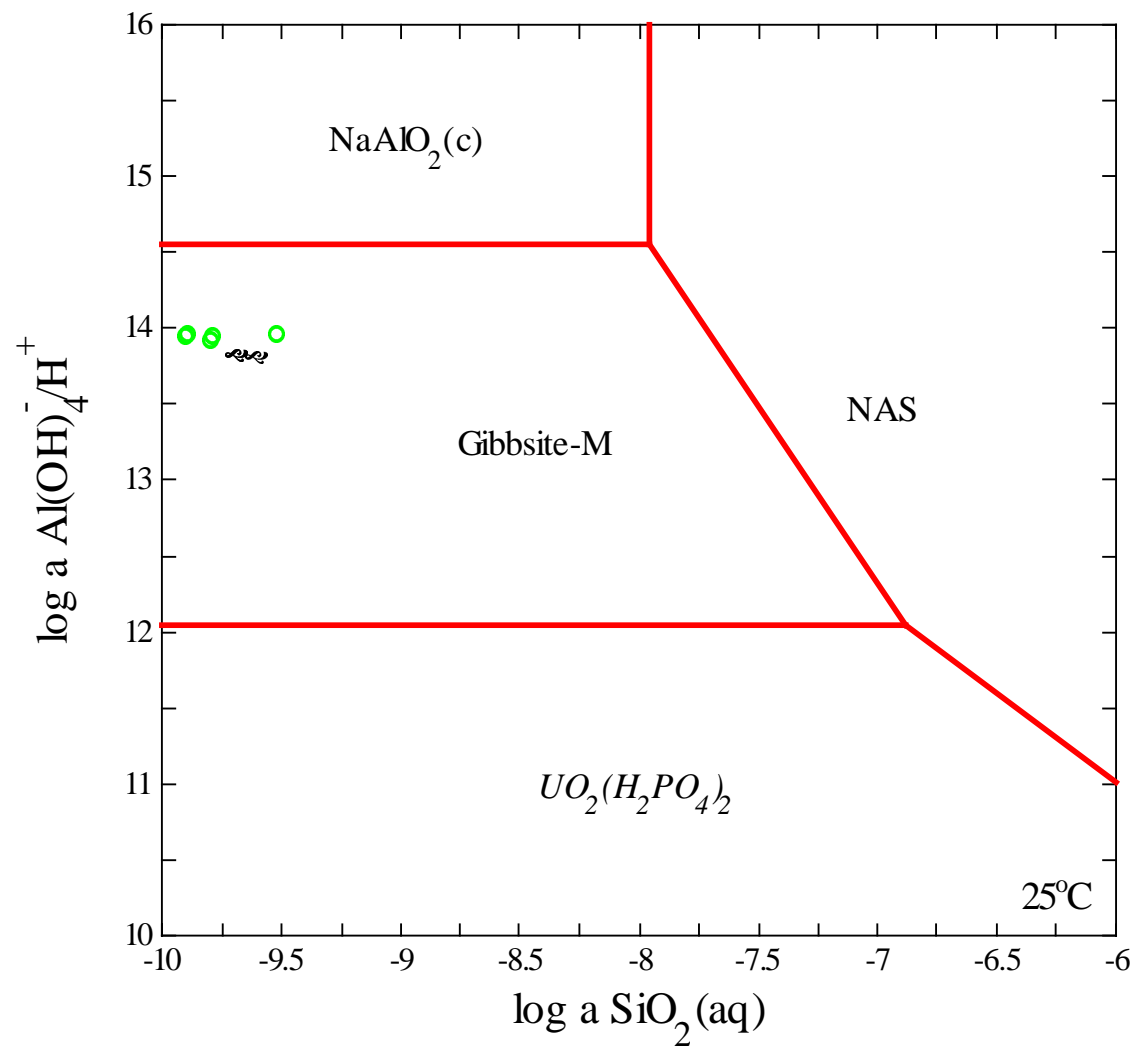

Figure 11. Activity diagram for Tank 30 samples (all depths) at $25^{\circ} \mathrm{C}$. The black circles are solution data from August 2000 and December 2000 including data taken after a transfer was made from Tank 40. The green stars are the solution data taken in February 2000 before Tank 30 was recycled to Tank 32. 


\subsection{Activity Diagrams at the Tank Temperature}

Activity diagrams were generated at the nominal temperature $\left(40^{\circ} \mathrm{C}\right)$ of the $\mathrm{SRS} 3 \mathrm{H}$ evaporator feed and drop tanks using the polythermal reaction option in GWB. The activity diagram shown in Figure 12 and Figure 13 indicate the dip and variable depth samples from Tank 32 (the feed tank) are in the stability field of gibbsite at the nominal tank temperatures. Figure 13 indicates that the samples taken within a few hours of the transfer from Tank 30 (the orange triangles) appear elevated in silica concentration but not to the point that it drives the solution equilibrium out of the gibbsite stability field and into the stability field of the NAS gel. Likewise Figure 14 indicates that the samples from various depths in Tank 30 (the drop tank) are in steady state equilibrium with gibbsite. Hence, neither the NAS gel, Zeolite-A, nor nitrated cancrinite/sodalite are anticipated to form in the SRS 3H Evaporator feed and drop tanks. Historic data for the feed tank (Tank 32) and the drop tank (Tank 30) from 1992 are shown for comparison in Figure 12 and Figure 14.

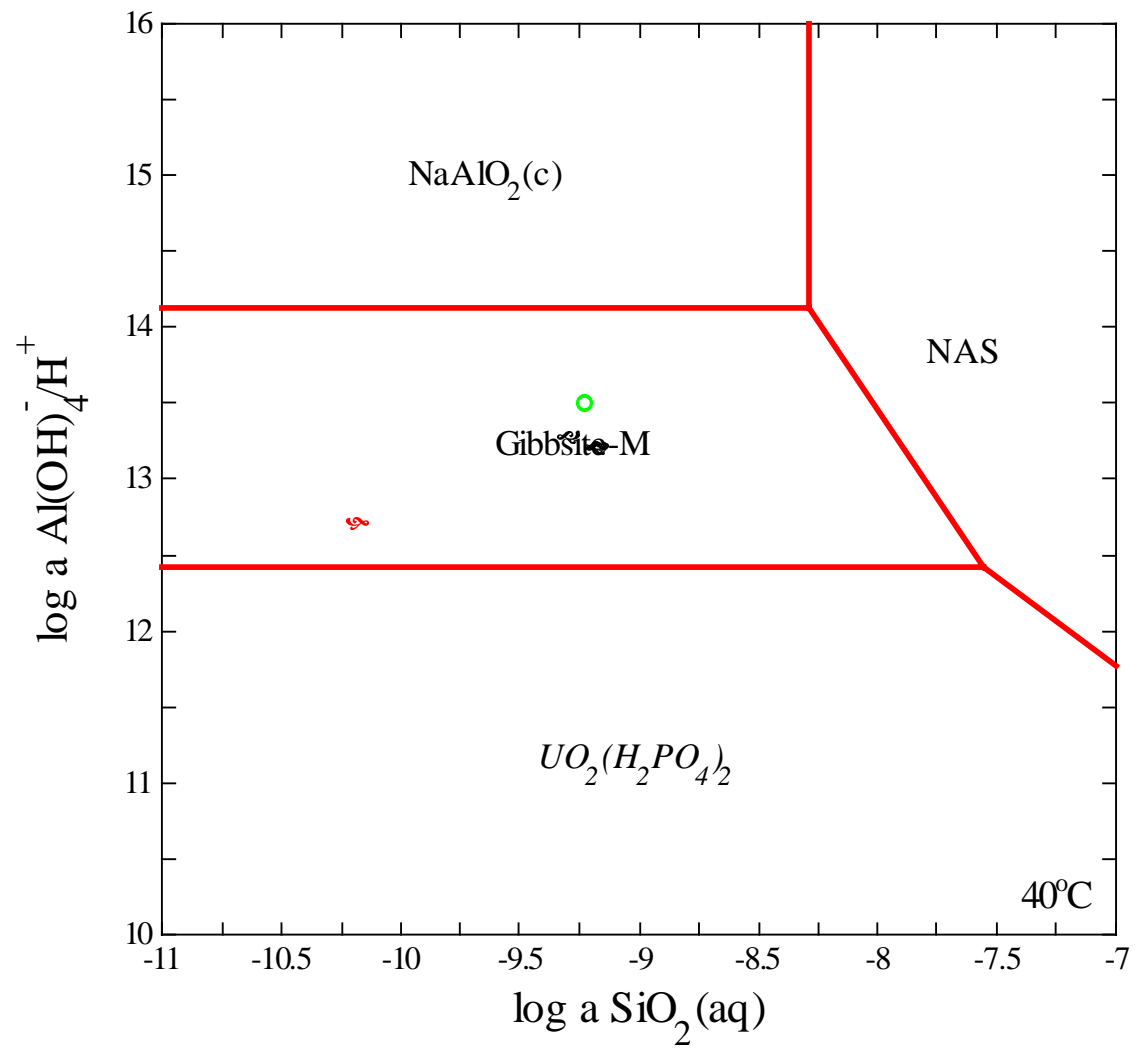

Figure 12. Activity diagram for dip sample (surface sample) compositions in Tank 32 (feed tank) at $40^{\circ} \mathrm{C}$. Black circles represent the solution analyses before recycle from Tank 30 and the green star represents the solution analysis after recycle from Tank 30. The red triangle represents historic data from 1992. 
WSRC-TR-2001-00155, Rev. 1

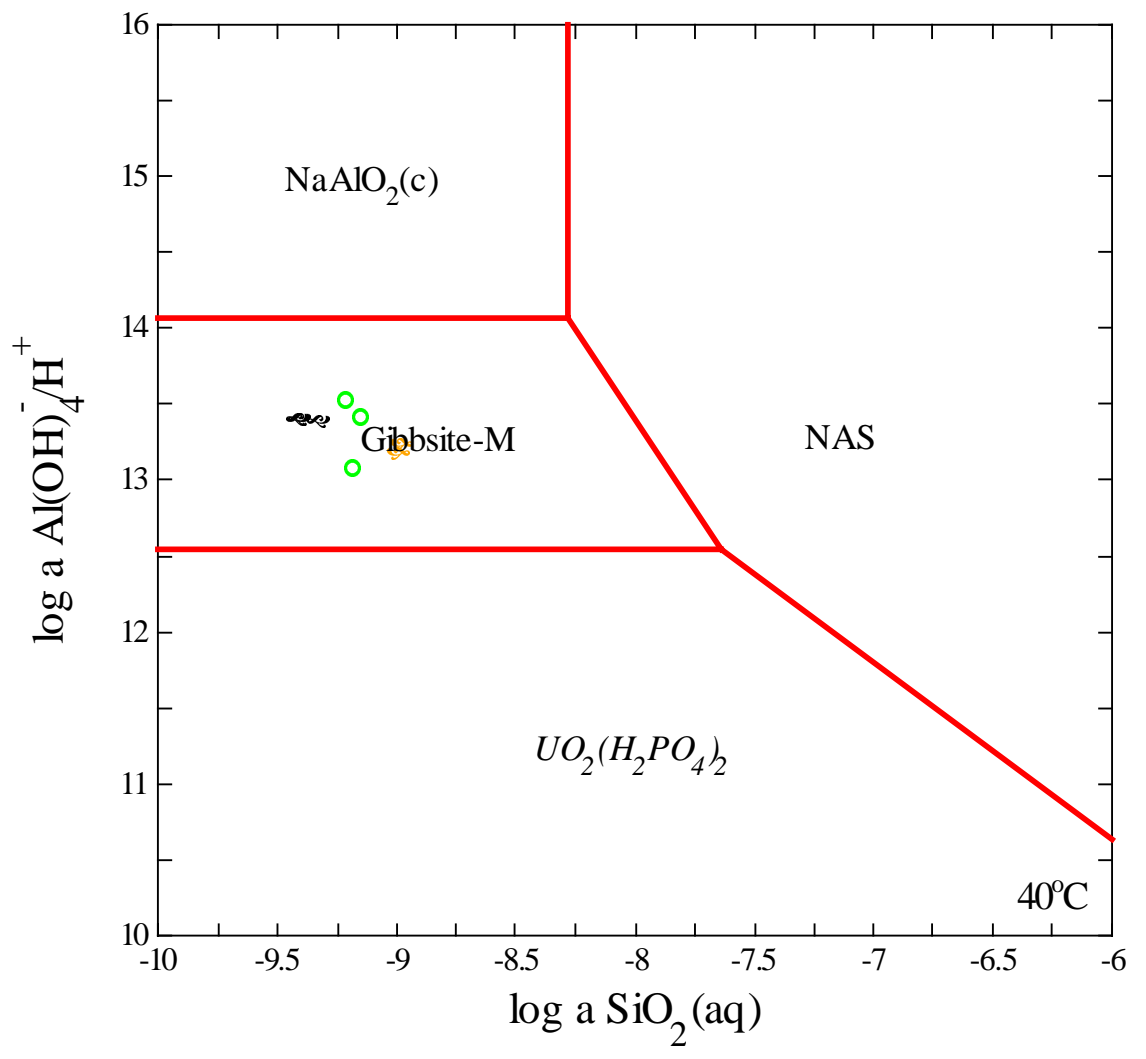

Figure 13. Activity diagram for variable depth sample compositions in Tank 32 (feed tank) at $40^{\circ} \mathrm{C}$. The black circles are solution data before recycle from Tank 30 . The green stars are the solution data after recycle from Tank 30 . The orange triangles are the samples from February 2000 that were taken at the height of the feed pump only a few hours after recycle from Tank 30 to Tank 32 . 
WSRC-TR-2001-00155, Rev. 1

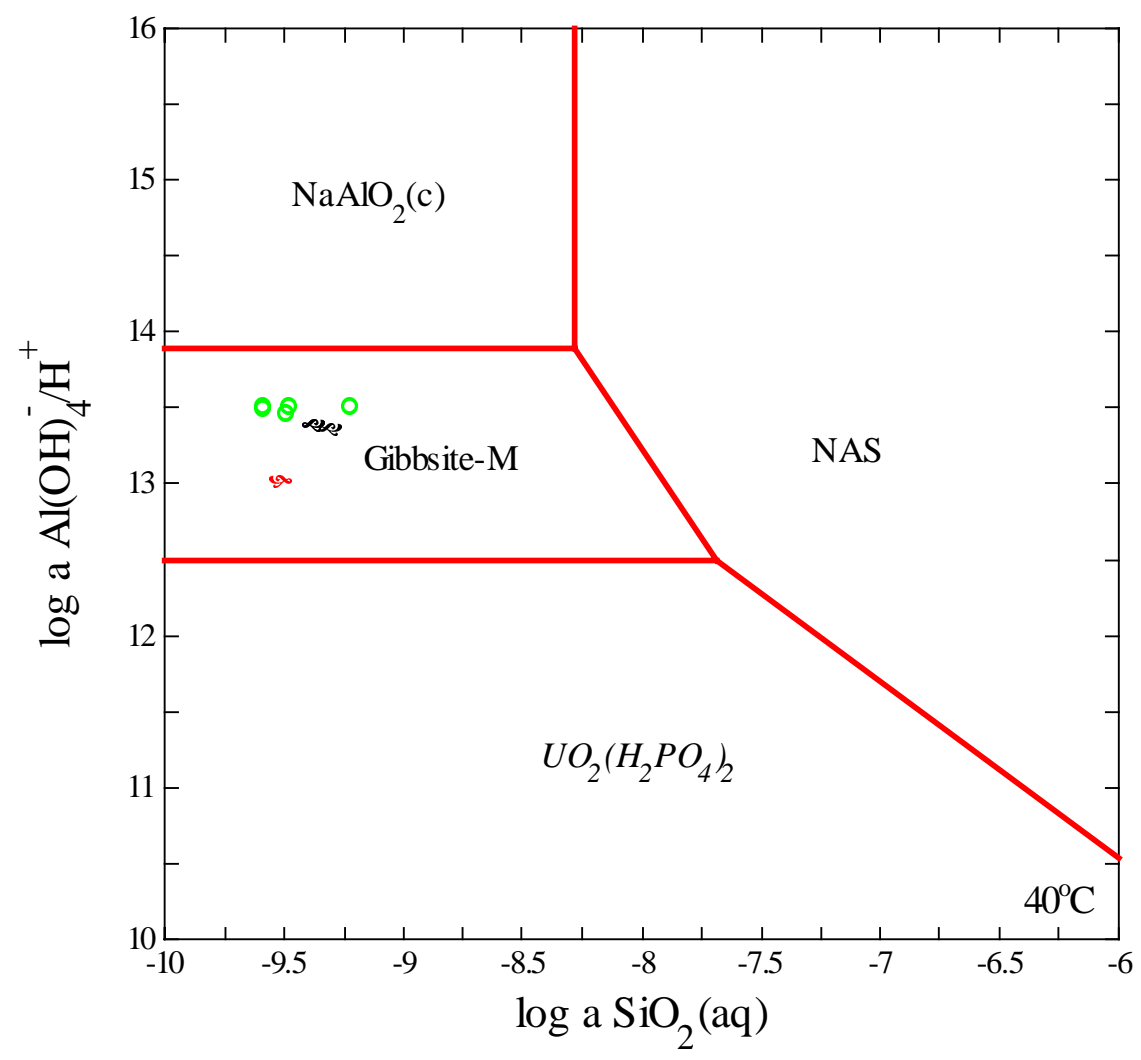

Figure 14. Activity diagram for Tank 30 samples (all depths) at $40^{\circ} \mathrm{C}$. The black circles are solution data from August 2000 and December 2000 including data taken after a transfer was made from Tank 40. The green stars are the solution data taken in February 2000 before Tank 30 was recycled to Tank 32. The red triangle is historic data from 1992.

\subsection{Activity Diagrams at the Evaporator Temperature}

Activity diagrams were generated at the elevated temperature $\left(140^{\circ} \mathrm{C}\right)$ of the $\mathrm{SRS} 3 \mathrm{H}$ evaporator using the polythermal reaction option in GWB. In this section the effects of elevated temperature on the relative phase stability fields are examined for solutions at a specific gravity of $\sim 1.45 \mathrm{~g} / \mathrm{cc}$, the nominal specific gravity achieved to date in the $3 \mathrm{H}$ Evaporator. The effects of an additional evaporation of $40 \%$ that would yield evaporator solutions of $\sim 1.6$ specific gravity are considered in Section 6.4.

At the elevated temperature of $140^{\circ} \mathrm{C}$, the gibbsite phase, $\mathrm{Al}(\mathrm{OH})_{3}$ is no longer stable. The mineral diaspore $(\mathrm{AlOOH})$ is the stable alumina phase at $140^{\circ} \mathrm{C}$. The higher iron 
concentrations in Table III for Tank 32 cause a field of precipitated (ppd) $\mathrm{Fe}(\mathrm{OH})_{3}$ to appear. The additional equilibria between diaspore, $\mathrm{NAS}, \mathrm{NaAlO}_{2}, \mathrm{UO}_{2}\left(\mathrm{H}_{2} \mathrm{PO}_{4}\right)_{2}$ and $\mathrm{Fe}(\mathrm{OH})_{3}$ are:

between $\mathrm{Fe}(\mathrm{OH})_{3}$ and diaspore

$$
2 \mathrm{Fe}(\mathrm{OH})_{3}(\mathrm{ppd})+\frac{\mathrm{Al}(\mathrm{OH})_{4}^{-}}{\mathrm{H}^{+}} \Leftrightarrow 2 \mathrm{Fe}(\mathrm{OH})_{4}^{-}+\text {Diaspore }
$$

between $\mathrm{Fe}(\mathrm{OH})_{3}$ and $\mathrm{NAS}$

$12 \mathrm{Fe}(\mathrm{OH})_{3}(\mathrm{ppd})+19 \mathrm{H}_{2} \mathrm{O}+12 \frac{\mathrm{Al}(\mathrm{OH})_{4}^{-}}{\mathrm{H}^{+}}+14 \mathrm{SiO}_{2}(\mathrm{aq})+12 \mathrm{Na}^{+} \Leftrightarrow \mathrm{NAS}+12 \mathrm{Fe}(\mathrm{OH})_{4}^{-}[10]$

between diaspore and NAS

6 Diaspore $+19 \mathrm{H}_{2} \mathrm{O}+6 \frac{\mathrm{Al}(\mathrm{OH})_{4}^{-}}{\mathrm{H}^{+}}+14 \mathrm{SiO}_{2}(\mathrm{aq})+12 \mathrm{Na}^{+} \Leftrightarrow \mathrm{NAS}$

between diaspore and $\mathrm{NaAlO}_{2}$

$$
\text { Diaspore }+\frac{\mathrm{Al}(\mathrm{OH})_{4}^{-}}{\mathrm{H}^{+}}+2 \mathrm{Na}^{+} \Leftrightarrow 2 \mathrm{NaAlO}_{2}(\mathrm{c})+2 \mathrm{H}_{2} \mathrm{O}
$$

and between diaspore and uranyl phosphate (aqueous)

$$
6 \mathrm{UO}_{2}\left(\mathrm{H}_{2} \mathrm{PO}_{4}\right)_{2}+19 \frac{\mathrm{Al}(\mathrm{OH})_{4}^{-}}{\mathrm{H}^{+}} \Leftrightarrow 19 \text { Diaspore }+24 \mathrm{H}_{2} \mathrm{O}+2\left(\mathrm{UO}_{2}\right)_{3}(\mathrm{OH})_{7}^{-}+12 \mathrm{PO}_{4}^{3-}[13]
$$

Neither crystalline $\mathrm{Al}(\mathrm{OH})_{3}$ nor $\mathrm{Fe}(\mathrm{OH})_{3}$ are predicted to actually form in the evaporator because the evaporator residence times are too short and the kinetics of formation of these species is on the order of weeks. Indeed, the formation of amorphous $\mathrm{Fe}(\mathrm{OH})_{3}$ is metastable. ${ }^{50}$ However, the higher iron and silica concentrations are well correlated with the time at which the VDS samples were taken relative to a recycle from Tank 30 to Tank 32, i.e. within hours of the recycle (February 2000) and during the tank recycle (September 2000). This indicates that the frequent recycles from Tank 30 to Tank 32 are mixing the feed tank contents and potentially sending more insoluble and/or colloidal silica and iron to the $3 \mathrm{H}$ Evaporator than necessary.

Ejaz. ${ }^{22}$ has suggested that the NAS phase may not be the stable phase at elevated temperature due to the rapid kinetics of the NAS transformation into Zeolite-A and other phases. This hypothesis was put forward by Ejaz although he did not have data to 


\section{WSRC-TR-2001-00155, Rev. 1}

substantiate his position. A mixture of Zeolite-A and hydroxysodalite, such as that observed by Gasteiger et. al. ${ }^{17}$ at $95^{\circ} \mathrm{C}$ in evaporators in the paper and pulp industry, is more likely at $140^{\circ} \mathrm{C}$. Therefore, the activity diagrams showing the equilibrium with NAS gel will be presented pairwise with the activity diagrams showing the equilibrium with the Gasteiger mixed zeolite. It should be noted that the solubility data of Ejaz ${ }^{22}$ for the NAS gel and the solubility data of Gasteiger ${ }^{17}$ are very similar and confirmatory of each other. However, each of these diagrams is based on solubility extrapolations as discussed in Section 5.0, i.e. the solubility of the NAS gel has been extrapolated from the lower temperature measurements of Ejaz. ${ }^{22}$ For the mixed zeolite phase of Gasteiger, ${ }^{17}$ solubility was available for only one temperature, $95^{\circ} \mathrm{C}$, and the temperature dependence of the solubility of the mixed zeolite was estimated using the activation energy of the NAS gel.

The activity diagrams for the SRS $3 \mathrm{H}$ Evaporator solutions at $140^{\circ} \mathrm{C}$ for the dip (surface) sample populations in the feed tank (Tank 32) are shown in Figure 15a and Figure 15b. Figure 15a shows that the solutions are saturated with respect to $\mathrm{Fe}(\mathrm{OH})_{3}$ and will not precipitate NAS. Likewise, Figure $15 \mathrm{~b}$ demonstrates that the solutions saturated with respect to $\mathrm{Fe}(\mathrm{OH})_{3}$ and not the mixed zeolite phase. Since the $\mathrm{Fe}(\mathrm{OH})_{3}$ phase is metastable ${ }^{50}$ this phase was suppressed in Figure 15c, Figure 15d, and subsequent figures. Figure $15 \mathrm{c}$ demonstrates that the SRS $3 \mathrm{H}$ Evaporator solutions at $140^{\circ} \mathrm{C}$ for the dip (surface) sample populations in the feed tank are saturated with respect to diaspore and not NAS gel. This does not mean that diaspore is precipitating since the kinetics of diaspore formation is on the order of weeks. Figure 15d indicates that the SRS $3 \mathrm{H}$ Evaporator solutions at $140^{\circ} \mathrm{C}$ are also not in the stability field of mixed zeolite.

The activity diagrams for the SRS $3 \mathrm{H}$ Evaporator solutions at $140^{\circ} \mathrm{C}$ for the variable depth sample (VDS) populations in the feed tank (Tank 32) are shown in Figure 16a and Figure 16b. Both these figures show that the solutions are saturated with respect to diaspore and will not precipitate NAS or mixed zeolite in the evaporator.

The activity diagrams for the SRS $3 \mathrm{H}$ Evaporator solutions at $140^{\circ} \mathrm{C}$ for all the depth samples in the drop tank (Tank 30) are shown in Figure 17a and Figure 17b. All of the samples are saturated with respect to diaspore and neither NAS gel nor mixed zeolite will form.

\subsection{Activity Diagrams at the Evaporator Temperature With Simulated Evaporation}

The activity diagrams for the SRS $3 \mathrm{H}$ Evaporator solutions at $140^{\circ} \mathrm{C}$ with a simulated 40\% evaporation are shown in Figure 18 and Figure 19. The simulated $40 \%$ evaporation would take the specific gravity of the solution from 1.4 to $1.6 \mathrm{~g} / \mathrm{cm}^{3}$ which is the nominal operating target for the evaporators. The historic data through February 2000 indicates that the evaporators have not concentrated above about $1.45 \mathrm{~g} / \mathrm{cc}$ (see Table III and Table IV). 
Activity diagrams for the dip (surface) sample populations in the feed tank (Tank 32) are shown in Figure 18a and Figure 18b. These figures show that the dip solutions remain in steady state equilibrium with diaspore even after $40 \%$ simulated evaporation. The activity diagrams for the SRS $3 \mathrm{H}$ Evaporator solutions at $140^{\circ} \mathrm{C}$ for the variable depth sample (VDS) populations in the feed tank (Tank 32) are shown for comparison in Figure 19a and Figure 19b. Figure 19 shows that the solutions remain in the stability field of diaspore after a simulated $40 \%$ evaporation.

\subsection{POTENTIAL FOR DEPOSITION IN THE SRS 3H EVAPORATOR}

Modeling the SRS $3 \mathrm{H}$ Evaporator solutions at $140^{\circ} \mathrm{C}$ with and without simulated evaporation demonstrated that the solutions were at steady state equilibrium with diaspore and/or $\mathrm{Fe}(\mathrm{OH})_{3}$ and not with NAS, the precursor to nitrated sodalite/cancrinite precipitation. Even an additional $40 \%$ evaporation did not cause the evaporator solutions to be supersaturated with respect to mixed zeolite (Figure 18b and Figure 19b).

The GWB subroutine REACT which is used to calculate the solution activities plotted on the activity diagrams can also calculate the degree of supersaturation of a solution with respect to all the phases of interest and/or the number of kilograms of solid that would precipitate per kilogram of solution. The degree of supersaturation is expressed as a ratio designated as $\mathrm{Q} / \mathrm{K}$ where $\mathrm{Q}$ is the reaction quotient (calculated equilibrium constant) of the evaporator solution being modeled and $\mathrm{K}$ is the theoretical equilibrium constant at saturation. Table VII lists the $\log \mathrm{Q} / \mathrm{K}$ values from the REACT calculations. A negative number in Table VII indicates that a solution is undersaturated with respect to the aluminosilicate NAS gel and/or mixed zeolite. A positive number indicates supersaturation with respect to the aluminosilicate NAS gel and/or mixed zeolite formation.

The results in Table VII agree with the data in Figure 12-Figure 19 and demonstrate that the tank supernates are not supersaturated with respect to aluminosilicate (NAS gel or mixed zeolite) at $40^{\circ} \mathrm{C}$, at $140^{\circ} \mathrm{C}$ in the absence of evaporation, or at $140^{\circ} \mathrm{C}$ with an additional $40 \%$ evaporation. The $\mathrm{Q} / \mathrm{K}$ ratios in Table VII are in agreement with the aluminosilicate $\mathrm{K}_{\mathrm{sp}}$ determined experimentally and recently used by Wilmarth ${ }^{36}{ }^{37}$ to determine the acceptability of supernates for processing in the SRS 3H Evaporator, e.g., if the $[\mathrm{Al}]^{*}[\mathrm{Si}]$ in $\mathrm{M}^{2}$ is in the $2 \times 10^{-4}$ to $8 \times 10^{-4}$ range then the supernates are acceptable for processing in the SRS evaporators. The values for this $\mathrm{K}_{\mathrm{sp}}$ based on room temperature chemical data are shown in Table VII for comparison. The relative supersaturation of the solutions in the SRS $2 \mathrm{H}$ and $3 \mathrm{H}$ Evaporators is discussed in Part I. ${ }^{3}$ 
WSRC-TR-2001-00155, Rev. 1

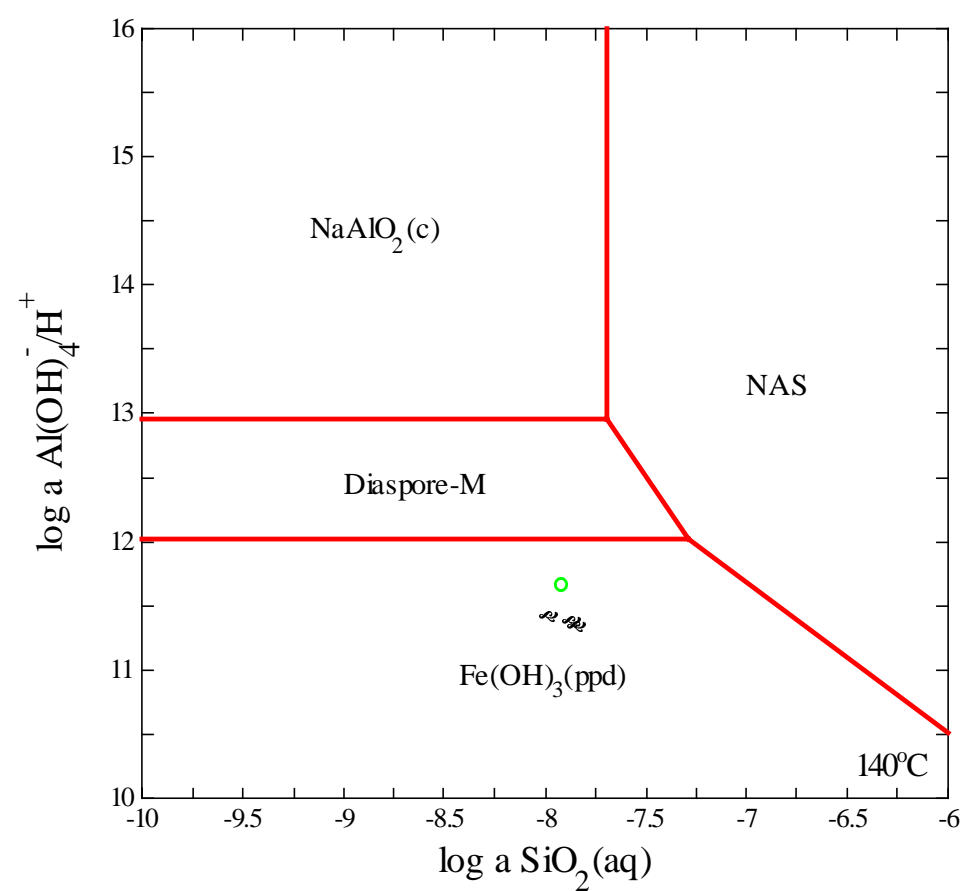

Figure 15a. Activity diagram for dip sample (surface sample) compositions in Tank 32 (feed tank) at $140^{\circ} \mathrm{C}$ (no simulated evaporation). Equilibrium being modeled is that between Diaspore (AlOOH) and NAS gel. Black circles represent the solution analyses before recycle from Tank 30 and the green stars represent the solution analyses after recycle from Tank 30.

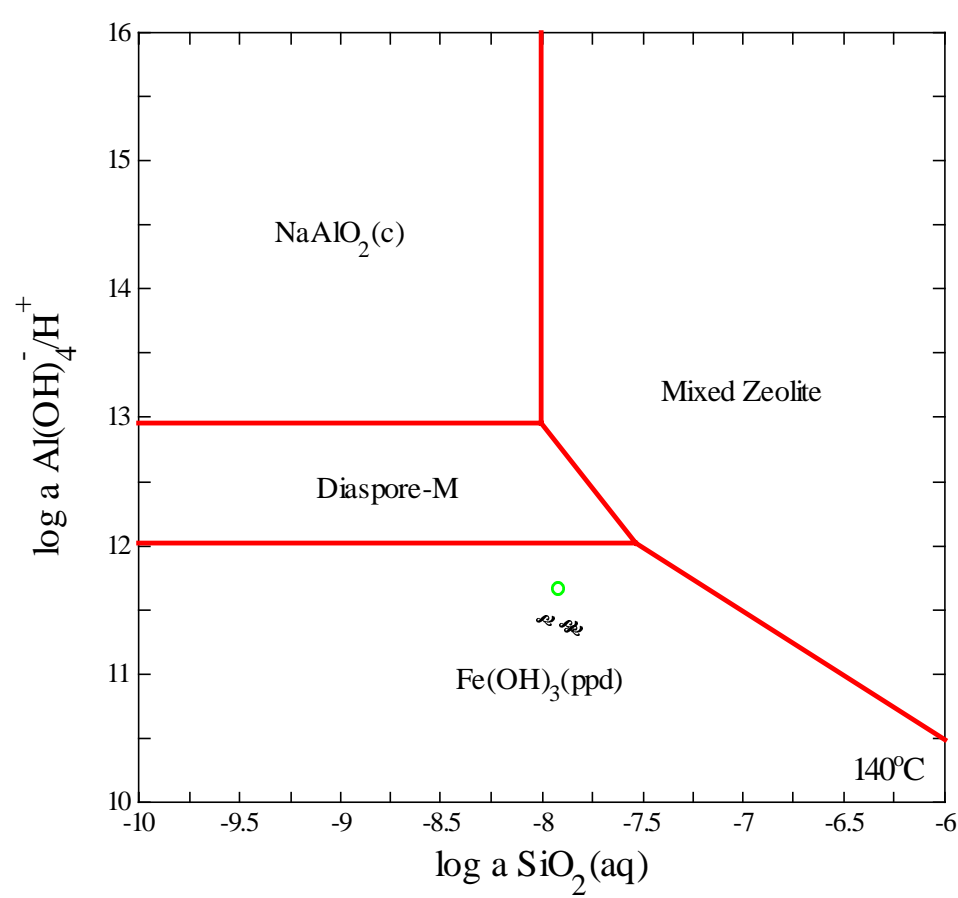

Figure 15b. Activity diagram for dip sample (surface sample) compositions in Tank 32 (feed tank) at $140^{\circ} \mathrm{C}$ (no simulated evaporation). Equilibrium being modeled is that between Diaspore (AlOOH) and mixed zeolite. Black circles represent the solution analyses before recycle from Tank 30 and the green stars represent the solution analyses after recycle from Tank 30. 
WSRC-TR-2001-00155, Rev. 1

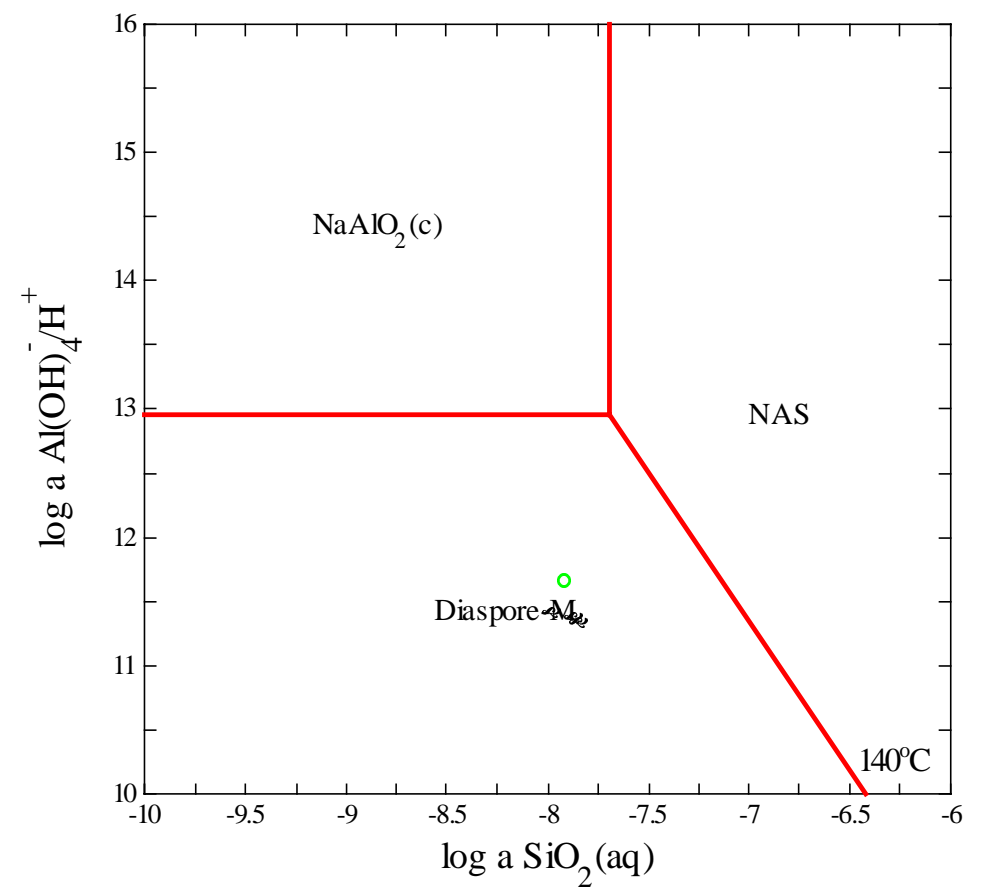

Figure 15c. Activity diagram for dip sample (surface sample) compositions in Tank 32 (feed tank) at $140^{\circ} \mathrm{C}$ (no simulated evaporation) with $\mathrm{Fe}(\mathrm{OH})_{3}$ formation suppressed. Equilibrium being modeled is that between Diaspore $(\mathrm{AlOOH})$ and NAS gel. Black circles represent the solution analyses before recycle from Tank 30 and the green stars represent the solution analyses after recycle from Tank 30.

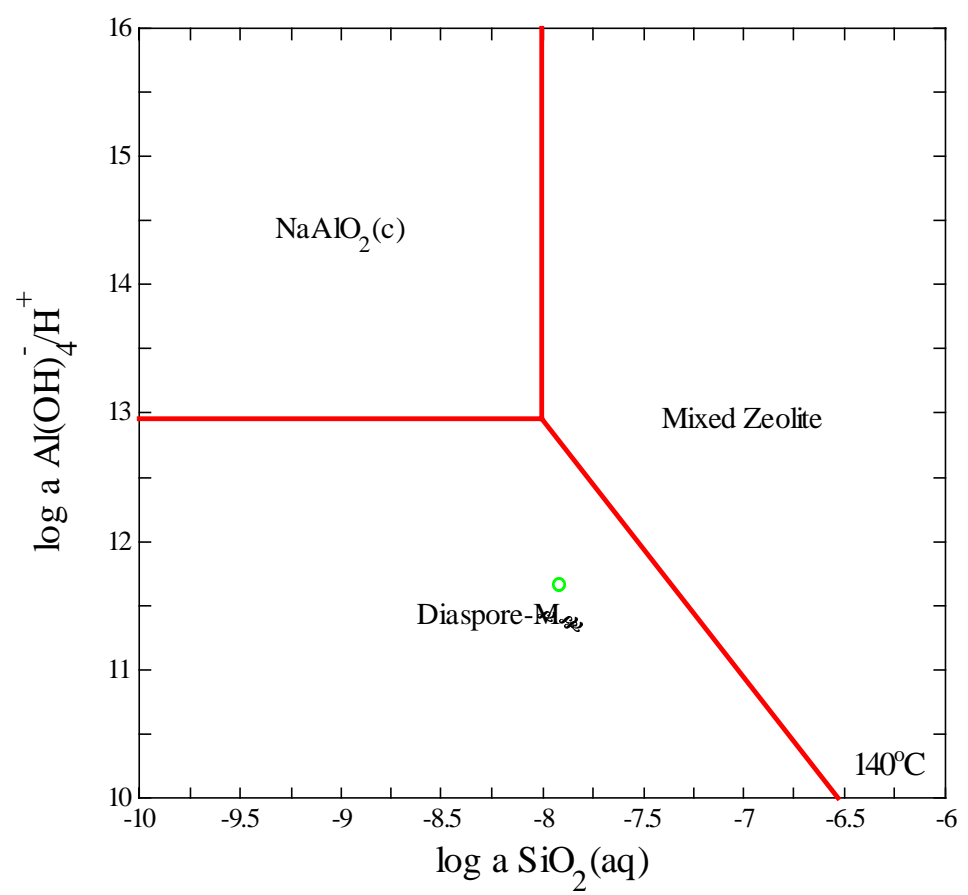

Figure 15d. Activity diagram for dip sample (surface sample) compositions in Tank 32 (feed tank) at $140^{\circ} \mathrm{C}$ (no simulated evaporation) with $\mathrm{Fe}(\mathrm{OH})_{3}$ formation suppressed. Equilibrium being modeled is that between Diaspore $(\mathrm{AlOOH})$ and mixed zeolite. Black circles represent the solution analyses before recycle from Tank 30 and the green stars represent the solution analyses after recycle from Tank 30. 
WSRC-TR-2001-00155, Rev. 1

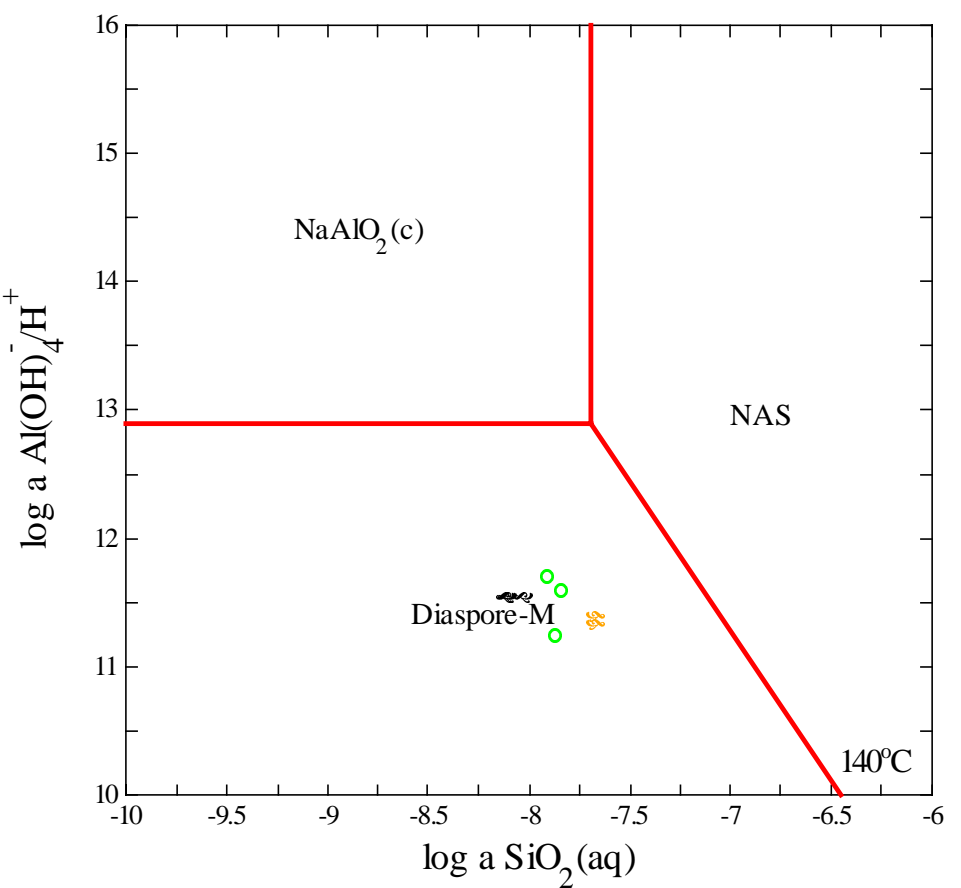

Figure 16a. Activity diagram for Tank 32 variable depth samples at $140^{\circ} \mathrm{C}$ before and after recycle from Tank 30 (no simulated evaporation) with $\mathrm{Fe}(\mathrm{OH})_{3}$ formation suppressed. Equilibrium being modeled is that between Diaspore (AlOOH) and NAS gel.

The black circles are solution data before recycle. The green stars are the solution data after recycle from Tank 30. The orange triangles are the samples from February 2000 that were taken at the height of the feed pump only a few hours after recycle from Tank 30 to Tank 32 .

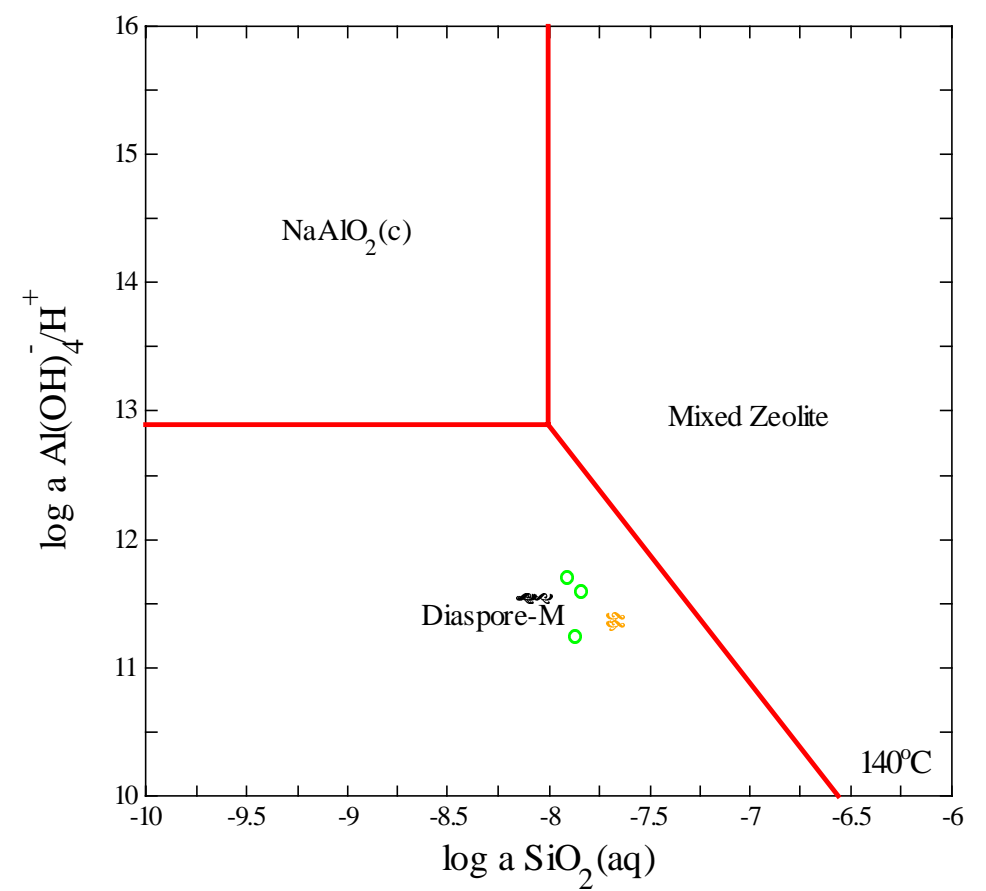

Figure 16b. Activity diagram for Tank 32 variable depth samples at $140^{\circ} \mathrm{C}$ before and after recycle from Tank 30 (no simulated evaporation) with $\mathrm{Fe}(\mathrm{OH})_{3}$ formation suppressed. Equilibrium being modeled is that between Diaspore $(\mathrm{AlOOH})$ and mixed zeolite. The black circles are solution data before recycle. The green stars are the solution data after recycle from Tank 30. The orange triangles are the samples from February 2000 that were taken at the height of the feed pump only a few hours after recycle from Tank 30 to Tank 32. 
WSRC-TR-2001-00155, Rev. 1

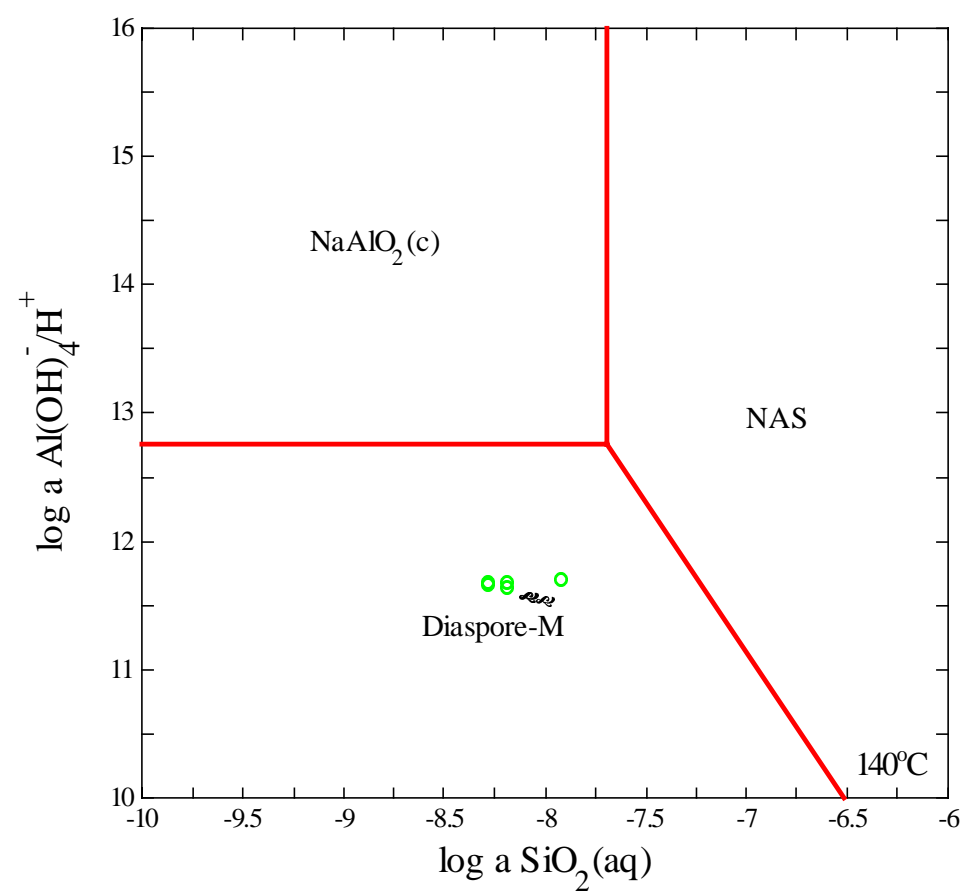

Figure 17a. Activity diagram for Tank 30 samples (all depths) at $140^{\circ} \mathrm{C}$ (no simulated evaporation) with the formation of $\mathrm{Fe}(\mathrm{OH})_{3}$ suppressed. Equilibrium being modeled is that between Diaspore (AlOOH) and NAS gel.

The black circles are solution data before recycle.

The black circles are solution data from August 2000 and December 2000 including data taken after a transfer was made from Tank 40 . The green stars are the solution data taken in February 2000 before Tank 30 was recycled to Tank 32 .

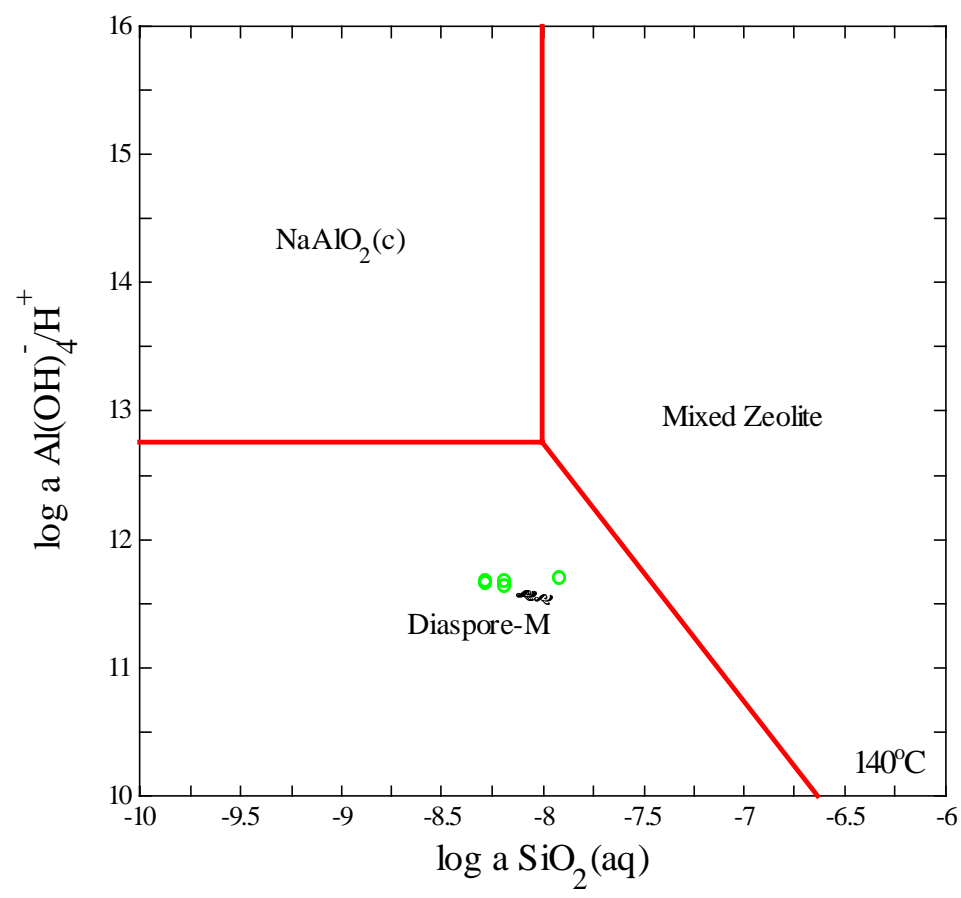

Figure 17b. Activity diagram for Tank 30 samples (all depths) at $140^{\circ} \mathrm{C}$ (no simulated evaporation) with the formation of $\mathrm{Fe}(\mathrm{OH})_{3}$ suppressed. Equilibrium being modeled is that between Diaspore (AlOOH) and mixed zeolite. The black circles are solution data before recycle. The black circles are solution data from August 2000 and December 2000 including data taken after a transfer was made from Tank 40. The green stars are the solution data taken in February 2000 before Tank 30 was recycled to Tank 32 . 
WSRC-TR-2001-00155, Rev. 1

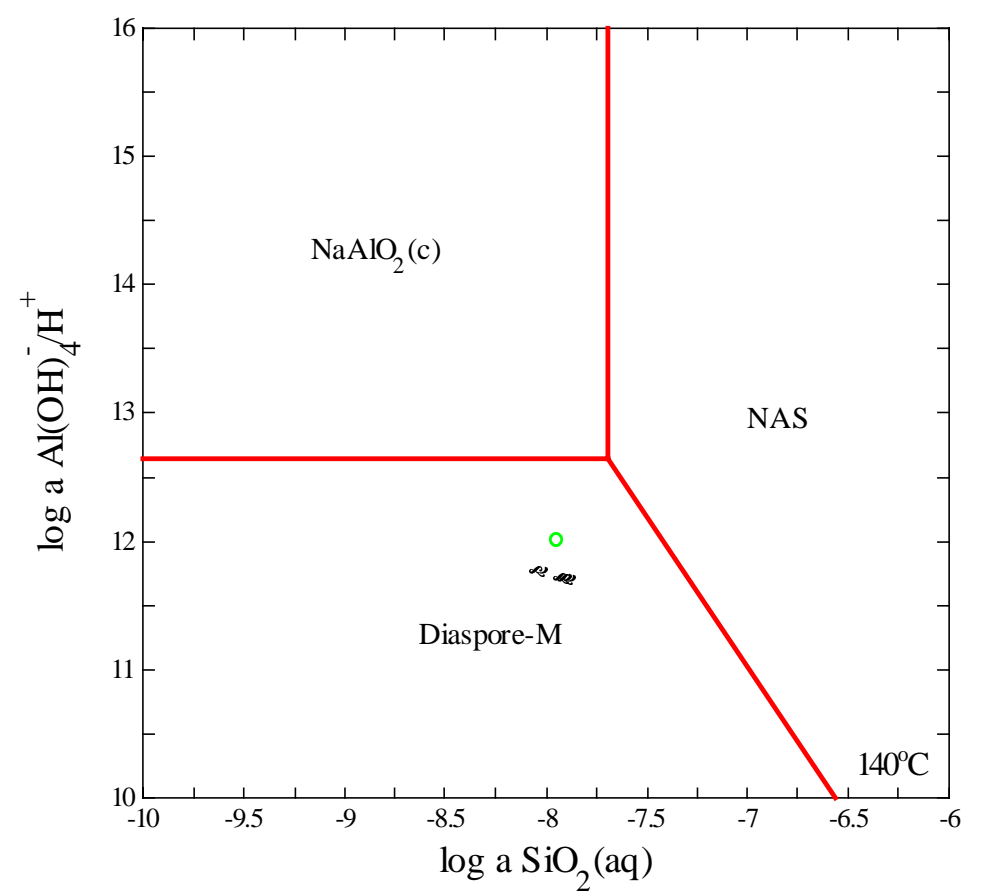

Figure 18a. Activity diagram for dip sample (surface sample) compositions in Tank 32 (feed tank) at $140^{\circ} \mathrm{C}$ (with $40 \%$ simulated evaporation) with the formation of $\mathrm{Fe}(\mathrm{OH})_{3}$ suppressed. Equilibrium being modeled it that between Diaspore (AlOOH) and NAS gel.

Black circles represent the solution analyses before recycle from Tank 30 and the green stars represent the solution analyses after recycle from Tank 30.

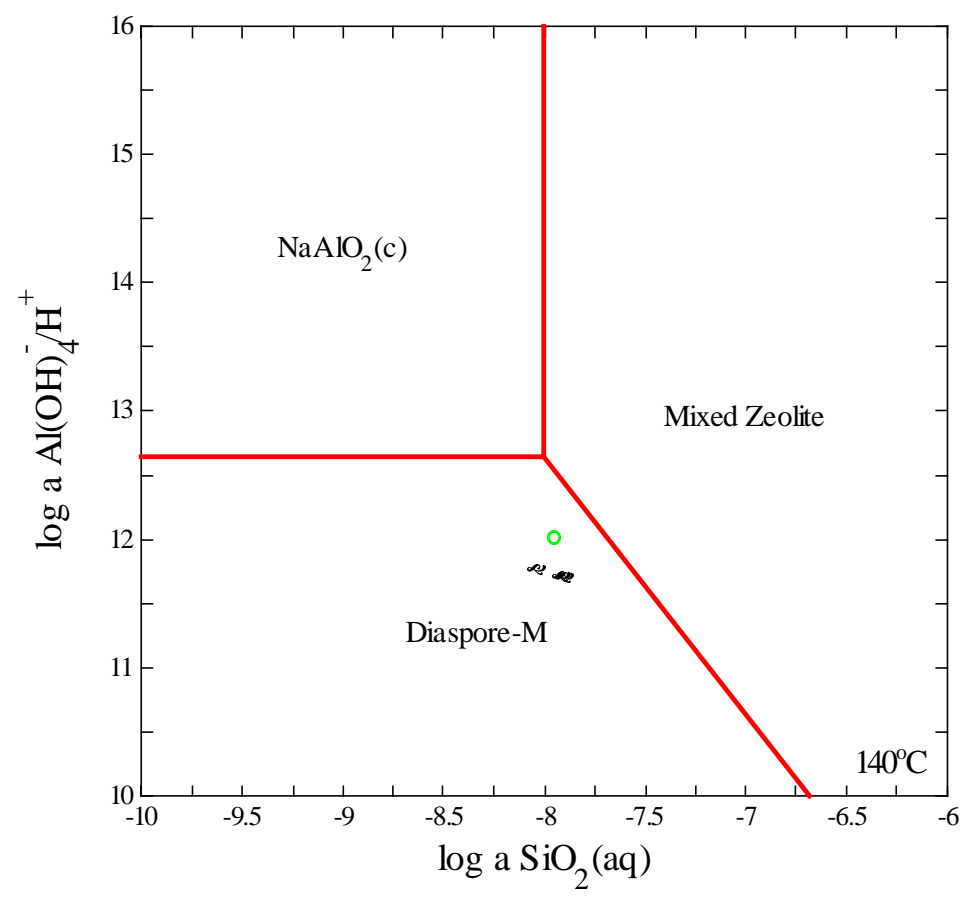

Figure 18b. Activity diagram for dip sample (surface sample) compositions in Tank 32 (feed tank) at $140^{\circ} \mathrm{C}$ (with $40 \%$ simulated evaporation) with the formation of $\mathrm{Fe}(\mathrm{OH})_{3}$ suppressed. Equilibrium being modeled it that between Diaspore (AlOOH) and mixed zeolite. Black circles represent the solution analyses before recycle from Tank 30 and the green stars represent the solution analyses after recycle from Tank 30. 
WSRC-TR-2001-00155, Rev. 1

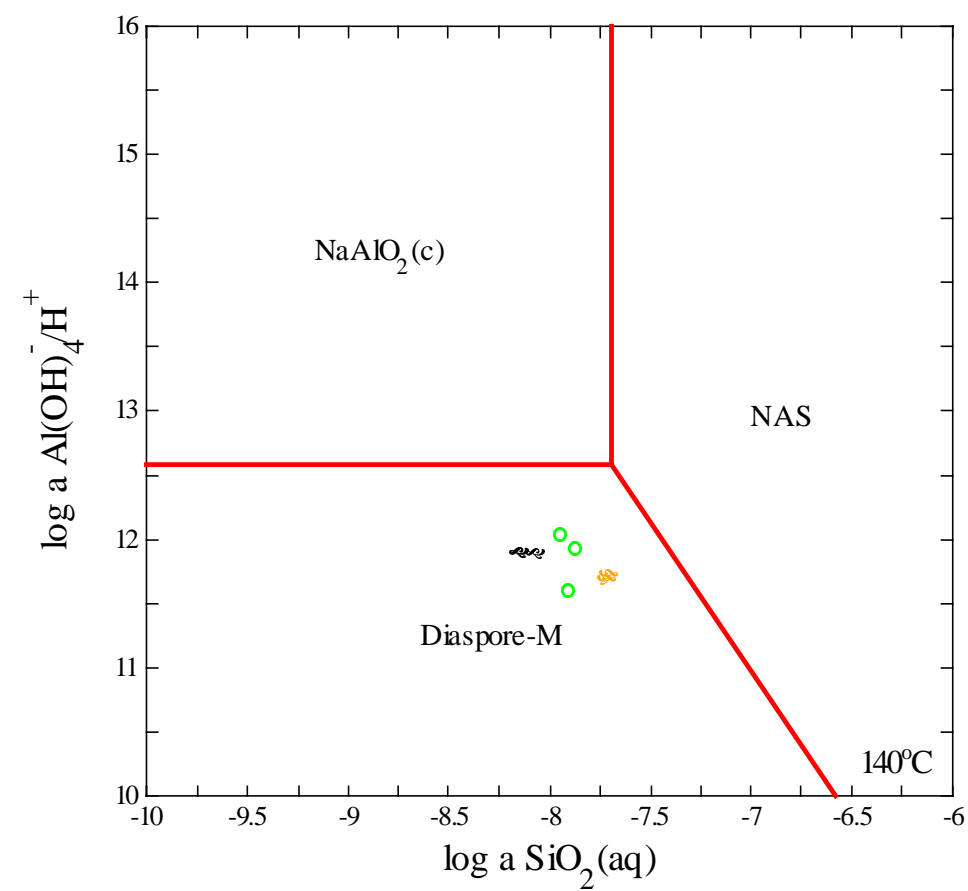

Figure 19a. Activity diagram for Tank 32 variable depth samples at $140^{\circ} \mathrm{C}$ before and after recycle from Tank 30 (with $40 \%$ simulated evaporation) with the formation of $\mathrm{Fe}(\mathrm{OH})_{3}$ suppressed. Equilibrium being modeled is that between Diaspore $(\mathrm{AlOOH})$ and NAS gel. The black circles are solution data before recycle. The green stars are the solution data after recycle from Tank 30 . The orange triangles are the samples from February 2000 that were taken at the height of the feed pump only a few hours after recycle from Tank 30 to Tank 32.

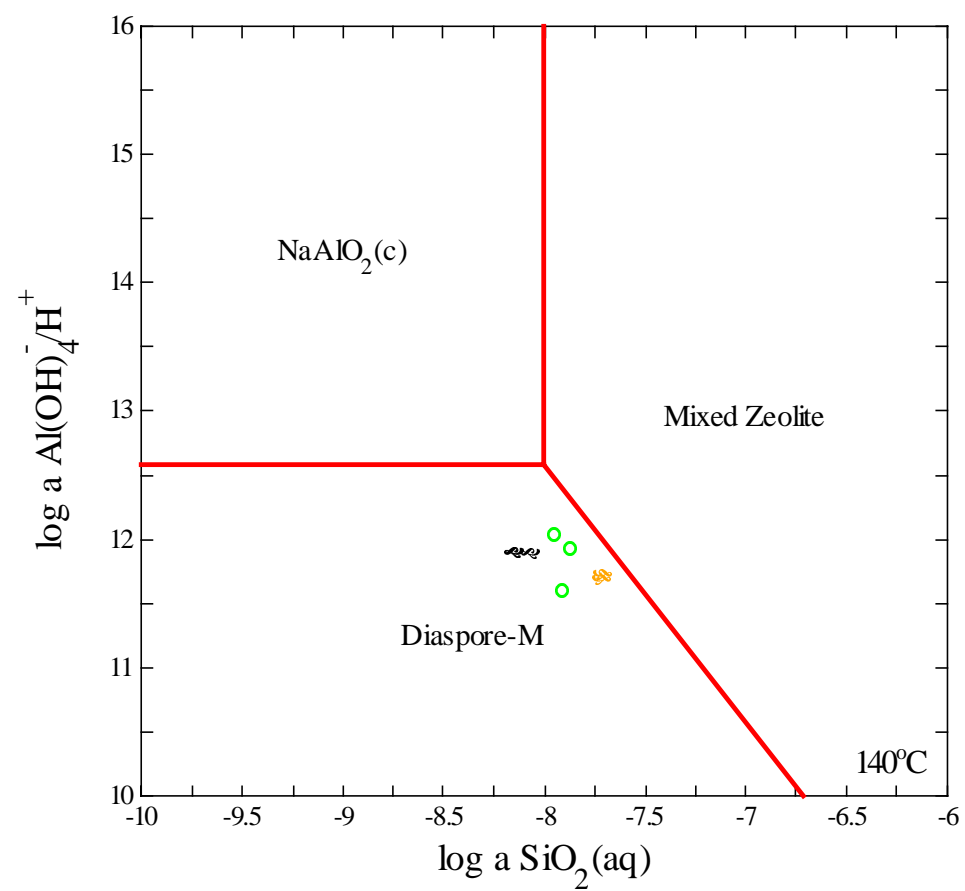

Figure 19b.Activity diagram for Tank 32 variable depth samples at $140^{\circ} \mathrm{C}$ before and after recycle from Tank 30 (with $40 \%$ simulated evaporation) with the formation of $\mathrm{Fe}(\mathrm{OH})_{3}$ suppressed. Equilibrium being modeled is that between Diaspore (AlOOH) and mixed zeolite. The black circles are solution data before recycle. The green stars are the solution data after recycle from Tank 30. The orange triangles are the samples from February 2000 that were taken at the height of the feed pump only a few hours after recycle from Tank 30 to Tank 32. 
While there is no evidence that the SRS 3H Evaporator system is supersaturated with respect to the precipitation of NAS and hence nitrated sodalite/cancrinite, there is evidence that Tank 30 (the drop tank) has a layer of entrained sludge or precipitated $\mathrm{Fe}(\mathrm{OH})_{3}$ and silica sol deposits at the bottom. This is based on the analysis completed by Wilmarth ${ }^{36}$ of a "salt" sample taken from 8" above the Tank 30 (drop tank) floor that was enriched in silica four times (4X) compared to the sample taken 348" above the bottom of the tank and enriched in silica two times (2X) compared to the sample taken 179" above the bottom of the tank in August 2000. This demonstrates the following:

- the transfer jet in Tank 30 that is 4" above the floor needs to be higher in the tank so that entrained sludge solids, precipitated $\mathrm{Fe}(\mathrm{OH})_{3}$ and/or silica sol deposits are not recycled to Tank 32

The formation and supersaturation of the $\mathrm{Na}_{2} \mathrm{U}_{2} \mathrm{O}_{7}$ phase has not been modeled in this study since it is known from the work of Hobbs and Karraker ${ }^{35}$ and Peterson and Pierce ${ }^{51}$ that the evaporator solutions can be supersaturated with respect to this phase. In the absence of the NAS phase, 40 years of operational experience at SRS indicates that the $\mathrm{Na}_{2} \mathrm{U}_{2} \mathrm{O}_{7}$ phase does not accumulate in the evaporator. 
WSRC-TR-2001-00155, Rev. 1

Table VII. Supersaturation of 3H Evaporator Solutions with Respect to Aluminosilicate Formation

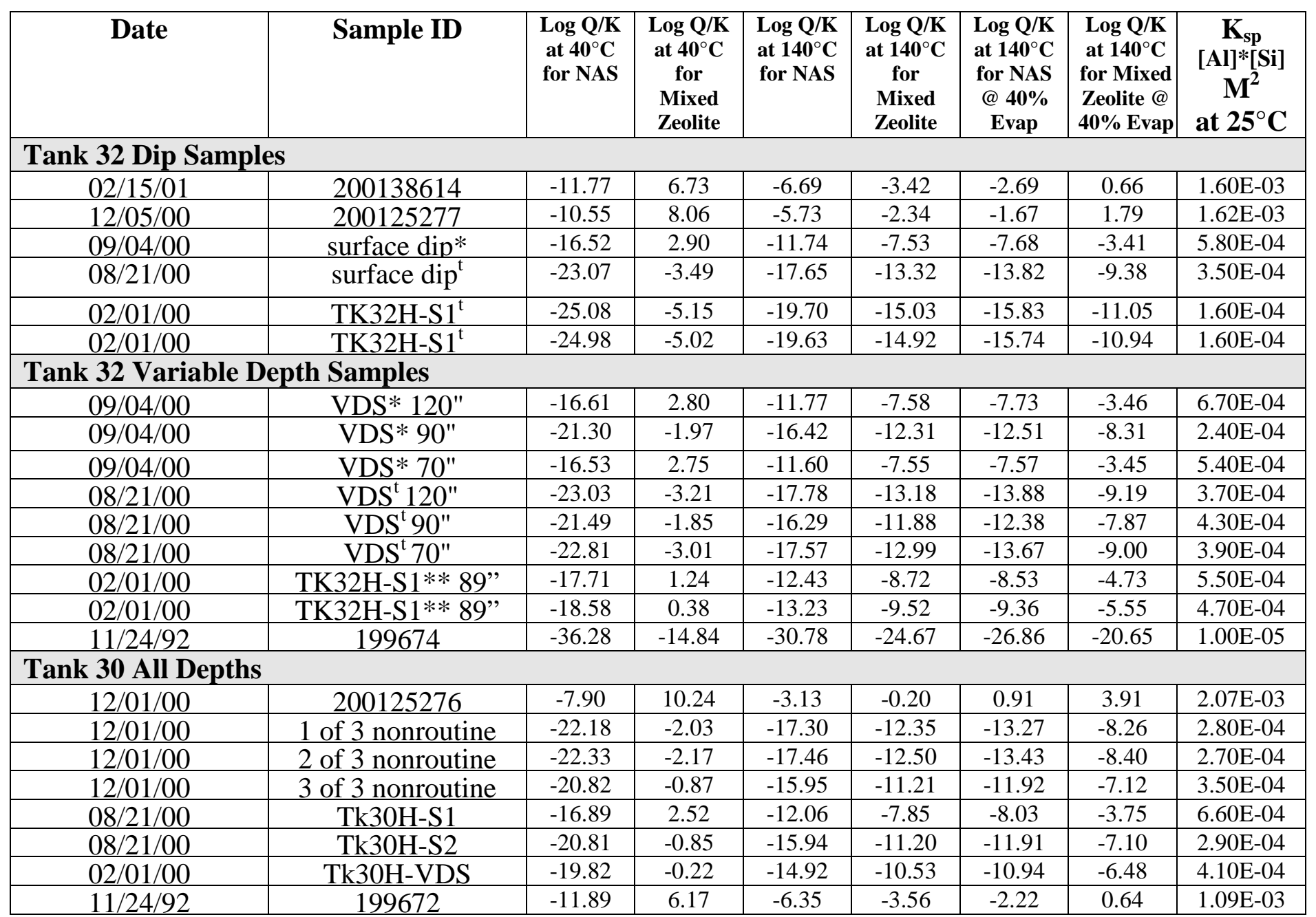

$*=$ after recycle of Tank 30 to Tank $32 ; \mathrm{t}=$ before recycle of Tank 30 to Tank 32; ** = within a few hours of a recycle of Tank 30 to 32 


\section{WSRC-TR-2001-00155, Rev. 1}

\subsection{CONCLUSIONS}

- Based on the latest available accurate data for the SRS 3H Evaporator feed tank (September 2000), the SRS 3H Evaporator is not precipitating sodium aluminosilicate (NAS) phases.

- Continued recycle and transfers from the bottom of the drop tank (Tank 30) back to the feed tank (Tank 32) may cause sodium aluminosilicates to supersaturate beyond the present levels. (Implemented in Spring 2001 when the transfer jet was replaced at a height of 150" above the tank floor.)

- The analytical data indicate that the frequent recycles from Tank 30 to Tank 32 at a level beneath the sludge layer are stirring and/or agitating the feed tank contents creating a "Zone of Turbidity" that has the potential to add extra silica and iron to the feed tank if not allowed to settle for 5-6 hours after a transfer.

- $\quad$ The extra silica and iron are recycled through $3 H$ Evaporator if not allowed to settle out in the feed tank where they can initiate deposits.

- The "salt" layer in Tank 30 has elevated levels of silica (4X), Al, Fe and Mn compared to the remaining supernate indicating that $\mathrm{Fe}(\mathrm{OH})_{3}$, silica sol deposits, and possibly other sludge hydroxides may have precipitated in the drop tank. This could also be from the one small sludge transfer made to this tank in September 1996.

- A more accurate Si analysis method must be implemented in the F-Area laboratory immediately.

- Recent (December 2000 and January 2001) F-area laboratory silicon analyses are biased high.

- Routine analytic samples, if used for confirmatory modeling, must be taken at the height of the feed pump.

- Modeling can be confounded if data taken close to the sludge layer and data taken during tank transfers or within several hours of tank recycles is modeled.

- Feed tank and drop tank supernate solutions modeled at $25^{\circ} \mathrm{C}$ and $40^{\circ} \mathrm{C}$ are not supersaturated with respect to sodium aluminosilicate (NAS) formation.

- Feed tank and drop tank supernate solutions modeled at $140^{\circ} \mathrm{C}$ with and without simulated evaporation are not saturated with respect to NAS.

- A safe operational strategy is to determine the supersaturation of the feed tank supernate with respect to the NAS at $40^{\circ} \mathrm{C}$ : an unsaturated tank supernate feed will not precipitate in the evaporator at $140^{\circ} \mathrm{C}$ (at specific gravities of 1.4-1.6 $\mathrm{g} / \mathrm{cc})$. 


\subsection{RECOMMENDATIONS}

The following recommendations from this study should be implemented as soon as feasible:

- The feed pump should always be located $>20$ " above the "Zone of Turbidity" which is $\sim 40$ " above the sludge layer

- Routine analytic samples, if used for confirmatory modeling, must be taken at the height of the feed pump

- Analytic samples should not be taken within 5-6 hours of tank transfers and/or recent tank recycles

- The evaporator should not be fed within 5-6 hours of tank transfers and/or recent tank recycles

- A more accurate Si analysis method must be implemented in the F-Area laboratory immediately

- A recent (after September 2000) Tank 32 sample should be analyzed immediately by a more accurate $\mathrm{Si}$ analysis method to ensure that the $3 \mathrm{H}$ Evaporator solutions are not moving into the stability field of NAS gel precipitation

- The drop tank transfer jet must be moved to a higher position in the drop tank to avoid recycling precipitated $\mathrm{Fe}(\mathrm{OH})_{3}$ and/or silica sol deposits, and/or entrained sludge solids back to the feed tank (Completed Spring 2001).

- Inject recycle from Tank 30 above the sludge layer in Tank 32 and not subsurface to minimize the "Zone of Turbidity" caused by tank transfers and maximize settling of suspended solids and silica sols

It is desirable that the following recommendations be considered as a longer term strategy:

- Eliminate recycle directly from Tank 30 to the feed tank (Tank 32): use Tanks 39 and/or Tank 35 as settling tanks so that NAS supersaturation and accumulation of silica sol deposits is no longer a concern 


\subsection{ACKNOWLEDGEMENTS}

Dr. W. J. Frederick of the Institute of Paper Science and Technology is gratefully acknowledged for the usage of his unpublished data on the solubility of hydroxysodalite and Zeolite-A.

Kent Gilbreath from the SRS H-Area Tank farm is thanked for providing the data about sludge levels, feed pump levels, and operating temperatures of the SRS $3 \mathrm{H}$ from the Tank Farm morning reports. Ken Jones of the F-Area laboratory is acknowledged for discussions about the F-Area Si analytic methodology and dilution factors.

Many helpful suggestions and discussions with Jeff Pike of SRS are acknowledged. Most notable of his many contributions was assistance in gathering the solubility data for $\mathrm{NaAlO}_{2}$ and $\mathrm{AlO}_{2}^{-2}$ so that these species could be adequately represented on the activity diagrams.

This work was performed under contract No. DE-AC09-96SR18500 with the Department of Energy and co-funded by the Tank Focus Area under Technical Task Plan \# SR-1-9WT-31. 


\subsection{REFERENCES}

1 W. R. Wilmarth, C. J. Coleman, A. R. Jurgensen, W. M. Smith, J. C. Hart, W. T. Boyce, D. Missimer, C. M. Conley, "Characterization and Dissolution Studies of Samples from the 242-16H Evaporator,' WSRC-TR-2000-00038, Rev. 0 (January 31, 2000).

2 W. R. Wilmarth, C. J. Coleman, J. C. Hart, and W. T. Boyce, "Characterization of Samples from the 242-16H Evaporator Wall," WSRC-TR-2000-00089 (March 20, 2000).

3 C.M. Jantzen and J.E. Laurinat, "Thermodynamic Modeling of the SRS Evaporators: Part I. The 2H and 2F Systems (U)," WSRC-TR-2000-00293 (May, 2001).

4 W. R. Wilmarth, S. D. Fink, D. T. Hobbs, M. S. Hay, "Characterization and Dissolution Studies of Samples from the 242-16H Evaporator Gravity Drain Line,"WSRC-TR-97-0326, Rev.0 (October 16, 1997).

5 R.M. Garrels, “Geology,” Section 6 in Atllas of Electrocemical Equilibria in Aqueous Solutions, National Association of Corrosion Engineers, Houston, TX, (English Translation), 89-94 (1966).

6 T. S. Bowers, K. J. Jackson, and H. C. Helgeson, "Equilibrium Activity Diagrams for Coexisting Minerals and Aqueous Solutions at Pressures and Temperatures to $5 \mathbf{k b}$ and $\mathbf{6 0 0}^{\circ} \mathbf{C}$," Springer-Verlag, New York, 397pp. (1984).

7 R. M. Garrels and C. L. Christ, "Solutions, Minerals, and Equilibria," Harper \& Row, New York, 450pp. (1965).

8 K. V. Ragnarsdottir, "Dissolution Kinetics of Heulandite at pH 2-12 and $\mathbf{2 5}^{\circ}$ C," Geochimica et Cosmochimica Acta, 57, 2439-2449 (1993).

9 T. S. Bowers and R. G. Burns, "Activity Diagrams for Clinoptilolite: Susceptibility of this Zeolite toFurther Diagenetic Reactions," American Mineralogist, 75, 601-619 (1990).

10 C. M. Jantzen and J.B. Pickett, "Vitrification of M-Area Mixed (Hazardous and Radioactive) Wastes: I. Sludge and Supernate Characterization," WSRC-TR-94-0234 (September, 2001). Earlier report with fewer tank analyses published as DPST-89-351 (March 1, 1989).

11 R. Pierce, WSRC-NB-2000-00054 (June 14, 2000). 
12 E.S. Dana, “A Textbook of Mineralogy,” John Wiley \& Sons, Inc., New York, 851pp (1932).

13 W. A. Deer, R. A. Howie, and J. Zussman, "Rock-Forming Minerals, Vol IV," John Wiley \& Sons, Inc., New York, 435pp. (1963).

14 W. Sinkler, T.P. O’Holleran, S.M. Frank, M.K. Richmann, S.G. Johnson, "Characterization of A Glass-Bonded Ceramic Waste Form Loaded with U and Pu," Scientific Basis for Nuclear Waste Management, XXIII, R.W. Smith and D.W. Shoesmith (Eds.), Materials Research Society, Pittsburgh, PA, 423-429 (2000) and T. Moschetti, W. Sinkler, T. Disanto, M.H. Hois, A.R. Warren, D. Cummings, S.G. Johnson, K.M. Goff, K.J. Bateman, S.M. Frank, "Characterization of a Ceramic Waste Form Encapsulating Radioactive Electrorefiner Salt," Scientific Basis for Nuclear Waste Management, XXIII, R.W. Smith and D.W. Shoesmith (Eds.), Materials Research Society, Pittsburgh, PA, 577-582 (2000).

15 Wilmarth, personnel communication

16 W.J. Frederick, personal communication

17 H. A. Gasteiger, W. J. Frederick, and R. C. Streisel, "Solubility of Aluminosilicates in Alkaline Solutions and a Thermodynamic Equilibrium Model,’ Ind. Eng. Chem. Res., 31, 1183-1190 (1992).

18 R. M. Milton, U.S. Patents \#2,882,243 and \#2,882,244 (1959)

19 Kirk-Othmer Encyclopedia of Chemistry, Vol. 16 (1995).

20 R. M. Barrer, J. W. Baynham, F. W. Bultitude, and W. M. Meier, "Hydrothermal Chemistry of the Silicates. Part V23I, Low-Temperature Crystal Growth of Aluminosilicates, and of Some Gallium and Germanium Analogues," 195-208 (1959).

21 R.M. Barrer, "Hydrothermal Chemistry of Zeolites," Academic Press,London (1982).

22 T. Ejaz A.G. Jones and P. Graham, "Solubility of Zeolite-A and Its Amorphous Precursor Under Synthesis Conditions,” J. Chem. Eng. Data, 44, 574-576 (1999).

23 The American Heritage Dictionary, Second College Edition, Houghton Mifflin Co., Boston, MA, (1982).

24 G.M. Barrow, "Physical Chemistry," 2nd edition, McGraw-Hill Book Company, New York, 843pp., (1966). 
25 M.C. Barnes, J.A. Mensah, and A.R. Gerson, "The Mechanism of the Sodaliteto-Cancrinite Phase Transformation in Synthetic Spent Bayer Liquor," Microporous and Mesoporous Materials, 31, 287-302 (1999).

26 A.R. Gerson and K. Zheng, "Bayer Process Plant Scale: Transformation of Sodalite to Cancrinite," J. of Crystal Growth, 171, 209-218 (1997).

27 J.C. Buh. And J. Lons, "Synthesis and Crystal Structure of Nitrate Enclathrated Sodalite, $\mathrm{Na}_{8}\left[\mathrm{AlSiO}_{4}\right]_{6}\left(\mathrm{NO}_{3}\right)_{2}$," Journal of Alloys and Compounds, v.235, 41-47 (1996).

28 W. R. Wilmarth, D. D. Walker, S. D. Fink, "Sodium Aluminosilicate Formation in Tank 43H Simulants,” WSRC-TR-97-00389, Rev. 0 (November 15, 1997).

29 B. Subotic, D. Skrtic, I. Smit, L. Sekovanic, "Transformation of Zeolite-A into Hydroxysodalite,’ J. Crystal Growth, 50, 498-508 (1980). Microcrystals; Part I. Influence of the Alkalinity of the System on the Growth of Zeolite-A Microcrystals," Microporous and Misoporous Materials, 28, 483-493 (1999).

31 D. W. Breck, W. G. Eversole, R. M. Milton, T. B. Reed, and T. L. Thomas, "Crystalline Zeolitesl I. The Properties of a New Synthetic Zeolite, Type A," J. Am. Chem. Soc., 78 [23], 5963-5971 (1956).

32 J. Maly and V. Vesely, “A Contribution to Sodium Polyuranate Chemistry,” J. Inorg. Nucl. Chem., 7, 119-128 (1958).

33 J. E. Ricci and F. J. Loprest, "Phase Relations in the System Sodium OxideUranium Trioxide-Water at 50 and $\mathbf{7 5}^{\circ}$ C," J. Am. Chem. Soc., 77, 2119-2129 (1955).

34 C. A. Wamser, J. Belle, E. Bernsohn and B. Williamson, "The Constitution of the Uranates of Sodium,” J. Am. Chem. Soc, 74, 1020-1022 (1952).

35 D. T. Hobbs and D. G. Karraker, "Recent Results on the Solubility of Uranium and Plutonium in Savannah River Site Waste Supernate," Nuclear Technology, 114, 318-324 (1996).

36 W.R. Wilmarth and R.A. Peterson, "Analyses of Surface and Variable Depth Samples from Tanks 30H and 32H,” WSRC-TR-2000-00112 (April, 2000). 
37 W.R. Wilmarth, J.T. Mills, V.H. Dukes, C.J. Coleman, J.C. Hart, W.T. Boyce, and R.L. Cadle, "Characterization of Samples from the 3H Evaporator System Including Effects of Recycle,” WSRC-TR-2000-00399 (October, 2000).

38 W.R. Wilmarth, “Tank 30H Sample Analysis Results," SRT-LWP-2000-00191 (January 10, 2001).

39 D.D. Walker and C.J. Coleman, "Densities and Weight\% Solids of Simulated Salt Solutions," WSRC-TR-91-176 (April 1991).

40 C. Coleman, personal communication

41 R.K. Iler, "The Colloid Chemistry of Silica and Silicates," Cornell University Press, Ithaca, NY, 324pp. (1955).

42 A.K. Varshneya, "Fundamentals of Inorganic Glasses," Academic Press, Inc., New York, 570pp. (1994).

C.F. Baes, Jr. and R.E. Mesmer, "The Hydrolysis of Cations,” John Wiley \& Sons, New York, 489pp. (1976).

S. Sjoberg, L.Ohman, N. Ingri, "Equilibrium and Structural Studies of Silicon(IV) and Aluminum(III) in Aqueous Solution. 11. Polysilicate Formation in Alkaline Aqueous Solution. A Combined Potentiometric and 29Si NMR Study," Acta Chemica Scandinavica, A39, 93-107 (1985).

45 I. Grenthe, et. al., "Chemical Thermodynamics of Uranium," North Holland, New York (1992).

R.H. Busey, R.E. Mesmer, "Inoization Equilibria of Silicic Acid and Polysilicate Formation in Aqueous Sodium Chloride Solutions to $300^{\circ}$ C," Inorg. Chem., 16, 2444-2450 (1977).

47 A.S. Russell, J.D. Edwards, and C.S. Taylor, "Solubility and Density of Hydrated Aluminas in NaOH Solutions,' J. of Metals, p.1123-1128 (October, 1955).

48 D.A. Reynolds and D.L. Herting, "Solubilities of Sodium Nitrate, Sodium Nitrite, and Sodium Aluminate in Simulated Nuclear Waste," U.S. DOE Report, RHO-RE-SST-14P, Westinghouse Hanford Company, Richland, WA (September, 1984).

49 H. Park and P. Englezos, "Thermodynamic Modeling of Sodium Aluminosilicate Formation in Aqueous Alkaline Solutions,' Ind. Eng. Chem. Res., 38, 4959-4965 (1999). 
WSRC-TR-2001-00155, Rev. 1

50 T.J. Wolery, “EQ3NR, A Computer Program for Geochemical Aqueous Speciation-Solubility Calculations: Theoretical Manual, User's Guide, and Related Documentation (Version 7.0)," U.S. DOE \#UCRL-MA-110662, Pt. III, Lawrence Livermore National Laboratory, Livermore, CA (September 14, 1992).

$51 \quad$ R.A. Peterson and R.A. Pierce, "Sodium Diuranate and Sodium Aluminosilicate Precipitation Test Results,” WSRC-TR-2000-00156 (May 15, 2000). 